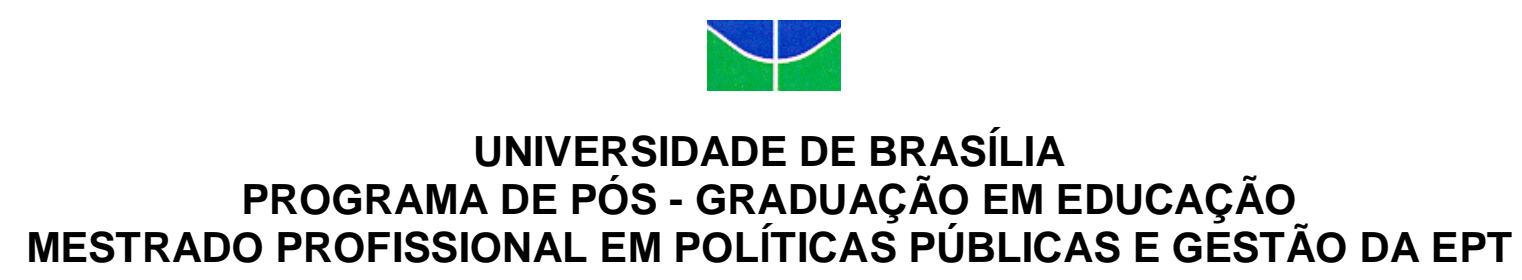

JOEDNA LOBATO DO AMARAL HÜBNER

O MODELO DE GESTÃO APLICADO AO ENSINO NO IFPI FRENTE ÀS CONFIGURAÇÕES DOS IFS

BRASÍLIA - DF 


\title{
O MODELO DE GESTÃO APLICADO AO ENSINO NO IFPI FRENTE ÀS CONFIGURAÇÕES DOS IFS
}

\author{
Dissertação apresentada ao Programa de \\ Pós-Graduação em Educação Profissional da \\ Faculdade de Educação da Universidade de \\ Brasília, como parte dos requisitos para \\ obtenção do título de Mestre em Educação \\ área de Políticas Públicas e Gestão para \\ Educação Profissional Tecnológica. \\ Área de Concentração: Educação \\ Linha de pesquisa: Políticas Públicas e \\ Gestão para EPT. \\ Orientador: Prof. Dr. Bernardo Kipnis \\ Faculdade de Educação da UnB
}

Brasília - DF 
Ficha catalográfica elaborada automaticamente, com os dados fornecidos pelo(a) autor(a)

L

Lobato do Amaral Hübner, Joedna

O MODELO DE GESTÃO APLICADO AO ENSINO NO IFPI

FRENTE ȦS CONFIGURAÇÕES DOS IFs / Joedna Lobato do

Amaral Hübner; orientador Bernardo Kipnis. --

Brasilia, 2015.

$133 \mathrm{p}$.

Dissertaçåo (Mestrado - Mestrado Profissional em Educaçăo) - - Universidade de Brasília, 2015.

1. Modelo de geståo do Ensino. 2. Educaçåo Profissional Tecnológica . 3. Instituto Federal de Educaçăo, Ciência e Tecnologia . 4. Política Pública. I. Kipnis, Bernardo, orient. II. Título. 


\section{Universidade de Brasília}

Faculdade de Educação

Joedna Lobato do Amaral Hübner. O modelo de gestão aplicado ao ensino no IFPI frente às configurações dos IFs

Dissertação apresentada ao Programa de Pós-Graduação em Educação - Mestrado Profissional em Políticas Públicas e Gestão para EPT da Faculdade de Educação - UnB.

Área de Concentração: Educação

Linha de pesquisa: Políticas Públicas e Gestão para EPT.

Orientador: Prof. Dr. Bernardo Kipnis

Faculdade de Educação da UnB

Aprovada pela banca examinadora constituída pelos professores:

Prof. Dr. Bernardo Kipnis - FE/ UNB - Orientador

Prof. Dr. Remi Castioni - FE/ UNB - Examinador

Prof. ${ }^{a}$ Dr ${ }^{a}$. Maria Cristina Madeira da Silva - IFB - Examinadora

Aprovado em, 18/12/2015. 
À Deus autor e Senhor da minha vida, à minha família alicerce forte e necessário, para não sucumbir ás dificuldades do caminho. 


\section{AGRADECIMENTOS}

Em primeiro lugar agradeço a Deus, pela vida, por essa valiosa oportunidade de aprendizado, enfim, por tudo, pois sem Ele nada posso fazer.

Como agradecer minha família, que esteve comigo em todos os instantes dessa empreitada? O que dizer ao meu pequeno João Alexandre, companheiro de mestrado desde do ventre, quando participei da última etapa da seleção ele estava com 36 semanas, prontinho para nascer. E nas primeiras aulas, com dias de nascido, esperava a mamãe sair da aula para amamentar e a fome era tamanha que recorria ao dedo para tentar enganá-la, instintos de sobrevivência, que só o ser humano possui. Obrigada meu anjinho, pela disposição. Ao meu marido Alexandre, minha gratidão, meu amor e meu reconhecimento, pois foi um incentivador, um suporte emocional, com apoio irrestrito nas obrigações com os nossos filhos e nas questões do dia a dia. A minha princesa Ester, uma filha doce e compreensiva, que não só entendia a ausência da mamãe, mas disfarçava a saudade, só para não me deixar preocupada. A minha querida mãe Dona Edmar Lobato, um obrigado carinhoso e sincero, pelas idas e vindas a Brasília, para cuidar do pequeno João Alexandre, nos períodos das aulas. Agradeço ainda, minha irmã Joane, minha sogra Rosaly, pelo desprendimento em ajudar nos momentos difíceis.

Não poderia deixar de agradecer as amigas Ana Joséfa, Ana Elízia, Leomara, Leonice e Dona Leonor, por abrirem as portas de suas casas e me receberem em Brasília, com todo carinho. Considero-as anjos de Deus em minha vida.

Aos colegas de turma, alguns verdadeiros amigos, obrigada pela cumplicidade, por compartilhar de experiências, saberes e pelas alegrias que marcaram para sempre ás nossas vidas.

Meus mestres, doutores do saber, não posso dimensionar minha gratidão, pois não só contribuíram para minha formação, mas me transformaram em ser humano melhor, mais capacitado e com uma visão diferente do mundo. Quero destacar meu orientador Prof. Dr. Bernardo Kipnis, que com seu jeito sério e exigente, me deu suporte necessário para ser mais criteriosa, na busca pela qualidade da dissertação. Mesmo quando estava do outro lado do mundo, lá na Austrália, não se se tornou ausente no andamento da pesquisa. 
Agradeço a SETEC/ MEC, pelo convênio firmado com a UNB, talvez sem o qual eu nunca teria cursado a pós-graduação em uma instituição tão séria e tão reconhecida nacionalmente, pela qualidade de seus programas.

Ao IFPI, em especial a Pró- Reitoria de Ensino, por me receber na sede da reitoria e por autorizar a realização da pesquisa. Ao Campus Corrente, na pessoa dos gestores, por viabilizarem meus estudos, compreendendo e permitindo as ausências constantes, por conta das exigências do curso e ainda agradeço a autorização para a realização da pesquisa. Em especial, agradeço ao coordenador do curso de Licenciatura em Matemática do IFPI - Campus Corrente, Prof. Mestre Flávio de Ligório, pois se envolveu nos meus estudos, me dando orientações de referências bibliográficas, além de se ocupar em ler minhas produções.

Estendo os agradecimentos à banca examinadora pela disponibilidade em avaliar meu trabalho e de já agradeço às contribuições vindouras.

É impressionante como não fazemos nada sozinhos e agradecer é um gesto simples, porém é a melhor maneira de reconhecer o que nos foi feito de bom. Obrigada a todos e todas! 


\section{RESUMO}

O objetivo geral desta pesquisa foi analisar a gestão aplicada ao ensino no IFPI, o qual se constitui num exemplo quanto às finalidades e características dos IFs. De acordo com os objetivos específicos, buscou-se identificar as limitações e os desafios da gestão da PROEN (Pró-Reitoria de Ensino) e DIREN (Direção de Ensino), no atendimento às diversas modalidades e verticalização do ensino e como ocorre a articulação com as demandas sociais e as peculiaridades regionais. Coube examinar como a PROEN estabelece, acompanha e avalia as ações articuladas ao processo ensino-aprendizagem desenvolvidas na DIREN - Campus Corrente e verificar as ações desenvolvidas pela gestão de ensino, para constituir-se em centro de excelência na oferta do ensino e ainda ações que contemplem os docentes em busca da qualidade do ensino no IFPI. Partindo de um referencial teórico que aborda as questões de modelo aplicado à gestão, foram estudadas as contribuições históricas na evolução da administração pública no Brasil, a conceituação de política pública e seu ciclo, bem como a caracterização dos IFs e seus modelos de gestão e de gestão do ensino. Por meio da pesquisa qualitativa, foram utilizados para coleta de dados os procedimentos técnicos de leitura de documentos, observação não-participante, grupo focal, entrevistas e questionários abertos. Para análise de dados, foi utilizado o método de categorização de Bardin (2011), com a utilização do software WELF QDA para sua tabulação e organização em categorias. Foi constatado que o modelo de gestão aplicado ao ensino no IFPI apresenta algumas fragilidades quanto a algumas características dos IFs, no sentido da verticalização, das várias modalidades de ensino ofertadas, a falta de sintonia do planejamento com os arranjos produtivos locais, a dificuldade da Pró-Reitoria de Ensino em monitorar e acompanhar as ações de ensino nos campi, e dificuldade de comunicação entre Pró-Reitoria e o campus e vice-versa, além de outros pontos relevantes. O produto técnico consiste na criação de um ambiente virtual, denominado AVGE - Ambiente Virtual de Gestão do Ensino, que tem como objetivo principal auxiliar a PROEN e a DIREN no monitoramento das ações e projetos de ensino em tempo real. Conclui-se que o IFPI apresenta um modelo de gestão de ensino único, no contexto do Campus Corrente, mas que necessita de ajustes para atender com êxito as características e finalidades dos IFs.

Palavras-chave: Modelagem, Gestão, Ensino, Educação Profissional e Tecnológica, Institutos Federais. 


\begin{abstract}
The overall objective of this research was to analyze the management applied to education in the IFPI, which constitutes an example as to the purposes and characteristics of the IFs. According to the specific objectives, it sought to identify the limitations and challenges of managing PROEN (Pro Teaching Rectory) and DIREN (Educational Department), in meeting the diverse forms and verticalization of teaching and how the articulation with social demands and regional peculiarities occurs. It fell examine how PROEN establishes, monitors and evaluates the actions articulated to the learning process developed in DIREN - Campus Corrente and verify the actions taken by the teaching management, to form themselves into a center of excellence in the teaching offer and still contemplate the teachers in search of quality of education in IFPI. Starting from a theoretical referential that addresses the issues of the model applied to the management, the historical contributions in the evolution of public administration in Brazil were studied, the concept of public policy and its cycle as well as the characterization of IFs and their management models and teaching management. Through qualitative research were used to data collect the technical procedures for reading documents, non-participant observation, focus group, interviews and open questionnaires. For data analysis, we used the method of categorization of Bardin (2011), using the WELF QDA software for tabulation and organization in categories. It was found that the management model applied to the teaching in the IFPI has some weaknesses as some characteristics of Fls, towards in the verticalization of the various types of teaching offered, the lack of tune in planning with the local clusters, the difficulty of the Pro Teaching Rectory to monitor and track the teaching actions on campuses, and difficulty of communication between the Pro Rectory and the campus and vice versa, and other relevant points. The technical product consists in the creation of a virtual environment, called AVG is - Virtual Environment for teaching Management, which aims to assist PROEN and DIREN in monitoring activities and teaching projects in real time. We conclude that the Fls introduce a unique teaching management model, in the context of the Corrente Campus, but needs adjustments to meet successfully the characteristics and purposes of Fls.
\end{abstract}

Keywords: Modeling, Management, Teaching, Professional and Technological Education, Federal Institutes 


\section{LISTA DE FIGURAS}

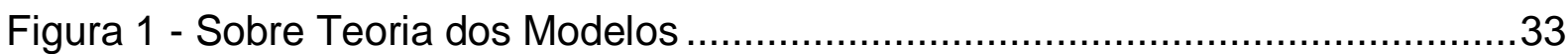

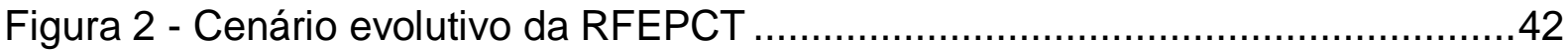

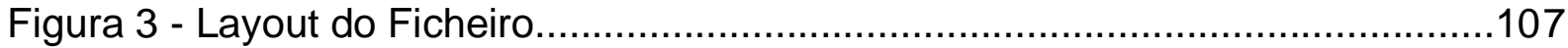

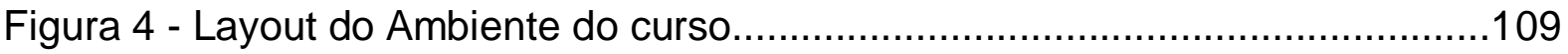

Figura 5 - Layout do Ambiente do Feedback......................................................110

Figura 6 - Layout do Fórum.....................................................................111 


\section{LISTA DE QUADROS}

Quadro 1 - Fases da Educação Profissional no Brasil.............................................34

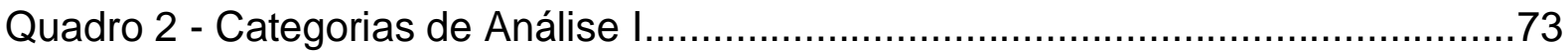

Quadro 3 - Estrutura Organizacional da PROEN (IFPI) ......................................74

Quadro 4 - Estrutura Organizacional da DIREN (IFPI) .......................................

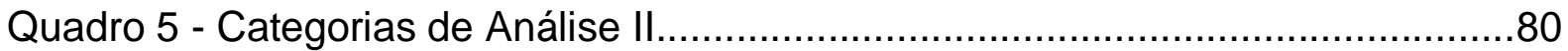

Quadro 6 - Resumo das finalidades e características do IFs....................................83

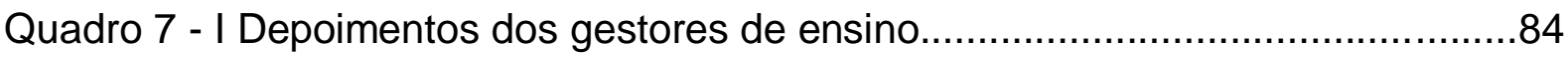

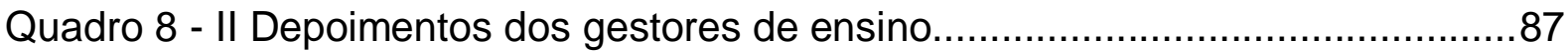

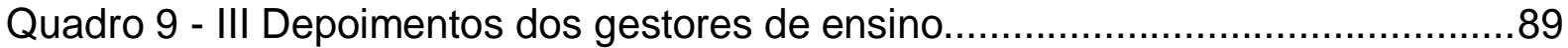

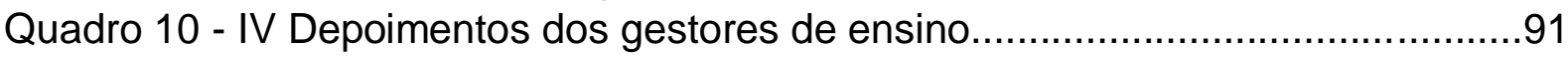

Quadro 11 - V Depoimentos dos gestores de ensino...........................................94

Quadro 12 - VI Depoimentos dos gestores de ensino..........................................96

Quadro 13 - VII Depoimentos dos gestores de ensino..........................................98

Quadro 14 - VIII Depoimentos dos gestores de ensino........................................100 


\section{LISTA DE ABREVIATURAS E SIGLAS}

AVGE - Ambiente Virtual de Gestão do Ensino

BID - Banco Interamericano de Desenvolvimento

CEFETs - Centro Federal de Educação Tecnológica

CPAs - Comissões Próprias de Avaliação

DIREN - Direção de Ensino

EAD - Educação à Distância

EJA - Educação de Jovens e Adultos

EPT - Educação Profissional Tecnológica

FHC - Fernando Henrique Cardoso

FIC - Formação Inicial e Continuada

FMI - Fundo Monetário Internacional

IES - Instituição de Ensino Superior

IFET - Instituto Federal de Educação Tecnológica

IFPI - Instituto Federal de Educação, Ciência e Tecnologia do Piauí

IFs - Institutos Federais

INEP - Instituto Nacional de Estudos e Pesquisas Educacionais Anísio Teixeira

JK - Juscelino Kubitschek

LDB - Lei de Diretrizes e Bases da Educação Nacional

OD - Organização Didática

OMC - Organização Mundial do Comércio

PDE - Plano de Desenvolvimento da Educação

PDI - Plano de Desenvolvimento Institucional

PEE - Plano Estadual de Educação

PI - Piauí

PME - Plano Municipal de Educação

RE - Regimento Interno

PROEN - Pró - Reitoria de Ensino

PROEP - Programa de Expansão da Educação Profissional

RFEPCT - Rede Federal de Educação Profissional, Científica e Tecnológica

SETEC - Secretaria de Educação Profissional Tecnológica

TCU - Tribunal de Contas da União 
TICs - Tecnologias da Informação e Comunicação

UNEDs - Unidades decentralizadas

UNESCO - Organização das Nações Unidas para a Educação, a Ciência e a Cultura 


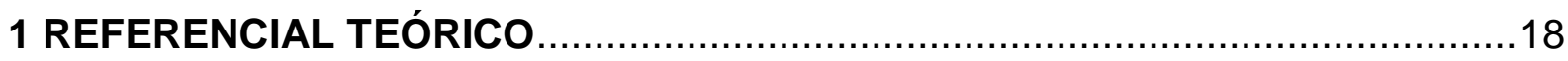

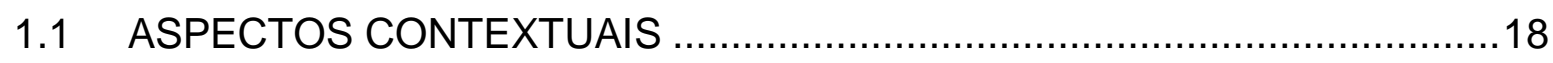

1.1.1 Percurso histórico da Gestão Pública ..............................................18

1.1.2 Repercussões das mudanças de gestão pública na gestão

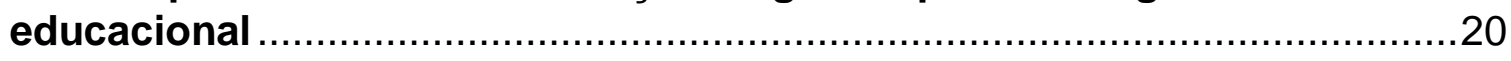

1.1.2.1 Políticas Públicas: Ações Governamentais.......................................23

1.1.3 Considerações sobre o modelo de Gestão das Universidades

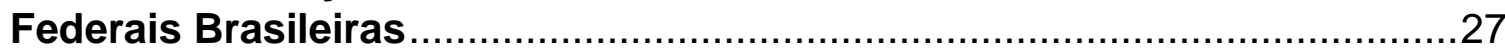

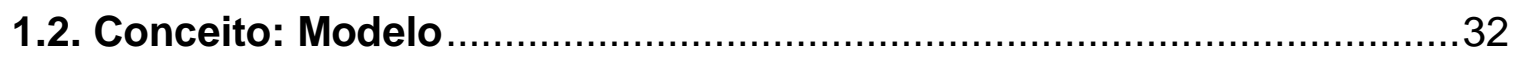

2.1 EDUCAÇÃO PROFISSIONAL, CIENTÍFICA E TECNOLÓGICA NO BRASIL:

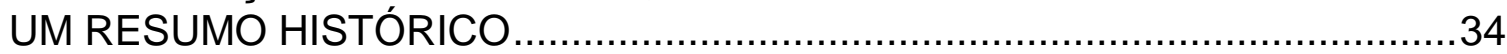

2.1.1 Configurações dos Institutos Federais de Educação, Ciência e

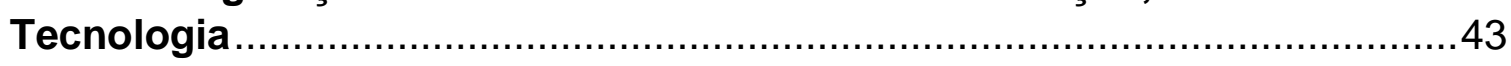

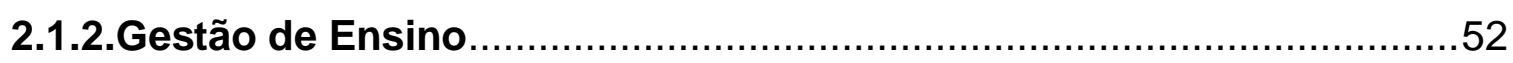

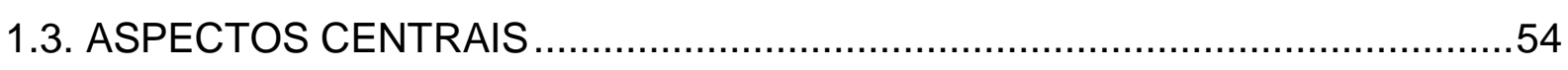

1.3.1. Modelo de Gestão dos IFs

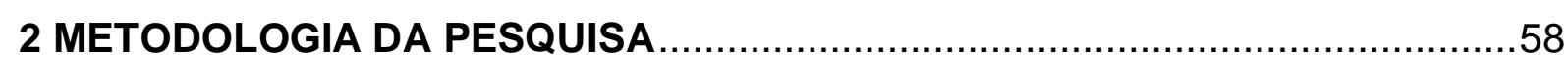

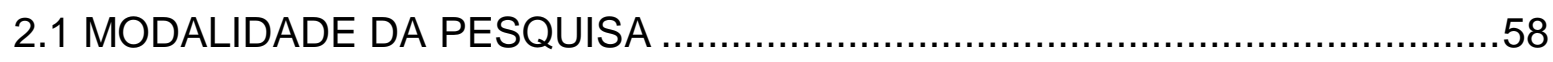

2.2 O QUE DIZEM OUTRAS PESQUISAS SOBRE MODELOS DE GESTÃO DO

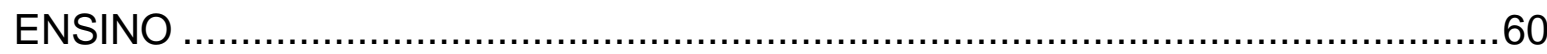

2.2.2 Gestão da área educacional - características.....................................63

2.3. IDENTIFICAÇÃO DO CAMPO DA PESQUISA E SEUS SUJEITOS -

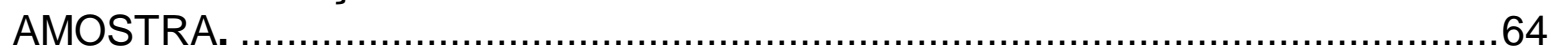

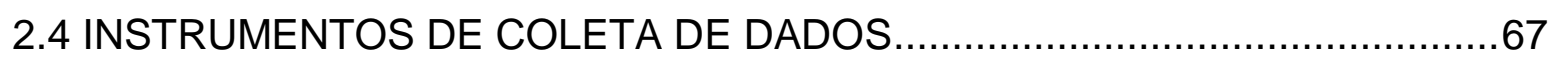

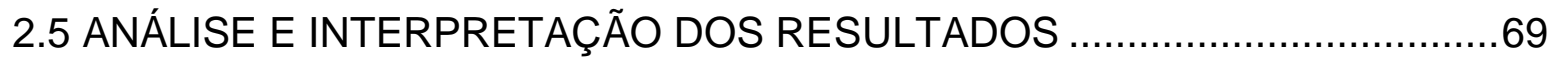

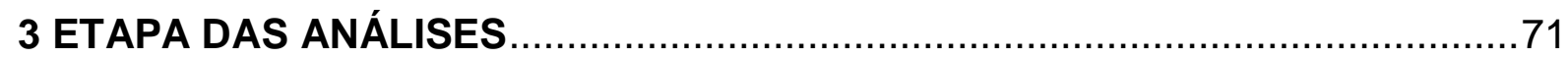

3.1 ANÁLISE DOCUMENTAL E OBSERVAÇÃO NÃO PARTICIPANTE ................71

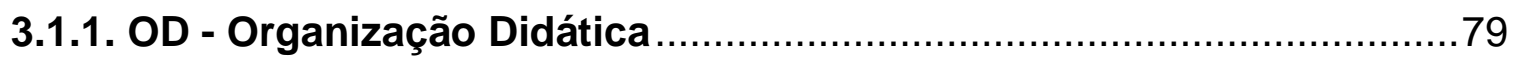

3.2 GESTÃO DE ENSINO NA PERCEPÇÃO DOS GESTORES E DOS

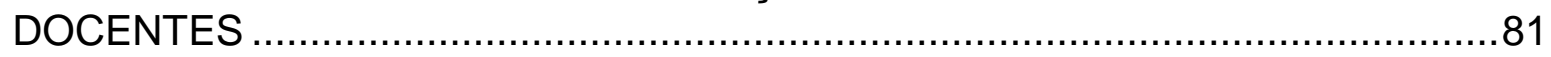

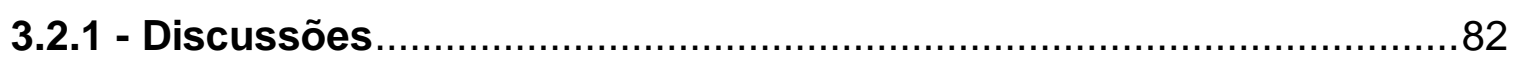

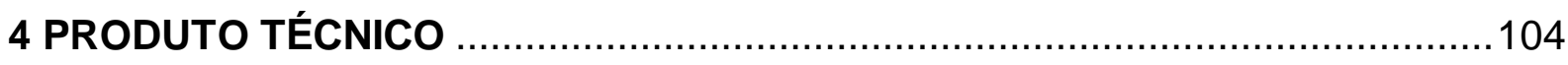

4.1 INTRODUÇÃO

4.2 DESCRIÇÃO DO PRODUTO TÉCNICO.....................................................105

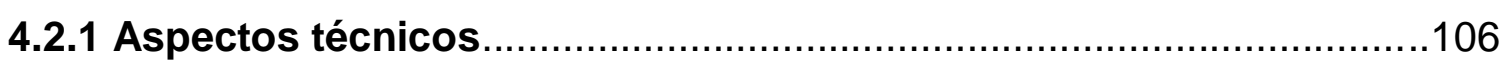


6 REFERÊNCIAS BIBLIOGRÁFICAS

APÊNDICE A TERMO DE CONSENTIMENTO DOS SUJEITOS

APÊNDICE B CONVITE.

APÊNDICE C TERMO DE CONSENTIMENTO DOS SUJEITOS II.

APÊNDICE D TERMO DE CONSENTIMENTO DOS SUJEITOS III. 129

APÊNDICE E QUESTIONÁRIO ABERTO 130

APÊNDICE F ROTEIRO DA OBSERVAÇÃO 131

APÊNDICE G ROTEIRO DE ENTREVISTA PRÓ-REITORA DE ENSINO 132 APÊNDICE H ROTEIRO DE ENTREVISTA DIRETORA DE ENSINO 


\section{INTRODUÇÃO}

Como docente do IFPI (Instituto Federal de Educação, Ciência e Tecnologia do Piauí), Campus Corrente, desde 2009, desempenhei algumas funções correlacionadas à gestão, dentre elas a Direção de Ensino do IFPI - Campus Corrente. Foi uma experiência inédita por dois motivos. Em primeiro lugar, não sabia nada de educação profissional, nunca tinha trabalhado com formação de trabalhadores. Outro motivo, residia na falta de experiência em direção de escola. Enquanto diretora, percebi a complexidade da instituição, não só porque abarcava várias modalidades e níveis educacionais, mas pela filosofia de ser um centro de formação profissional de excelência articulado com as demandas regionais, um aspecto que representava as políticas de extensão e ainda havia o apelo tecnológico, com estímulo à produção científica representando outro aspecto institucional, o de incentivo à pesquisa.

Neste contexto, tão amplo e tão ligado a outros segmentos, a inquietação no período era delimitar o campo de atuação da Direção de Ensino. Qual o papel da Direção de Ensino em um campus de um Instituto Federal? Tal questionamento se fazia ainda mais presente, quando me via, muitas vezes, dedicando horas a fio aos aspectos burocráticos da gestão, que consistia em responder memorandos da PróReitoria de Ensino, fazer relatórios, levantamentos de necessidades, enfim aspectos burocráticos. As outras horas passava resolvendo demandas do Ensino Médio, que é o nível de ensino em que percebo receber mais atenção da gestão, talvez pela peculiaridade dos alunos, por passar mais tempo na instituição, ou pelo fato de ser o público maior no nosso Instituto. Ainda pairava a dúvida, de como o ensino se articularia com a extensão e a pesquisa no sentido de favorecer a aprendizagem. Só que, a realidade não permitia fazer muitas reflexões, pois a todo momento era uma situação nova que precisava de direcionamento, de articulação e exigia soluções, que deveriam vir rapidamente.

Devido à minha atuação na Direção de Ensino surgiu o interesse em fazer dela, um objeto de pesquisa, investigação, sem desconsiderar a relação com a PróReitoria de Ensino do IFPI e os aspectos institucionais. 
O objetivo geral deste trabalho é analisar a gestão aplicada ao ensino no IFPI, o qual se coloca como um exemplo que nos permitirá evidenciar as finalidades e características dos IFs e ainda, objetivando especificamente, identificar as limitações e os desafios da gestão da PROEN (Pró-Reitoria de Ensino) e DIREN (Direção de Ensino), no atendimento às diversas modalidades de ensino, observar como a gestão de ensino age para atender às demandas sociais e as peculiaridades regionais, investigar as dificuldades da gestão de ensino, no âmbito da PROEN e DIREN Campus Corrente, quanto à verticalização do ensino, reconhecer as ações da gestão de ensino do IFPI para constituir-se em centro de excelência no ensino, examinar como a PROEN estabelece, acompanha e avalia as ações articuladas ao processo ensino-aprendizagem desenvolvidas na DIREN - Campus Corrente e examinar as ações desenvolvidas pela gestão de ensino que contemplam os docentes em busca da qualidade do ensino no IFPI. Todos os objetivos propostos visam buscar respostas para a seguinte questão: O modelo de gestão, aplicado ao ensino no IFPI contempla com êxito às finalidades e características dos IFs?

Foi considerado o modelo de gestão aplicado ao ensino do IFPI a PróReitoria de Ensino (PROEN) e sua estrutura organizacional, a qual realiza a gestão em contexto macro, direcionando as políticas de ensino em 20 campi deste Instituto Federal e a Direção de Ensino do Campus Corrente, a qual se responsabiliza pela gestão de ensino local.

Ao estudar a gestão, foi necessário fazer um recorte histórico sobre a administração pública no Brasil, sua evolução e os seus princípios atuais. Considerando a tipologia da administração pública, destaca-se uma sequência saindo da Administração Pública Patrimonialista, Administração Burocrática, culminando com a Gestão Pública-Gerencial, que é mais recente. Dialogando com Junquilho (2012) e Bresser (2006), foi possível perceber que os modelos assumidos no país tinham forte influência internacional, com destaque para a nova gestão pública.

Nos anos de "1980 inicia-se uma grande revolução na administração pública dos países centrais em direção a uma administração pública gerencial", (BRESSER, 2006, p.5). A nova gestão pública, baseia-se nos critérios de eficiência, de eficácia e de produtividade, seguindo a referência do modelo empresarial, descentralizado, com ênfase no cliente, segundo Araújo e Castro (2011).

No contexto educacional, os modelos de gestão pública também influenciaram a forma de conduzir a escola. 
Os modelos permitem uma tentativa de visualização do conhecimento. Não só na ciência como também no mundo organizacional os modelos são uma representação da realidade que pode ser então explicada matematicamente e por meio de diagramas e gráficos. (CAMPOS, 2009, p.53).

Atualmente o modelo gerencial tem sido adotado devido à busca pela qualidade, eficiência e eficácia e tem se materializado em medidas que favorecem a maior participação da comunidade escolar nas decisões e na escolha dos gestores. No modelo gerencial, há um investimento na capacitação dos gestores e na elaboração de documentos que conduzem a escola a planejamentos estratégicos para melhorar o desempenho de suas atividades.

As mudanças mais significativas na instituição escolar não ocorrem dentro da escola e sim no contexto macro da educação, a nível de decisões governamentais, impulsionadas por políticas públicas que impactam todo o sistema educativo.

A política pública é um instrumento de intervenção, um mecanismo de atuação do Estado frente às demandas sociais, de forma sistematizada. É um campo multidisciplinar com foco nas explicações, um problema ou carência e nas "interrelações entre Estado, política, economia e sociedade" (SOUZA, 2006), para elaborar mecanismos de intervenção na realidade, com ações que provoquem mudanças. Toda política pública tem um ciclo.

Em sua forma clássica o círculo de formulação e avaliação de políticas
públicas é composto pelas etapas de Diagnóstico, Formulação,
Implementação e Avaliação. Cada etapa desse ciclo envolve um conjunto de
indicadores de diferentes naturezas e propriedades em função das
necessidades intrínsecas das atividades nelas envolvidas (JANUZZI, 2005,
p.03).

Justifica-se o estudo conceitual de política pública efetuado neste trabalho porque, ao estudar o modelo de gestão de ensino aplicado ao IFPI, faz-se referência a uma instituição modificada por uma lei, qual seja, a Lei Federal no 11892 de 2008, o que corresponde à aplicação de uma política pública que visou a expansão da Rede Federal de Educação Profissional e Tecnológica.

A Lei no 11892 de 2008, ao criar ou transformar instituições centenárias em novos complexos educacionais, também estabeleceu uma nova configuração ás estas mesmas instituições, por meio dos objetivos e características definidas pela legislação. Foram considerados a verticalização do ensino, a autonomia, as relações 
com os arranjos produtivos locais, os quais se destacam como características, objetivos e finalidades mais impactantes para a gestão do ensino. A legislação instituiu ainda um novo modelo de gestão similar ao das universidades federais, com Reitoria, Pró-Reitorias de Ensino, Pesquisa, Extensão, Administração, com controle das finanças a nível de reitoria, já que a nível de campus a direção apresenta um organograma próprio.

O modelo de gestão é algo superior à estrutura organizacional e compreende a relação existente entre todos os funcionários com suas atividades definidas em documentos institucionais. Em se tratando do IFPI, o modelo de gestão do ensino está dividido na Pró-Reitoria de ensino, descrita nos artigos 74 a 96 da Subseção III, do Regimento Interno e na Diretoria de Ensino de cada um dos seus vinte campi ente, trazida nos artigos de 230 a 255 da Seção II do documento supracitado.

Os IFs, por serem instituições novas, ainda estão em processo de adaptação e podem encontrar na gestão mecanismos que venham a contribuir para o seu fortalecimento e consolidação. São instituições que já nasceram em meio a dúvidas e questionamentos, principalmente quanto à sua identidade. $\mathrm{E}$ ainda apresentam uma estrutura de gestão que, em um primeiro nível, se parece com das universidades, mas que a nível de campus se torna bem diferenciada. Dentre as características da gestão, buscou-se focalizar no ensino, por ser a dimensão mais forte em uma organização escolar e por ser o centro de todas as atividades pedagógicas.

É relevante pesquisar o modelo de gestão aplicado ao ensino, pois se abre a possibilidade de encontrar mecanismos que tornem o processo de ensinar mais eficiente e eficaz, valorizando os aspectos próprios da comunidade local.

A motivação em realizar a pesquisa é o fato de já ter vivido a experiência de gestora de ensino e pela necessidade de compreender porque os IFs têm um gestor a nível de campus para tratar especificamente do ensino.

O tipo de pesquisa adotado foi a qualitativa, largamente utilizada nos estudos no campo da educação.

A pesquisa de campo ocorreu no Instituto Federal de Educação, Ciência e Tecnologia do Piauí (IFPI), tanto no Campus Corrente, quanto nas dependências da Reitoria, localizada na cidade de Teresina - PI. 
Os instrumentos de coleta de dados foram: análise documental, observação não participante, grupo focal, entrevistas semiestruturadas e questionários abertos. Os dados brutos foram organizados em grupos de análises, sendo que aquilo que se obteve por meio da análise documental e observação não participante formou um grupo e, noutro, agruparam-se os dados provenientes do grupo focal, das entrevistas e dos questionários. Para análise dos dados, mais especificamente para as entrevistas semiestruturadas, questionários abertos e 0 grupo focal adotou-se o processo de categorização, segundo Bardin (2011). Para a tabulação dos dados e análise, também foi utilizado o software WELF QDA.

Para apresentar a pesquisa, foram organizados quatro capítulos que compõem esta dissertação. No capítulo primeiro, tem-se o referencial teórico que aborda os mecanismos de gestão, buscou-se comentar o contexto histórico da administração pública no Brasil à luz das considerações de Junquilho (2012) e Bresser Pereira (2006) e suas repercussão na gestão educacional. Há uma abordagem sobre o conceito de políticas públicas e seu ciclo desde sua implementação até sua avaliação. O termo modelo foi explorado para delimitar o seu conceito e assim definir o modelo de organização das universidades federais e estabelecer a relação com o modelo de gestão dos IFs. Ainda buscou-se caracterizar os IFs a partir de seus objetivos e modelo de gestão e abordando também a gestão aplicada ao ensino.

O segundo capítulo trata da metodologia, fazendo um resgate sobre a importância da pesquisa. Também retrata discussões atuais sobre gestão de ensino, no tocante à nomenclatura, estrutura organizacional e características. Ainda foram exploradas as vantagens e desvantagens da pesquisa qualitativa, explicação dos métodos de pesquisa, do lócus de investigação, detalhando a amostra e ainda a forma de tabulação e tratamento dos dados.

O capítulo terceiro traz os resultados e discussões a respeito dos dados coletados, onde foi evidenciado que o modelo de gestão aplicado ao ensino no IFPI, apresenta fragilidades quanto a algumas características dos IFs, no sentido da verticalização, das várias modalidades de ensino ofertadas, da falta de sintonia do planejamento com os arranjos produtivos locais, a dificuldade da Pró-Reitoria de Ensino em monitorar e acompanhar as ações de ensino nos campi e dificuldade de comunicação entre Pró-Reitoria e vice versa, além de outros pontos relevantes.

O quarto capítulo trata do produto técnico, uma sugestão de intervenção diante dos resultados obtidos. O produto técnico consiste na criação de um ambiente 
virtual, denominado de AVGE - Ambiente Virtual de Gestão do Ensino, que tem como objetivos: auxiliar a PROEN E DIREN no monitoramento das ações e projetos de ensino em tempo real, facilitar a comunicação e a interação com todos os membros da equipe gestora, tanto a nível de estado, como de Campus; armazenar dados sobre carga-horária e formação docente, capacitar os gestores de ensino nos fundamentos da gestão pública, possibilitar aos docentes acompanhar todas ações de ensino e alimentar as informações no dia a dia, promover interação entre docentes de campi diferentes, propiciar a participação de alunos, com espaço reservado para suas opiniões e críticas, sobre o planejamento de ensino executado pela POREN, oportunizar à equipe gestora reflexão sobre suas ações, planejando-as ou reforçando sua utilidade. Neste capítulo há o detalhamento do ambiente virtual, com as especificações técnicas, com ilustrações que permitem visualizar algumas partes do ambiente virtual.

Para finalizar, o último capítulo apresenta as considerações finais, ressalta algumas questões que detalham os resultados da pesquisa, além de acrescentá-los.

Por fim, eis um convite para conhecer o modelo de gestão aplicado ao ensino no IFPI, frente às configurações dos IFs. 


\section{REFERENCIAL TEÓRICO}

\subsection{ASPECTOS CONTEXTUAIS}

\subsubsection{Percurso histórico da Gestão Pública}

A Administração Pública passou a ser denominada de Nova Gestão Pública, e essa concepção começou a ser empregada no Brasil a partir de 1970, compreendendo um conjunto de pressupostos que introduziram na gestão governamental ideias já praticadas no setor privado da economia mundial. Cabe fazer algumas observações sobre a natureza da administração pública, e ainda, uma retrospectiva para compreender o modelo atual de gestão.

Junquilho (2001), agrupa as considerações sobre administração ou gestão em três blocos. O primeiro diz respeito a um conjunto de técnicas de como administrar, uma ferramenta neutra e objetiva, baseada em modelos prontos para serem aplicados, um receituário pré-formatado, de "cima pra baixo" em busca de resultados coletivos pré-estabelecidos e pronto para ser utilizado em qualquer órgão ou organização do governo. No segundo bloco, a administração dá ênfase à política das organizações, o gerenciamento dos conflitos internos entre grupos, no que tange à influência nas decisões e disputas de poder dentro das organizações. No último bloco, a administração é pensada numa perspectiva crítica, sob forte influência de Karl Marx, atribuindo a ela um mecanismo de controle social para satisfazer interesses do capitalismo. Logo, a tríade técnica, conflitos entre grupos e pessoas, ainda é observada na gestão pública, devido as influências dos tipos que caracterizaram à administração ao longo da história (JUNQUILHO, 2012). Considerando a tipologia da Administração Pública, destaca-se a Administração Pública Patrimonialista, Burocrática, Nova Gestão Pública - Gerencial.

A Administração Pública Patrimonialista caracteriza-se pela predominância do Estado com poder de monarquia, gera o nepotismo (favorecimento de parentes), empreguismo e os servidores públicos possuíam status de nobres. 
Junquilho (2012), caracteriza a Administração Pública Patrimonialista como sendo aquela em que todos os cargos da estrutura administrativa do Estado, estão sob o domínio pessoal do soberano. Os funcionários patrimonialistas podiam ascender nos cargos desde que houvesse determinação do mandatário, ou se comprassem ou ainda, por arrendamento. O governo - monarca - é fortemente centralizador, não havia separação entre o patrimônio pessoal do monarca e o público, a economia baseada em relações comerciais. As forças armadas eram fiéis ao soberano e também havia muita corrupção. A configuração patrimonial perdurou até meados do século XVIII, com o fim da monarquia absolutista.

Uma outra tipologia de Administração Pública é a Burocrática. Esta foi adotada para substituir a Administração Patrimonialista. Com o capitalismo industrial e as democracias parlamentares, que surgiram no início do século XIX, as novas relações comerciais impunham a necessidade de separação entre o estatal e o privado. Outras características da administração pública burocrática, segundo Junquilho (2012), consistem na definição de uma hierarquia administrativa (organograma), com a distribuição de funções e autoridade de órgãos e de cargos. As ações são estipuladas aos servidores públicos por decretos, leis e portarias. ingresso para os cargos de carreira na Administração Pública é realizado via concurso público, por meios meritocráticos.

Segundo Bresser (2006), no Brasil, a Administração Pública Burocrática entra em crise no Regime Militar devido à incapacidade de extirpar o patrimonialismo, o que não consolidou a burocracia, pois ao invés de se promoverem concursos públicos para alta administração, preferiu-se contratar administradores de empresas estatais.

\footnotetext{
A crise agravou-se, entretanto, a partir da Constituição de 1988, quando se salta para o extremo oposto e a administração pública brasileira passa a sofrer do mal oposto: o enrijecimento burocrático extremo. As consequências da sobrevivência do patrimonialismo e do enrijecimento burocrático (BRESSER, 2006 p.3).
}

A Administração Burocrática, na concepção de Bresser (2006), é lenta, cara, auto referida, pouco ou nada orientada para o atendimento das demandas dos cidadãos.

No contexto mundial, os esforços eram para a superação da crise do sistema capitalista, 
[...] que se configurava, a partir da década de 1970 e se aprofundava na década de 1980, surgiram medidas para melhoria da qualidade da administração, bem como do sistema judicial e político. Essas reformas visavam a modificar a legislação, a administração pública e a estrutura do governo central para dar maior governabilidade ao Estado (ARAÚJO E CASTRO, 2011, p.87).

Nos anos de "1980 inicia-se uma grande revolução na administração pública dos países centrais em direção a uma administração pública gerencial", (BRESSER, 2006, p.5). A nova gestão pública, baseava-se nos critérios de eficiência, de eficácia e de produtividade, seguindo a referência do modelo empresarial, descentralizado, com ênfase no cliente (ARAÚJO e CASTRO, 2011).

O termo Nova Gestão Pública, na literatura nacional, traduz a expressão inglesa New Public Management. Ambas significam, na literatura internacional, as reformas do Estado a partir dos anos 1970, baseadas na corrente gerencialista do pensamento administrativo (JUNQUILHO, 2012, p. 54).

Junquilho (2012) elenca alguns pontos que caracterizam a denominada Nova Gestão Pública: gasto público improdutivo, servidores públicos detentores de privilégios, distribuição de bens e serviços à sociedade, o Estado com o papel principal de promotor/empreendedor, controle de resultados, governança, governabilidade, prevenção e controle de gastos; mudança de papel dos chamados administradores públicos para gerentes ou gestores públicos profissionalizados, típico do modelo burocrático de gestão, incentivo à gestão por contratos, a marginalização das representações sindicais e a privatização de setores econômicos produtivos estatais, influência do Neoliberalismo, onde o novo modelo de gestão pública é apoiado.

Por fim, a Nova Gestão Pública ou Gerencial, como denominou Bresser (2006), está em vigor em todas as instituições estatais. O governo tem buscado, através de novo modo de gerenciamento da coisa pública, implantar novas ações, em busca da qualidade dos serviços e assim as mudanças ocorridas tem impactado várias áreas, inclusive as áreas sociais, como o campo da educação. Cabe saber: quais as repercussões deste novo modelo na gestão educacional?

\subsubsection{Repercussões das mudanças de gestão pública na gestão educacional}


As mudanças ocorridas na Gestão Pública tiveram influência direta da necessidade de reorganização do capital, ocorridas no século $X X$, que buscava superar o modelo de produção tayloristalfordista ${ }^{1}$, em crise e que fora considerado lento, rígido e padronizado e não atendia mais ao mercado. Era necessário um modelo mais ágil, flexível para responder rapidamente à crescente necessidade de consumo da sociedade. A nova forma de gerenciamento do setor tem no modelo empresarial a sua referência, cujos princípios de eficiência, eficácia e de produtividade estão ligados a um planejamento estratégico, com metas e objetivos bem estabelecidos, nesse contexto a "dimensão da gestão educacional passou a ser evidenciada como uma estratégia de sustentação da reforma, fundamental para o sucesso da aprendizagem e a melhoria da qualidade da educação" (ARAÚJO E CASTRO, 2011, p.83).

Para adequar a educação ao novo contexto de gerenciamento e ao o novo modo de produção flexível, com a liberação e abertura dos mercados era necessário modernizar a gestão educativa e superar a gestão burocrática da educação. Então, o caminho encontrado foi a adoção de estratégias que possibilitassem a descentralização do sistema público de ensino. No Brasil, a Lei Federal n. 9.394 de 20 de dezembro de 1996, que instituiu as Diretrizes e Bases da Educação Nacional LDB/1996 - trouxe a redistribuição de responsabilidade da educação pública, entre os entes federados (União, Estados e Municípios). Outra medida foi o estímulo à participação e ao controle da sociedade, por meio de modelos de gestão que privilegiassem os órgãos colegiados e conselhos, instalados em todas as esferas educacionais e no interior de cada escola pública.

$\mathrm{Na}$ gestão educacional nacional, não havia mais espaço para a "forma burocrático-piramidal de administração". Nesse caso, houve estímulos legais para diminuição dos níveis hierárquicos e a valorização da autonomia de decisão por parte dos gestores (CASTRO, 2006).

$\mathrm{Na}$ educação brasileira, em busca da qualidade, eficiência e eficácia, vocábulos que inclusive se tornaram o centro do debate nas escolas públicas, os gestores administrativos desenvolveram medidas para que a gestão escolar de fato

\footnotetext{
${ }^{1} \mathrm{O}$ taylorismo e o fordismo. Sistemas que visavam à racionalização extrema da produção e, consequentemente, à maximização da produção e do lucro. FRANCISCO, Wagner De Cerqueria E. "Taylorismo e Fordismo"; Brasil Escola. Disponível em http://www.brasilescola.com/geografia/taylorismo-fordismo.htm>. Acesso em 10 de setembro de 2015.
} 
adotasse o modelo gerencial. Medidas como estabelecimento de um núcleo gestor em cada unidade escolar, processo de eleição para escolha dos dirigentes, investimento em formação de gestores, estratégias de planejamento, tanto no nível geral da educação nacional como específico, em cada unidade escolar, são exemplos desse fato. Também o Plano de Desenvolvimento da Educação (PDE), ou o Plano de Desenvolvimento Institucional (PDI) e vários outros, tais como o Plano Nacional de Educação (PNE), o Plano Estadual de Educação (PEE) ou ainda o Plano Municipal de Educação (PME) estabelecem metas, estratégias, resultados para as organizações educacionais.

Muitas dessas medidas são reflexo de intervenções de organismos internacionais, dentre os quais se destacam o Banco Mundial, Banco Interamericano de Desenvolvimento (BID), Fundo Monetário Internacional (FMI), Organização Mundial do Comércio (OMC) e a Organização das Nações Unidas para a Educação, a Ciência e a Cultura (UNESCO), passaram a financiar programas e projetos em busca da uniformização dos índices educacionais, exigindo investimentos, criando critérios de qualidade, que tem como parâmetro a qualidade do mercado, tudo para atender ao modelo gerencial de gestão. No entanto, mesmo com todos os investimentos, ainda existem entraves no processo de mudança de gestão na educação nacional.

Fica evidenciado, dessa forma, que o modelo de gestão gerencial, orientado pelas agências internacionais, não tem conseguido superar o modelo de gestão burocrática que predominava nas escolas, como prognosticaram os apologistas do livre mercado. O que se constata é a transformação desta em uma burocracia flexível, e principalmente, coerente com o novo modelo de produção (ARAÚJO E CASTRO, 2011, p.107).

O modelo de gerencialismo influenciou diretamente o modelo de gestão, também em outros aspectos tais como descentralização de serviços, modelos de avaliação de desempenho, exigência de maior transparência e responsabilidade por parte dos gestores, modelos de controle de qualidade, possibilidade de parceria público-privado, dentre outras medidas que se possa elencar.

Existem críticas a esse novo modelo de gestão e uma das mais contundentes pauta-se na "apropriação inadequada dos termos participação, autonomia, descentralização dos recursos, pois são usadas na lógica gerencial, como 
um meio de racionalizar recursos e não como mecanismo de gestão democrática" (ARAÚJO E CASTRO, 2011, p.104).

O fortalecimento da participação efetiva da comunidade no processo educacional, em específico no âmbito da gestão educacional, demanda que as ações governamentais procurem estar mais em consonância com as necessidades da população escolar e assim, favorecer o caminho para implementações de políticas públicas articuladas com as comunidades locais. Como a implantação das políticas públicas tem relação direta com a gestão pública, é pertinente ter noção do conceito e do desenvolvimento do ciclo da política pública, desde a sua elaboração até o processo de avaliação.

Então, para que o novo modelo de gestão seja realmente útil a quem faz uso direto da escola, é necessário que se privilegie o interesse local, que se planeje dentro das especificidades regionais, sendo o caminho, o diálogo, de modo que se estabeleçam discussões que culminem em políticas públicas de interesse da sociedade. Mas, o que são políticas públicas?

\subsubsection{Políticas Públicas: Ações Governamentais}

Desde a promulgação da Constituição Federal de 1988 e com o advento da LDB/1996, nota-se que a educação tem sido objeto de maior preocupação na administração do Estado. Alguns avanços se fazem visíveis, com destaque para universalização do acesso ao Ensino Fundamental e a ênfase na redução de taxas como evasão e repetência. Além disso, todas as esferas de governo, aqui concebidas como os diferentes tipos de entes federados (a União, os Estados, os Municípios e o Distrito Federal) aumentaram os seus investimentos no setor educacional. Conforme mostram dados do Instituto Nacional de Estudos e Pesquisas Educacionais Anísio Teixeira - INEP, em 2000, o investimento em educação no País era na ordem de 4,6\% do PIB, passando para 6,2\% em 2013. Isso se deve à tentativa de melhorar a infraestrutura das escolas, as condições de estudo para a permanência com êxito dos alunos, valorização docente e ampliação da oferta de vagas em todo os entes 
federados. Dentre outros avanços, deu-se início ao processo de valorização dos professores, sendo tais conquistas oriundas de políticas públicas na área educacional.

Os estudos sobre política pública no Brasil são ainda recentes, o que dificulta obtermos uma definição clara para o termo. Percebe-se que há ainda algumas divergências conceituais, as quais ora têm um olhar mais amplo sobre o conceito de política pública que não se concentra só em quem elabora a política, mas na origem do problema e nos atores envolvidos, ora centralizam o conceito de política pública como uma ação exclusiva do Estado, onde este é responsável pela elaboração, execução e monitoramento das ações da política pública. Para Hofling (2001, p.31), política pública "é o Estado implantando um projeto de governo, através de programas, de ações voltadas para o setor específico da sociedade". Tal concepção se relaciona ao conceito da primeira vertente. À margem dos conflitos conceituais e considerando o âmbito teórico, política pública é instrumento de intervenção, um mecanismo de atuação do Estado frente às demandas sociais, de forma sistematizada. É um campo multidisciplinar com o foco nas explicações, um problema ou carência e nas "interrelações entre Estado, política, economia e sociedade", para elaborar mecanismos de intervenção na realidade, ações que provoquem mudanças (SOUZA, 2006).

As políticas públicas tiveram e têm um papel determinante no tocante à celeridade de implementação de medidas, como programas para a alocação de recursos financeiros, que venham a atender às demandas, no campo da saúde, da segurança pública, da educação, enfim, das necessidades da sociedade.

As políticas públicas compreendem um ciclo de existência, iniciando com um diagnóstico da realidade, depois formulação da política, tem-se a implementação, monitoramento e por fim, o ciclo se fecha com à avaliação da política. Para melhor compreensão desse ciclo, é necessário um entendimento, mesmo que superficial, de como surge uma política e em que momento ela se configura como ações e projetos.

Dentre alguns modelos explicativos de formulação de políticas públicas, considera-se a tipologia que defende as políticas como deliberativas e as têm como um processo dinâmico e como tal, seguem alguns estágios básicos, que podem ser precedidos de pressões sociais, mobilizações, jogos de interesses que compõem a pauta de discussão, desencadeando em etapas que irão compor o ciclo de "vida" de uma política. "O ciclo da política pública é constituído dos seguintes estágios: definição da agenda, identificação de alternativas, avaliação das opções, seleção das opções, 
implementação e avaliação" (SOUZA, 2006, p.10). Januzzi (2005) assim concebe o ciclo de uma política pública:

Em sua forma clássica o círculo de formulação e avaliação de políticas públicas é composto pelas etapas de Diagnóstico, Formulação, Implementação e Avaliação. Capa etapa desse ciclo envolve um conjunto de indicadores de diferentes naturezas e propriedades em função das necessidades intrínsecas das atividades nelas envolvidas (JANUZZI, 2005, p.03).

$\mathrm{Na}$ etapa Diagnóstico, é momento de colher informações que traduzam com clareza e maior precisão possível a realidade. Para obter uma visão fidedigna desta, é necessário, antes de mais nada, muito critério para lançar mão de dados, de fontes confiáveis e indicadores que, de fato, traduzam todas as facetas da situação. Januzzi (2005) defende que o diagnóstico é o "Marco Zero" a partir do qual já é possível avaliar se o programa está tendo o resultado esperado, por isso alerta que a sondagem necessita ser ampla, detalhada e prioritária. Como indicadores mais recomendados, preconiza-se para esse momento os censos demográficos ou pesquisas amostrais multitemáticas (JANUZZI, 2005).

A Formulação é a segunda etapa do ciclo de elaboração das políticas públicas. Preliminar a essa etapa, é necessário a definição da agenda político social, que consiste em identificar e delimitar um problema atual ou potencial da sociedade e assim determinar as possíveis alternativas para sua solução. Também devem ser analisados os custos e seus efeitos, bem como estabelecer as prioridades. Na etapa de Formulação acontece a seleção e especificação da alternativa considerada mais conveniente, seguida de declaração que explicita a decisão adotada, definindo seus objetivos e seu marco jurídico, administrativo e financeiro. Os indicadores mais adequados nessa etapa são os indicadores sintéticos e multicriteriais, porque "oferecem ao gestor uma medida-síntese das condições de vida, vulnerabilidade, desenvolvimento social de municípios, estados ou outra unidade territorial de implementação de programas" (JANUZZI, 2005).

$\mathrm{Na}$ etapa de Implementação, já se tem definida a agenda, as alternativas avaliadas e selecionadas, segue então, para o momento de implementar a política pública. Segundo alguns autores, há duas perspectivas nessa fase, uma de análise top-down e outra de abordagem botton-up. Porém, 
(...) o fracasso na implementação de políticas públicas pode ser atribuído a duas abordagens antagônicas: top-down - perspectiva em que a decisão política é autoritária, em um nível central e a botton-up - abordagem que leva em consideração a complexidade do processo de implementação. Resgatam das contribuições de outros estudiosos, o autor levanta características do processo: um mapeamento para trás e não para frente; foco na estrutura de execução e no processo de negociação; nas ações entre e dentre redes de implementadores; capacidade de acomodar acontecimentos imprevistos e imprevisíveis, além da capacidade de ser adaptável (NAJAN, 1995, p.03).

Os atores e organizações têm suas demandas e peculiaridades, que necessitam ser alinhadas para que a implementação de uma política pública, seja justificável pela necessidade real, mas a questão crucial é o diálogo entres os atores, já que "é preciso ter uma visão estratégica dos problemas de implementação, incorporando questões críticas como a viabilidade e problemas de coordenação interorganizacional no momento do planejamento" (NAJAN, 1995). Nessa etapa, os indicadores de modo geral devem buscar a especificidade, ser atuais e ter regularidade. Considerando que o planejamento de política pública é multifacetado, implementá-la de uma forma que agrade a todos, torna o processo ainda mais complexo.

A Avaliação é a última etapa do ciclo de formulação das políticas públicas, à luz de algumas fontes bibliográficas. Considera-se que a avaliação de políticas públicas tem por finalidades estabelecer elementos para julgar e aprovar decisões, ações e seus resultados, desenvolver e melhorar estratégias de intervenção da realidade, ou seja, a avaliação tem que ser capaz de propor algo a respeito da política que está sendo avaliada e deve abrir espaço à democratização da atividade pública, considerando grupos sociais excluídos, promover o aprendizado institucional e fortalecimento das instituições envolvidas.

Para Rua (2010), a avaliação pode variar, também, conforme a lógica que orienta sua concepção. Nesse caso, pode-se falar de avaliação ex-ante e de avaliação ex-post. Numa definição mais generalizada, a avaliação ex-ante expressa uma concepção holística, interativa, segundo a qual a avaliação se inicia desde o momento em que se define o problema ou necessidade, que justifica a política, integra as discussões em torno da formulação das alternativas, envolve a tomada de decisão, e acompanha o processo de gestão, informando-o sobre os seus avanços, riscos e limitações, desvios a corrigir e vantagens. Numa outra definição restrita, a avaliação ex-ante consiste na análise de eficiência e na análise de impacto. A avaliação é um processo dinâmico e complexo, que para cumprir o seu papel de revelar a "verdade" 
é necessário adotar alguns critérios. Além da eficiência e eficácia, há de considerar efetividade, equidade e sustentabilidade. Esses critérios para serem avaliados, necessitam de indicadores ${ }^{2}$. Na concepção de Januzzi (2005),

\begin{abstract}
A avaliação de um programa público requer indicadores que possam dimensionar o grau de cumprimento dos objetivos dos mesmos (eficácia), o nível de utilização de recursos frente aos custos em disponibilizá-los (eficiência) e a efetividade social ou impacto do programa. Os indicadores de desembolso de recursos e produtos construídos a partir de registros próprios de controle e gerenciamento ade programas - podem permitir uma avaliação indireta da eficácia dos programas no alcance das metas estabelecidas, quando as estatísticas públicas ou os dados administrativos de Ministérios e Secretarias Estaduais não disponibilizarem dados específicos, periódicos e na escala territorial desejada (...). Na avaliação da eficiência, é importante analisar os indicadores de resultados a partir dos indicadores de esforços e recursos alocados, o que permite o dimensionamento da eficiência dos programas (JANUZZI, 2005, p.11).
\end{abstract}

Para avaliar é necessário lançar mão de um conjunto de métodos de diagnóstico e análise. É preciso que a avaliação seja capaz de captar mudanças através do tempo, retroalimentando as políticas. Desse modo, é pertinente submeter uma política pública à análise, pois é provável que possibilite a identificação de pontos falhos e ou sensíveis, também a própria avaliação pode indicar soluções.

\title{
1.1.3 Considerações sobre o modelo de Gestão das Universidades Federais Brasileiras
}

A discussão atual que perpassa o campo da gestão das instituições públicas de ensino superior (IES) relaciona-se com a complexidade de uma estrutura organizacional que possa atender a uma diversidade de objetivos institucionais, contemple mudanças na sociedade, no mercado de trabalho e que ainda incorpore, desenvolva e ponha em ação inúmeras políticas públicas.

O modelo atual de gestão das universidades públicas, apesar de algumas mudanças, porém pouco significativas, ainda está sedimentada nos princípios e

\footnotetext{
${ }^{2}$ Indicadores são variáveis definidas para medir um conceito abstrato, relacionado a um significado social, econômico ou ambiental, com a intenção de orientar decisões sobre determinado fenômeno de interesse. Indicadores para Análise de Políticas Públicas A SEI e os indicadores para subsídio ao Planejamento da Bahia. www.sei.ba.gov.br. Acesso em 20 de outubro de 2015.
} 
características da reforma universitária ocorrida em 1968, por incremento da Lei no 5.540 de 1968, que estabeleceu novo modelo de gestão, segundo alguns autores, com forte evidência de importação de modelos estrangeiros (Bernardes e Lopes, 2005). Conforme Bernardes e Lopes (2005), para culminar na reforma universitária foram contratados consultores estrangeiros que junto com uma equipe brasileira definiriam os rumos do ensino superior no país. O consultor Rudolph Atcon apresentou como proposta uma nova estrutura administrativa universitária, cujo modelo seria baseado no modelo empresarial, uma vez que se pressupõe que a universidade representava o vetor de crescimento econômico. A proposta de Atcon não foi acolhida em sua essência, porque desvinculava o poder público das universidades, mas alguns critérios, como: unidade administrativa, unidade no ensino e pesquisa, organizado com racionalidade em departamentos fizeram parte da Lei 5.540/68 e que também inovou as IES, trazendo, formas inovadoras de organização hierárquica, dividida em três níveis das decisões administrativas, sendo: 1ํㅡível - Reitor, vice-reitores e Conselho Curador, Universitário e de Ensino e Pesquisa; 2ํㅡível setorial, pelos diretores de centros e conselhos de centros; 3ํㅡ nível local, pelos diretores de faculdades, de departamentos e respectivos conselhos (Vieira e Viera, 2004). E ainda,

(...) proporcionou quatro modelos básicos de estruturação para as universidades, no que se refere às atividades-fim: 1) agregação de departamentos em poucos centros; 2) reunião de departamentos em número maior de institutos; 3) ligação direta de departamentos à administração superior; e 4) superposição de centros aos institutos (BERNARDES E LOPES, 2005, p.08).

Com a gestão estruturada em departamentos, houve aumento no grau de burocratização e crescimento de procedimentos normativos (Vieira e Vieira, 2003), tanto no campo administrativo como no campo acadêmico, engessando as ações e tornando as instituições de ensino superior públicas organizações extremamente rígidas e intolerantes às mudanças, representando um grande paradoxo, pois são instituições que promovem conhecimento para gerar mudanças sociais, inovação e ao mesmo tempo são tão fechadas em si mesmas. "Entre as instituições públicas brasileiras as mais recalcitrantes, as mais impermeáveis e as mais retardatárias às mudanças são de longe as universidades federais" (VIEIRA E VIEIRA, 2004, p.182).

Em busca da definição do modelo de gestão universitário que tivesse atrelado às novas peculiaridades da sociedade, um marco importante foi a 
Constituição Federal de 1988, que trouxe no seu art. 206, parágrafo VI, o princípio de gestão democrática. Para longe do modelo burocrático, a gestão democrática baseiase no planejamento das atividades-meio (gestão administrativa, planejamento, políticas internas para solucionar problemas) das atividades-fim (ensino, pesquisa e extensão), no atendimento das prioridades e emergências das instituições, buscando a participação dos atores de variados segmentos nos processos decisórios,

(...) porém, em muitos casos, pratica-se mais a desconcentração marcada pela delegação regulada de responsabilidades, tutelada ainda pelo poder central, mediante o estabelecimento de diretrizes e normas centrais, controle na prestação de contas e a subordinação administrativa das unidades aos poderes centrais; do que a descentralização propriamente dita, caracterizada pela delegação de poderes de auto-gestão e autodeterminação na gestão dos processos necessários para a realização das políticas educacionais (ELPO, 2004, p.2).

Os pesquisadores da teoria das organizações já constataram a existência de um forte vínculo entre a estrutura administrativa e o processo decisório, ou seja, a decisão estratégica é influenciada pela estrutura. Leitão (1982), baseado no trabalho de Fredrikson ${ }^{3}$, admite que onde não há uma estratégia global institucionalizada há predomínio da estrutura organizacional nos processos decisórios, sendo assim, nessa perspectiva, o princípio democrático não se pratica de fato, pois não se adequa à velha estrutura organizacional das universidades.

Com a publicação da LDB Lei no 9394 de 1996, alguns artigos da Lei 5.540/1968 foram revogados e as universidades passaram a ter mais autonomia na organização dos seus cursos e programas, mas desde 1988, a Constituição Federal já estabelecia no Art. 207, que as universidades passariam a gozar de autonomia didático-científica, administrativa e de gestão financeira e patrimonial e teria que obedecer ao princípio de indissociabilidade entre ensino, pesquisa e extensão.

Leitão (1985) já admitia que a universidade pública, do ponto de vista organizacional, era a instituição mais complexa da sociedade moderna, devido às múltiplas tarefas que era obrigada a desempenhar e com a imposição constitucional de indissociabilidade do ensino-pesquisa-extensão, torna-a ainda mais complexa, uma vez que, embora interdependentes, o ensino, pesquisa e a extensão, tem

\footnotetext{
${ }^{3}$ Fredrickson, James W. The strategic decision process and organizational structure. Academy o[ ManagementReview,Georgia State University,II(2):280-97, 1986.
} 
características que os diferenciam e também foram sendo incorporadas às universidades em épocas diferentes, onde a cada nova incorporação exigia readaptação e uma readequação do modelo de gestão das instituições. O ensino foi a primeira missão da universidade, sendo substancialmente estabelecida no século XVI. No século XIX, a universidade é forçada a se adaptar à pesquisa como sua nova missão. E por fim, a absorção de uma terceira missão que se constitui na prestação de serviços à comunidade dada pela extensão (LEITÃO, 1985).

Estas três dimensões da atividade acadêmica universitária têm se tornado reféns de um processo administrativo rígido e burocrático incontrolável, submetido a normas e dependências muitas vezes desnecessárias produzidas pelas estruturas hierárquicas de poder. Nos setores mais dinâmicos da sociedade, as estruturas burocráticas que seguem o formato de pirâmide estão sendo substituídas por outras mais flexíveis, mais abertas e mais horizontais em sua hierarquia e na movimentação dos fluxos de demandas e decisões.

As universidades federais de todos os portes, em diferentes escalas, tornaram-se instituições altamente complexas, de ampla multiplicidade orgânica e de poderes segmentados. Para Garcia (2005), é comum haver uma separação entre a "parte acadêmica", que compreende a unidade de apoio às atividades acadêmicas e a "parte administrativa", que corresponde aos setores financeiro, infraestrutura e recursos humanos. Na avaliação do autor, é um erro considerar essa divisão, porque não tem fundamentação estratégica e corrobora para a supervalorização de uma "parte" em detrimento da outra.

Nestes termos, "é evidente, pela sua própria organização, que a Universidade é reflexo do Estado e da Sociedade em que se situa, o que, por sua vez, leva ao paradoxo de caber a ela expressar aquilo que dela se espera" (ROSENTHAL, 1982, p. 23). A rigidez do caráter unitário do modelo de universidade adotado no Brasil tem sido alvo constante de críticas, argumentando-se que hoje, apesar do aspecto legal, ainda existe uma clara ruptura entre o ensino, pesquisa e extensão. Parece que, na realidade, há uma completa dissociação entre a finalidade que as universidades foram criadas e sua atuação na sociedade atual.

Segundo Leitão (1989), o elevado grau de intervenção do Estado nas universidades de modo geral e nas universidades públicas especialmente, através da consolidação de sua tecnoestrutura, traz como consequências imediatas: a hipertrofia das atividades-meio em relação às atividades-fim; o conflito entre autoridades 
burocráticas e autoridades profissionais; e a inadequação das decisões face ao conteúdo do problema, posto que acabam sendo baseadas unicamente em regulamentações genéricas.

Bernardes e Lopes (2005), destacam três grandes desafios da gestão universitária. Em um primeiro aspecto, há de se considerar a manutenção do pluralismo político das comunidades discente, docente e administrativa. Em segundo lugar, tem-se o desafio em que se constitui a execução das atividades para o alcance de objetivos no ensino, pesquisa e extensão. Por fim, o desenvolvimento institucional através das políticas públicas constitui-se em outro desafio. Mas, segundo os autores, o maior problema na estruturação administrativa das IES é a busca de um modelo que atenda as especificidades e ao mesmo tempo o pluralismo político e ideológico para o entendimento de um projeto de universidade.

Apesar das divergências na comunidade acadêmica, Bernardes e Lopes (2005), ressaltam que há consenso e concordância em dois aspectos: a missão universitária de produzir e disseminar conhecimento e a necessidade de organização e planejamento das atividades. Mas, o que se percebe pela análise da literatura é que as universidades públicas muitas vezes se organizam, planejam suas atividades em função de responder favoravelmente às questões referentes a avalição externa a que estão submetidas e acabam transferindo responsabilidades decisórias internas a outros órgãos públicos, particularmente o Ministério da Educação.

Percebe-se ainda, no cenário de gestão, uma forte disputa por cargos e ocupações e que muitos reitores utilizam sua autoridade para se valer de indicações, como moeda de troca para perpetuação no poder, uma vez que a legislação permite a reeleição dos gestores, característica do modelo burocrático de gestão.

Enfim, fica evidente que o modelo de gestão das IES públicas, já não corresponde à sua realidade e que não só a legislação precisa sinalizar mudanças na estrutura organizacional, mas que as instituições estejam abertas, para assumir novos arranjos administrativos e também buscar condições para consolidar a gestão democrática e participativa. 


\subsection{Conceito: Modelo}

A palavra modelo vem do Latim modulus e significa "medida", "padrão4", também expressa molde, forma. Para Campos (2009, p.129), é "uma descrição projetada para mostrar o objeto principal ou o funcionamento de um objeto, um sistema ou um conceito". Modelos são usados no nosso dia a dia, nas instituições públicas e privadas, no desenvolvimento de projetos de várias áreas do conhecimento, pela praticidade, por facilitar a descrição visual de uma situação.

\footnotetext{
Fluxogramas, tabelas, figuras, gráficos, equações, esquemas, mapas conceituais (...) são exemplos de modelos, usados como recursos cognitivos de uso generalizado na representação e descrição de uma dada situação ou contexto, na busca do entendimento dos conceitos utilizados na geração e difusão do conhecimento. São milhares os tipos de modelos, geralmente instrumentos visuais utilizados em várias áreas e funções como análise, gestão, comunicação (ALMEIDA NETO, 2013, p.130.).
}

No contexto organizacional, o termo modelo vem sendo empregado na perspectiva de ser algo que deve ser seguido. Trata-se de uma forma de organização e sistematização das ações, que busca gerir os serviços ofertados com maior qualidade, procurando melhorar o desempenho institucional. Um modelo, por si só, não é suficiente, necessita ser gerido, administrado, gerenciado, papel que cabe à gestão.

Pode-se considerar a gestão como um arcabouço de práticas que modificam bens intelectuais de determinada organização em maior produtividade, novos valores e aumento de competitividade. A gestão tem se tornado um fator determinante para o sucesso das organizações, o que tem delas demandado mais planejamento, maior rigor nas definições de padrões para gerenciamento, evitando improvisos e lidando com modelos para direcionar suas ações na administração. Neste sentido, o desenho que norteia as decisões tomadas em um meio organizacional é conhecido como Modelo de Gestão. Por Modelo de Gestão, compreende-se também o trabalho de gerir determinada organização através de um

\footnotetext{
${ }^{4}$ MODELO. In: Dicionário Michaelis. Disponível em: <www. uol.com.br/michaelis>. Acesso em: 20 set. 2015.
} 
modelo, seguindo um exemplo já existente que pode ser readequado e readaptado, realizando-se apenas as modificações que se fizerem necessárias em cada local em que for implementado (FERREIRA, 2005). Mais especificamente, no campo da gestão, o modelo de forma simplista pode ser representado por organogramas, fluxogramas com a disposição dos cargos administrativos, exposição da organização hierárquica e a relação entre os cargos.

Os modelos permitem uma tentativa de visualização do conhecimento. Não só na ciência como também no mundo organizacional os modelos são uma representação da realidade que pode ser então explicada matematicamente e por meio de diagramas e gráficos (CAMPOS, 2009, p.53).

Figura 1 - Sobre Teoria dos Modelos

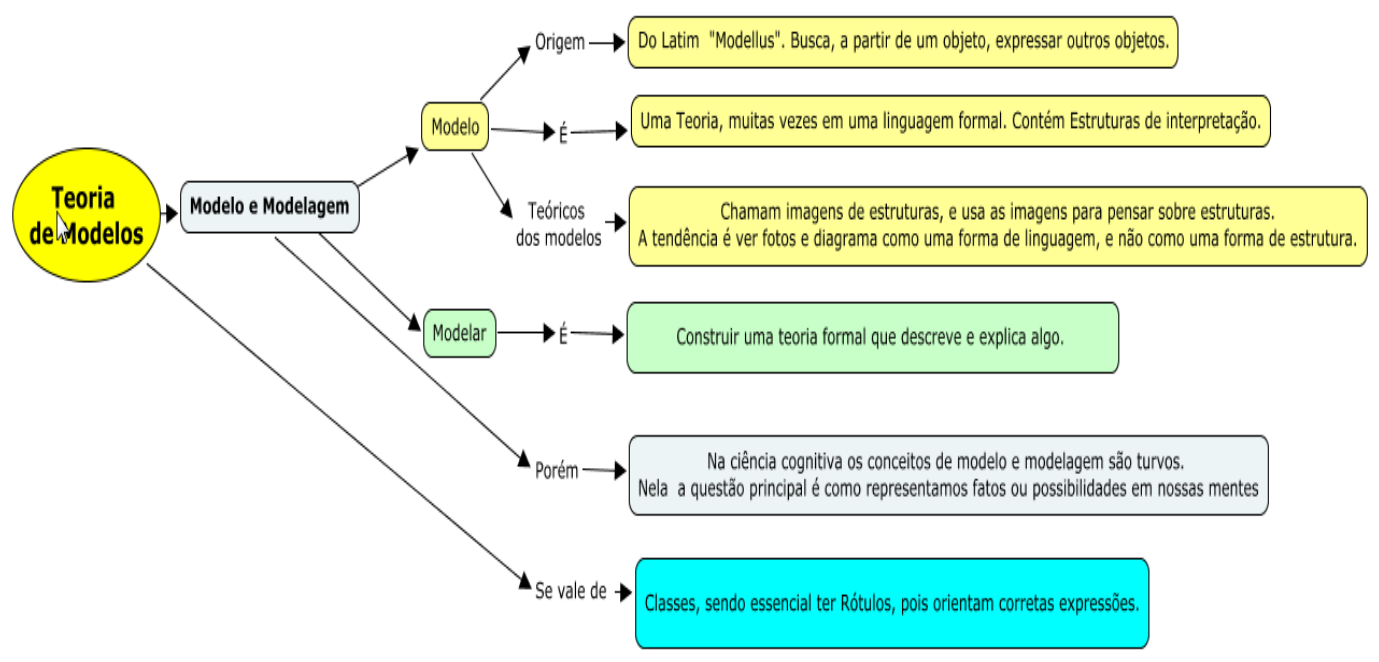

Fonte: Almeida Neto, 2013.

Modelo de gestão, mesmo sendo uma representação prática, implica dizer que estão ligados às concepções filosóficas, ideológicas e ou políticas da administração no local em que se aplicam. No contexto da administração pública, também se verificam novos modelos de gestão dependendo das influências da política econômica, do mercado capital, enfim, do tipo de governança estabelecido para a sociedade em uma determinada época. Assim, faz-se necessário percorrer a história da administração, em particular da administração pública, para contextualizar o modelo de gestão nas diferentes nuanças assumidas ao longo do tempo. 
2.1 EDUCAÇÃO PROFISSIONAL, CIENTÍFICA E TECNOLÓGICA NO BRASIL: UM RESUMO HISTÓRICO

Em 23 de setembro de 2015, a Rede Federal de Educação Profissional, Científica e Tecnológica completou 106 anos de existência no Brasil.

Do período colonial, em que o trabalho era desprezado pelas elites, ao século XXI, com a expansão da tecnologia e da ciência no cotidiano da população, a Educação Profissional e Tecnológica passou por história controversa, com ciclos de valorização e crescimento alternados a momentos de estagnação e retração.

Com base em Tavares (2012) e Brasil (2009), podemos dividir a história da Educação Profissional no Brasil em fases, conforme o Quadro 1.

\section{Quadro 1 - Fases da Educação Profissional no Brasil}

\begin{tabular}{|c|c|}
\hline Fase & Duração \\
\hline 1. Primórdios da Educação Profissional no Brasil & $1500-1889$ \\
\hline 2. Educação dos "Desvalidos" & $1890-1955$ \\
\hline $\begin{array}{l}\text { 3. Teoria do Capital Humano e a expansão da Rede Federal de } \\
\text { Educação Profissional }\end{array}$ & 1956-1984 \\
\hline 4. Estagnação da Rede Federal de Educação Profissional & 1986-2002 \\
\hline $\begin{array}{l}\text { 5. Retomada da expansão da Rede Federal de Educação } \\
\text { Profissional e Tecnológica }\end{array}$ & $2003-2010$ \\
\hline $\begin{array}{l}\text { 6. Consolidação da expansão da Rede Federal de Educação } \\
\text { Profissional, Científica e Tecnológica }\end{array}$ & $2005-2020$ \\
\hline
\end{tabular}

Fonte: Elaborado pela autora com base em Tavares (2012)

Por questões didáticas, optamos por dividir a primeira fase em dois períodos, tendo como marco a vinda da Família Real Portuguesa para o Brasil.

A primeira fase ocorre do período colonial ao Término do Segundo Reinado. Nesta fase, Tavares (2012) afirma que a oferta de Educação Profissional era 
desnecessária, sendo o trabalho executado por índios e africanos em regime de escravidão, em sua maioria, "(...) os quais não careciam de escola para ensinar seu ofício às gerações futuras. Aprendia-se a trabalhar no próprio trabalho" (TAVARES, 2012). Tavares (2012) acrescenta que a elite local nutria verdadeiro desprezo pelo trabalho, sobretudo as ocupações manuais, o que justifica seu desinteresse pela oferta de educação profissional.

Brasil (2009, p. 1) acrescenta que a exploração do Ouro em Minas Gerais, no século XVIII muda o panorama da educação colonial. Se até então, o povo estava acostumado a ver o ensino dos ofícios relegado às gentes das mais baixas categorias sociais, a mineração cria a necessidade de um ensino mais especializado destinado aos filhos de homens brancos empregados nas Casas de Fundição e Moedas. Pelo texto, depreende-se que o ensino tinha sexo e cor: homens brancos, descendentes de europeus, desigualdade social (de gênero e étnica) que marcará e continuará a marcar a educação brasileira.

Se Tavares (2012) afirma que não houve o desenvolvimento de educação de cunho profissionalizante no Brasil até 1890, apresentando para isso argumentos baseados na Lei de Terras de 1850 e na Lei Áurea de 1889, por outro lado Brasil (2009) é explícito em afirmar que existiam vestígios de educação profissional no período colonial e no que the sucedeu, mostrando a existência de Centros de Aprendizagem de Ofícios Arsenais da Marinha, os quais tanto traziam trabalhadores oriundos de Portugal quanto faziam recrutamentos de pessoas no Brasil, nem que fossem presos que estivessem em condições de produzir, enviados por chefes de polícia.

Por outro lado, não houve desenvolvimento tecnológico no Brasil, sobretudo pelo Alvará de 1785 que proibiu a existência de fábricas na colônia, o qual só será revogado em 1808 por D. João VI, com a vinda da Família Real Portuguesa para a nova terra e a Criação do Colégio das Fábricas, o qual é considerado o primeiro estabelecimento público que atendia à educação de artistas e aprendizes vindos de Portugal (BRASIL, 2009).

Tavares (2012) associa o início da República Brasileira até o ano de 1955 ao período em que a educação profissional era ofertada como forma de regulamentação social, que atendia à população em estado de vulnerabilidade social, os assim chamados "desvalidos". Brasil (2009, p. 1) aponta que experiências educacionais deste tipo já vinham ocorrendo pelo menos desde o ano de 1800 , e se 
destinavam ao "amparo" da camada menos privilegiada da população por meio do oferecimento de instrução primária a crianças e jovens e aprendizagem de ofícios como "tipografia, encadernação, alfaiataria, tornearia, carpintaria, sapataria dentre outros". Para Tavares (2012), tais políticas se destinavam a tirar a juventude da ociosidade, já que estes "desfavorecidos" aumentavam de forma expressiva a criminalidade e impediam o progresso nacional. A abolição da escravidão ao final do II Reinado trouxe ainda inúmeros ex-escravos e seus descentes, os quais, acostumados com o trabalho nas lavouras e impedidos de ocuparem a zona rural pela Lei de Terras de 1850, passaram a ocupar as periferias dos meios urbanos, demandando uma ocupação nem sempre disponível, ficando, pois, marginalizados. Some-se a isso "pobres, aleijados, cegos, surdos, (...) loucos, órfãos, entre outros marginalizados da época " (TAVARES, 2012) e se observará uma agitação social, cuja contenção viria a se dar pela educação profissional.

Como política pública, esta veio a se consolidar no ano de 1906, com a criação de quatro escolas profissionais no Estado do Rio de Janeiro, pelo seu então Presidente (governador) Nilo Peçanha (BRASIL, 2009). Com a morte do então presidente do Brasil, Afonso Pena, em 1909, Nilo Peçanha expande o projeto das escolas profissionalizantes para todo o território nacional, criando dezenove Escolas de Aprendizes Artífices, destinadas ao ensino primário profissional e gratuito (Brasil, 2009).

De acordo com Brasil (2009, p. 4), a Constituição brasileira de 1937 foi a primeira a tratar especificamente do ensino técnico, profissional e industrial. Cabe destacar, em seu artigo 129, o trecho que afirma: "O ensino pré-vocacional e profissional destinado às classes menos favorecidas é, em matéria de educação, o primeiro dever do Estado" (BRASIL, 1937). Nota-se o caráter assistencialista da educação profissional no Brasil, a qual é destinada às classes menos favorecidas da população, texto que é estampado dentro da própria constituição. Desse modo, a educação para o trabalho fica relegada à coisa de "pobre", sendo que as classes mais favorecidas e privilegiadas da população receberiam o ensino propedêutico. É também em 1937 que as Escolas de Aprendizes Artífices são transformadas em Liceus Profissionais.

Se em 1909, Nilo Peçanha criara escolas que ofertavam ensino primário, somente com a Reforma Capanema a Educação Profissional passou a ser ofertada em nível colegial (o Ensino Colegial correspondia até 1971 ao que hoje é o Ensino 
Médio), sendo o ingresso nos estabelecimentos de ensino realizado por meio de exames de admissão. Foi somente em 1942 que a Educação Profissional fora integrada à estrutura educacional da nação, ficando os alunos formados nos cursos técnicos autorizados a cursar o nível superior em área equivalente à de sua formação (BRASIL, 2009, p. 4).

Na terceira fase, que se inicia na década de 1950, empresas multinacionais se instalam no Brasil, o que aumenta a demanda por trabalhadores qualificados (TAVARES, 2012, p. 5). A educação passou a se alinhar ao plano de metas estabelecido no governo $\mathrm{JK}$, formando profissionais para promover o desenvolvimento da nação, tirando-a do seu atraso e subdesenvolvimento (BRASIL, 2009, p 4). De acordo com Tavares (2012, p. 5), tal formação se deu por meio da Teoria do Capital Humano ${ }^{5}$, com a influência de modelos e ideias estrangeiras na educação nacional, já que o "Brasil torna-se, (sic) dependente do capital internacional, que passa a requisitar investimentos na qualificação de mão-de-obra”. Brasil (2009, p. 4) afirma que em 1959 as Escolas Industriais Técnicas se transformam em autarquias que ganham autonomia didática e de gestão, agora sob o nome de Escolas Técnicas Federais.

Com o Governo Militar, a Educação Profissional ganha ainda a função de servir como meio de promoção da educação dos meios populares, ansiosos por obter qualificação de nível superior. Como os militares achavam perigoso ampliar o acesso da população à Universidade, o que representava o risco de se agravarem os movimentos de contestação ao Regime, a educação técnica serviu mais como forma

\footnotetext{
${ }^{5}$ De acordo com Lombardi et al. (2006), a Teoria do Capital Humano se deve ao início dos estudos da disciplina Economia da Educação nos EUA, por volta da década de 1950. O principal formulador da Teoria do Capital Humano foi o teórico Theodore W. Schultz, considerado um dos fundadores da disciplina. Os estudos de Economia da Educação resultaram da preocupação em se explicar como o "fator humano" da produção interfere nos ganhos de produtividade. Neste sentido, conclui-se que a qualificação educacional para o trabalho se torna o maior fator que contribui para a ampliação da produtividade econômica, aumentando os lucros do capital. No campo da educação, essas concepções geraram a concepção tecnicista de ensino. "Sob a predominância desta visão tecnicista, passou-se a disseminar a ideia de que a educação é o pressuposto do desenvolvimento econômico, bem como do desenvolvimento do indivíduo, que, ao educar-se, estaria "valorizando" a si próprio, na mesma lógica em que se valoriza o capital" (LOMBARDI et al., 2006). Lombardi et al (2006) destacam a lógica perversa embutida nessa concepção de educação ao disseminar-se que esta é o pressuposto do crescimento econômico e do desenvolvimento do indivíduo, de modo que este, ao educar-se estaria em processo de valorizar-se a si próprio, "na mesma lógica em que se valoriza o capital". Para Lombardi et al (2006), esta teoria "deslocou para o âmbito individual os problemas da inserção social, do emprego e do desempenho profissional e fez da educação um 'valor econômico', numa equação perversa que equipara capital e trabalho como se fossem ambos igualmente meros 'fatores de produção' (...). Além disso, legitima a ideia de que os investimentos em educação sejam determinados pelos critérios do investimento capitalista, uma vez que a educação é o fator econômico considerado essencial para o desenvolvimento".
} 
de aliviar a demanda por vagas universitárias do que para qualificar mão-de-obra para a indústria (TAVARES, 2012, p. 6). Pedagogicamente, houve o desenvolvimento e ampliação da didática tecnicista, a qual se alinhava aos objetivos propostos pela Teoria do Capital Humano.

Sob a vigência do Regime Ditatorial no Brasil, a Lei de Diretrizes e Bases da Educação Brasileira - LDB/1971 tornou técnico-profissional, compulsoriamente, todo o ensino secundário (atual Ensino Médio) brasileiro (BRASIL, 2009, p. 5). Tavares (2012, p. 6) é claro em afirmar que os objetivos, não atingidos, dessa medida eram igualar a educação estatal ofertada a ricos e pobres no Brasil. Não podemos nos esquecer que a Constituição de 1937 previa ensino profissionalizante para as camadas mais pobres da população em detrimento do ensino propedêutico, que era ofertado para as classes elitistas e dominantes.

Tais objetivos de equiparação entre o ensino ofertado para diferentes camadas de população não fora atingido.

Contudo, a falta de condições materiais para concretizar tal objetivo fez com
que esta Lei ampliasse ainda mais as diferenças entre as escolas de ricos e
pobres e a distância entre educação propedêutica e profissional. Enquanto
as instituições de ensino que antes desta Lei já haviam se especializado na
oferta de cursos técnicos conseguiram oferecer educação de qualidade,
outras continuavam a ofertar ensino propedêutico disfarçado de
profissionalizante. Mas a grande maioria não deu conta de atender a nenhum
dos propósitos do ensino secundário, nem propedêutico, nem
profissionalizante. Mesmo sem admitir formalmente o fracasso da Lei
$5.692 / 71$, o Estado resgata a possibilidade das (sic) escolas fazerem a opção
entre a oferta de ensino propedêutico ou técnico-profissionalizante, por meio
da Lei 7.044/82. Apesar de anunciada, a criação de uma escola única para
todos, que unificasse educação propedêutica e profissional não se
concretizou neste período (TAVARES, 2012, pp. 6-7).

Observa-se, pois, neste período que vai de 1950 ao fim do Regime Militar em 1985, no Brasil, a primeira grande expansão da educação técnica de nível profissionalizante, o que contrasta com o período de estagnação por ela vivenciada nos anos de implantação da política neoliberal (décadas de 1980 e 1990). Foi ainda sob a vigência da ditadura militar que se transformaram três das Escolas Técnicas Federais em Centros Federais de Educação Tecnológica - CEFETs (Paraná, Minas Gerais e Rio de Janeiro) com o objetivo de formar mais engenheiros e tecnólogos, o que se estenderá mais tardiamente às demais instituições (BRASIL, 2009, p. 5).

Os CEFETs ainda hoje ocupam o imaginário da população. Quando se fala, contemporaneamente, em educação técnica de qualidade, a maior parte da população 
faz referência ao ensino que fora ofertado nestes centros. Símbolos de excelência em termos de educação profissionalizante, os CEFETs foram sendo criados, gradativamente, pela transformação das Escolas Técnicas Federais e das Escolas Agrotécnicas Federais por meio da Lei no 8948 de 1994.

Com o fim do Regime Militar, o processo de redemocratização do Brasil se deu por meio da política neoliberal. Tavares $(2012$, p. 7) mostra que enquanto houve ampliação da educação profissional ofertada pela iniciativa privada, houve estagnação da oferta de educação técnica pública e gratuita, o que se alinhava aos objetivos de reduzir os gastos públicos em educação, ao mesmo tempo em que se desejava o aparelhamento empresarial desta modalidade de ensino pela rede privada. Isso mostra claramente o projeto de Estado mínimo do neoliberalismo, com o enxugamento da máquina pública, principalmente sob os anos de governo Fernando Henrique Cardoso (FHC).

Para Tavares (2012):

Cabe à Educação Profissional formar o "trabalhador de novo tipo", em sintonia com as novas formas de organização e gestão do trabalho e com os interesses do mercado. Contudo, transfere-se para o próprio trabalhador a responsabilidade pelo domínio das competências profissionais exigidas pelo mercado e, portanto, pela sua empregabilidade (TAVARES, 2012, p. 8).

Durante o governo FHC, por meio do Decreto nำ 2208 de 1997, são criadas matrizes curriculares e matrículas distintas para os estudantes da educação técnica: uma no ensino propedêutico e outra na modalidade técnica, as quais poderiam ocorrer tanto em época, quanto em instituições diferentes. O caráter dualista do ensino profissionalizante, promovido na era FHC, representa uma lógica perversa de exclusão da classe trabalhadora de maiores políticas de acesso à educação pública gratuita e de qualidade e tinha o claro objetivo de baratear os custos dos cursos técnicos ofertados, principalmente para o empresariado. Tais cursos passaram a ser apenas uma complementação ao ensino propedêutico já ofertado. As mudanças ainda pretendiam promover alterações estruturais no ensino técnico que levassem a uma formação de um número expressivo de profissionais em curto espaço de tempo mediante currículos flexíveis, o que teria ainda como consequência o fato de que os CEFETs formariam técnicos que ingressassem diretamente no mercado de trabalho, em vez de ingressarem no Ensino Superior, o que contribuiria para diminuir a pressão 
pelo incremento do número de vagas em nível de graduação, diminuindo os investimentos do Estado em educação (TAVARES, 2012, p. 8).

Para Pereira (2003, p. 100):

\begin{abstract}
A Reforma da Educação Profissional dos anos 1990, como já mencionamos, parte de algumas premissas falsas e acentua o seu equívoco não na "separação" do caráter profissionalizante do propedêutico no currículo, mas no fato de não ter formulado a sua política ocupando-se preliminarmente de estudos mais consistentes dos atuais processos de trabalho. É possível para alguns processos menos complexos que o conteúdo profissionalizante não desloque ou diminua a presença dos conteúdos não-profissionalizantes, o que dificilmente ocorreria se o objetivo é a qualificação para processos mais complexos. Em nossa opinião, é fundamental que seja assegurada a integralidade do conteúdo da escola básica, conteúdo propedêutico, ou seja, que introduz, que é preliminar, que prepara para receber a formação completa, neste caso profissionalizante. Um outro equívoco da reforma se coloca no campo do pequeno envolvimento e capacitação dos professores e especialistas das unidades de ensino (PEREIRA, 2003, p. 100).
\end{abstract}

A fase de estagnação pode ser caracterizada, principalmente, por um dispositivo legal presente no art. 3ํㅗ $§ 5^{\circ}$ da Lei 8948 de 1994, o qual representava um entrave à expansão da Rede Federal ao determinar que a criação de novas unidades de ensino somente poderia acontecer mediante parceria da União com Estados, Municípios, Distrito Federal, setor produtivo e organizações não governamentais.

Mediante as inúmeras exigências apresentadas neste parágrafo da legislação, quase não houve a criação de nenhuma unidade, exceto algumas Unidades de Ensino Descentralizadas - UNEDs, as quais se implementaram em prédios que já se encontravam em condições de funcionamento e que deveriam ser, pois, aproveitados.

No início do século XXI, observaram-se políticas de ampliação do estado de bem-estar social no Brasil, o que redundou numa postura mais progressista em relação à Educação. Nesse sentido, a Educação Profissional passa por um novo ciclo de expansão, sendo que um conjunto de leis e decretos federais reorganizou o ensino técnico e tecnológico no país. A dualidade entre ensino técnico e propedêutico foi reduzida por meio do Decreto no 5154 de 2004, o qual permitia novamente a integração entre o ensino técnico ao Ensino Médio (BRASIL, 2009, p. 5). Criou-se também a primeira Universidade Federal Tecnológica do país, por meio da transformação do CEFET Paraná em universidade.

De acordo com Tavares (2012, p. 11), a legislação, "responsável pelo 'congelamento' da Rede Federal vigorou até o ano de 2005, quando o governo Lula 
da Silva [a] substituiu, através da Lei 11.195". Trata-se da Lei no 11195 de 2005, a qual alterou a redação da palavra "somente" por "preferencialmente". Para Tavares (2012, pp. 11-12) esta alteração representou um marco histórico que propiciou a retomada da expansão da Rede Federal, com a constituição de um plano que permitisse operacionalizar esta empreitada, o qual a dividiu em duas fases, já concluídas, com um investimento previsto de $R \$ 1,1$ bilhões.

De toda a legislação que passou a regulamentar o ensino técnico e tecnológico no país, cabe destacar a Lei Federal nำ 11892 de 2008, a qual instituiu a Rede Federal de Educação Profissional, Científica e Tecnológica ao mesmo tempo em que criava os Institutos Federais de Educação, Ciência e Tecnologia (IFs), resultado do rearranjo, reorganização, fusão e expansão das antigas escolas técnicas e agrotécnicas, as quais passaram a constituir uma única autarquia.

Pela Lei no 11892 de 2008, criaram-se 38 Institutos Federais em todo 0 território nacional. Enquanto alguns Estados ganharam mais de um Instituto, como a Bahia ou Goiás, por exemplo, o Estado do Piauí recebeu apenas um. Dentre todos os entes federados, Minas Gerais foi aquele que recebeu o maior número de Institutos, num total de cinco. Para Brasil (2009), ao citar o Plano de Desenvolvimento da Educação (PDE), de 2007, a criação dos Institutos Federais representou a necessária integração entre a oferta de educação profissional e tecnológica e o desenvolvimento local e regional.

Espera-se ainda a execução da terceira fase de expansão da Rede Federal na década de 2011-2020 com a implantação de 86 novos campi de Instituto Federal. Destes, 46 são remanescentes da segunda fase de expansão da Rede (TAVARES, 2012, p. 15). Cabe destacar que se espera, como resultado desta política, que existam Institutos Federais presentes em um quinto do total de municípios brasileiros existentes.

Tavares (2012, p. 16) traz ainda a importante fala da presidente Dilma Rousseff em seu programa de rádio "Café com a Presidenta", o qual fora transmitido em 22 de agosto de 2011, sobre os critérios de distribuição dos campi do IF pelo país.

Utilizamos vários critérios para fazer esta seleção [...]. Primeiro, demos prioridade a municípios com mais de 50 mil habitantes, em microrregiões onde não existiam escolas da rede federal e no interior do Brasil. Segundo, tivemos a preocupação [...] de atender municípios com elevado percentual de extrema pobreza. Terceiro [...] focamos em um grupo de municípios que têm mais de 80 mil habitantes, mas, nos quais, a prefeitura, muitas vezes, 
arrecada pouco e tem muita dificuldade de investir em educação (ROUSSEF, $2011)^{6}$.

Desse modo, a retomada de expansão da Educação Profissional no século XXI representou uma política educacional sem precedentes na história do Brasil, atribuindo novo sentido aquilo que antes era apenas considerado uma forma de ocupar os pobres e desvalidos da nação. Para Tavares (2012, p. 9), o "diferencial em relação às universidades, segundo a SETEC (Secretaria de Educação Profissional Tecnológica), é a priorização da oferta de cursos superiores de licenciatura (formação de professores) e cursos de bacharelado e de tecnologia em áreas consideradas estratégicas, do ponto de vista econômico".

As metas de expansão estabelecidas pelo Governo Lula (2003 a 2010), entre outras coisas, previam um aumento de $400 \%$ das unidades construídas, que passariam de 140 escolas, em 2003, para um total de 562, em 2014. Segundo site do Ministério da Educação, foram investidos mais de $\mathrm{R} \$ 3,3$ bilhões entre os anos de 2011 e 2014. Das 208 novas unidades previstas para o período, todas foram construídas e entraram em funcionamento, totalizando 562 escolas em atividade atualmente, conforme a Figura 2.

Figura 2- Cenário evolutivo da RFEPCT

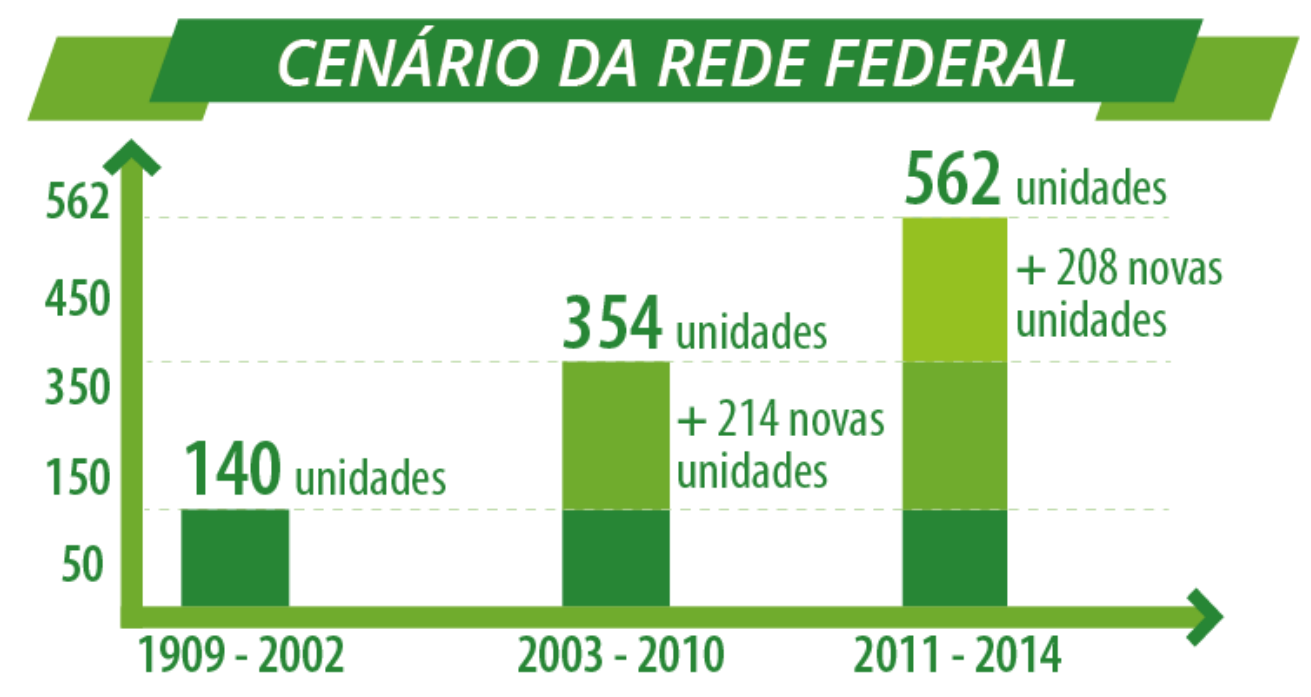

Fonte: MEC, 2014.

\footnotetext{
${ }^{6}$ A transcrição desta entrevista pode ser encontrada no sítio <http://cafe.ebc.com.br/cafe/arquivo/mais-vagasno-ensino-superior-e-profissional-para-os-estudantes-brasileiros> cujo acesso ocorreu em 2 nov. 2015.
} 
A criação da Rede Federal de Educação Profissional Tecnológica, dos IFs, e a forma como expandiram representaram uma política pública bem abrangente, pois além de cobrir todo o território nacional, ousou ou arriscou na criação de uma rede com tantas características incomuns, destacando as configurações próprias, locais que valorizam a vocação regional dos lugares em que cada campus se instalou, desenvolvendo-os. Para finalizar:

Os desafios que se apresentam à expansão da Rede Federal de Educação Profissional e Tecnológica exigem que o Brasil assuma a Educação Profissional como política de Estado, de modo a garantir a sua continuidade com a sucessão deste governo pelos próximos. Sem dúvida, a expansão da Rede Federal da forma como vem sendo executada é algo sem precedentes na história do Brasil. Contudo, alguns aspectos desse processo ainda precisam ser analisados com mais cuidado (TAVARES, 2012, p. 17).

\subsubsection{Configurações dos Institutos Federais de Educação, Ciência e Tecnologia}

Os Institutos Federais são instituições que apresentam uma estrutura diferenciada, uma vez que foram criados pela transformação e agregação de antigas instituições de educação profissional, com a posterior criação de novos campi e sua expansão pelas cidades do interior dos Estados. Segundo a Lei oํ 11892 de 2008, em seu art. $2^{\circ}$ estabelece que:

Os Institutos Federais são instituições de educação superior, básica e profissional, pluricurriculares e multicampi, especializados na oferta de educação profissional e tecnológica nas diferentes modalidades de ensino, com base na conjugação de conhecimentos técnicos e tecnológicos com as suas práticas pedagógicas, nos termos desta Lei (BRASIL, 2008).

A política pública que cria os Institutos Federais (IFs) foi uma resposta às demandas por formação e qualificação para o trabalho,

[...] deve ser destacado que os IF possuem como objetivo alcançar todos os segmentos da mão de obra nacional, possuindo um leque de cursos que variam desde a formação continuada e inicial, em que a exigência acadêmica é baixa, até cursos de mestrado (TCU, 2013, p.4). 
Com o desenvolvimento científico e tecnológico, a sociedade, por meio de suas instituições, busca se adaptar e adequar às mudanças na economia e às profundas transformações pelas quais passa o mundo do trabalho. Tais mudanças pressupõem modificações na formação do trabalhador, haja vista às novas especificidades requeridas de atuação profissional e as várias necessidades de domínio técnico, pelas quais as profissões assumem novas configurações chegando à estrutura profissionais diversas. Segundo Carvalho (2003):

\begin{abstract}
A estrutura das profissões é, especialmente afetada pela introdução das tecnologias de informação e que a modifica de duas maneiras. A primeira modificação é oriunda da utilização dessas novas tecnologias de informações em tarefas rotineiras e pouco complexas. Nesse caso a automatização afeta de forma significativa os empregos de baixa qualificação, com repercussões importantes na economia de mão-deobra, uma vez que a produtividade no setor levará a redução de empregos não-qualificados (CARVALHO, 2003, p.68).
\end{abstract}

Cabe destacar que a linha de montagem com robotização e automação tem perdido espaço para produção integrada, modificações que se fazem presentes ainda nos modelos de gestão e manutenção. Neste sentido, os IFs têm um papel determinante na formação do trabalhador, pois se constituem em elo de ligação entre a tecnologia com novas necessidades do mundo do trabalho e o trabalhador que ainda se encontra com baixa qualificação. Cabe, pois, aos Institutos Federais propiciar maneiras de formá-lo e qualificá-lo, de modo que possa ocupar e desempenhar diferentes funções em seus postos de trabalho, utilizando-se ainda de recursos tecnológicos.

A outra modificação que sofre a estrutura das profissões está relacionada à
possibilidade que essas novas tecnologias de informação portam de permitir
a distribuição das unidades de produção de pequena escala, seja para bens
ou serviços. Essa tendência aponta para uma organização do trabalho menos
hierárquica, com aumento da participação do trabalhador na empresa e para
a polivalência, refletindo, sobretudo, nos níveis de qualificação médios e,
portanto, afetando a estrutura tradicional, que é baseada num número de
trabalhadores não-qualificados e semiqualificados (CARVALHO, 2003, p.68).

Ocupando postos de trabalho organizados por meio de uma hierarquia mais flexível, o trabalhador não só demandará o domínio das TICs, para a realização de suas funções, como também, de uma formação mais completa em termos de desenvolvimento de competências pessoais e profissionais. Segundo Pacheco (2012), faz parte da missão dos IFs a busca de soluções técnicas e de novas 
tecnologias que respondam às demandas crescentes por formação técnica profissional e por difusão de conhecimentos científicos.

Neste sentido, reafirmamos o conteúdo do art. 2ํ da Lei nํㅜ 11892 de 2008, o qual afirma que os Institutos Federais de Educação, Ciência e Tecnologia que constituem a Rede Federal de Educação Profissional, Científica e Tecnológica possuem objetivos dentre os quais se destacam: ministrar educação profissional técnica de nível médio, priorizando cursos integrados, para os concluintes do ensino fundamental e para o público da educação de jovens e adultos, ministrar cursos de formação inicial e continuada de trabalhadores, com vistas à capacitação, o aperfeiçoamento, a especialização e a atualização de profissionais, em todos os níveis de escolaridade, nas áreas da educação profissional e tecnológica, realizar pesquisas aplicadas estendendo seus benefícios à comunidade; e desenvolver atividades de extensão, em articulação com o mundo do trabalho e os segmentos sociais com ênfase na produção, desenvolvimento e difusão de conhecimentos científicos e tecnológicos.

A concepção de educação aliada à tecnologia se torna um apelativo de aceitação da nova política educacional de formação profissional técnica, uma vez que o termo tecnologia, no senso comum, representa desenvolvimento, qualidade de vida, modernidade, inovação, enfim, uma expressão carregada de significados atrativos na atualidade. Sem dúvida, pode-se compreender que aliar ensino, pesquisa e extensão à tecnologia é de importância fundamental para que se tenha êxito na educação de nosso tempo. Mas, segundo Lima (2005), está havendo uma descontextualização do conceito de tecnologia em relação aos "contextos e sujeitos sociais", com disseminação de discursos tecnocráticos, que legitimam políticas públicas conservadoras e excludentes, relegando aos "cidadãos o papel de meros consumidores". Parece óbvio que conceituar tecnologia é necessário para compreensão da natureza dos Institutos Federais de Educação, Ciência e Tecnologia, haja vista, que se tratar de um dos fundamentos de constituição destas instituições, o cerne de sua existência. Lima (2005) observa que o conceito de tecnologia tomado de forma isolada é tendencioso e falacioso, porque não se trata de dizer o que é, mas de relacioná-lo uma conjuntura que deve, pois, ser considerada. Então, a 
posto que a relação da tecnologia com as classes sociais é profundamente desigual sob a hegemonia das relações capitalistas, considerando-se as desiguais formas de acesso e propriedade de condições materiais e intelectuais nessa sociedade (LIMA, 2005, p.27).

Para Veraszto (2008), conceituar tecnologia é um tanto difícil, já que se trata de um conceito vasto e que evoluiu ao longo da história. Na tentativa de apresentar uma definição para o termo, o autor estabeleceu que:

(...) a tecnologia como um conhecimento prático derivado direta e exclusivamente do desenvolvimento do conhecimento teórico científico através de processos progressivos e acumulativos, onde teorias cada vez mais amplas substituem as anteriores. Nessa perspectiva a tecnologia é um conhecimento prático (pelo menos desde o final do século XIX) derivado diretamente da ciência, do conhecimento teórico (VERASZTO, 2008, p. 67).

Moran (2003, p.1-2) de forma até simplista afirma que tecnologia "são os meios, os apoios, as ferramentas" que são úteis à sociedade, em diferentes espaços. Assim, há que se considerar que a tecnologia não está à disposição da sociedade como um mero recurso útil e que transforma o dia-a-dia numa travessia rápida e segura dos afazeres diversos que o homem desenvolve. Sem dúvida é um tipo de conhecimento, que se materializa e pode contribuir para alienação e para expressão do pensamento crítico, vai depender do ator de manipulação.

\subsubsection{Objetivos da Rede Federal de Educação Profissional Científica e Tecnológica}

A educação pode, por meio de suas especificidades democratizar o acesso à tecnologia e diminuir as barreiras sociais. Por meio dela pode-se até desenvolver, aprimorar e criar novas tecnologias úteis ao homem em seu processo de subsistência e produtividade. Neste sentido, faz-se necessário um alinhamento entre uma política consistente e coerente adequada à realidade de cada instituição de ensino que se propõe aliar a tecnologia e ensino. Os Institutos Federais podem agregar todas essas especificidades? É preciso uma análise das finalidades e características,

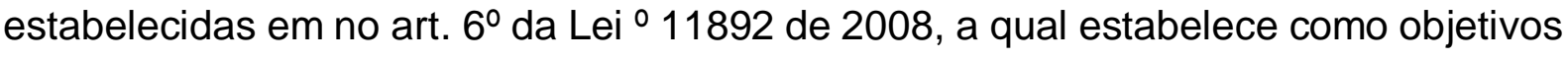
para os Institutos Federais: 
I - ofertar educação profissional e tecnológica, em todos os seus níveis e modalidades, formando e qualificando cidadãos com vistas na atuação profissional nos diversos setores da economia, com ênfase no desenvolvimento socioeconômico local, regional e nacional.

II - desenvolver a educação profissional e tecnológica como processo educativo e investigativo de geração e adaptação de soluções técnicas e tecnológicas às demandas sociais e peculiaridades regionais (Brasil, 2008, Art. 6ㅇ).

Segundo as finalidades e características definidas neste documento legal, a educação profissional tecnológica é o cerne da atuação dos IFs, distribuída em todos os seus níveis e modalidades e com a intensão de estabelecer relação com demandas regionais, locais, dialogando com os arranjos produtivos sem se esquivar dos avanços tecnológicos e das necessidades de qualificação impostas pelo mercado trabalho. Para dimensionar a amplitude de atuação que foi definida para os IFs, cabe detalhar o que seria a educação profissional, especificar níveis e modalidades, bem como identificar o procedimento de ligação da tecnologia com a formação do indivíduo e, por conseguinte com as demandas, sejam elas locais ou regionais. A educação profissional, segundo Christophe (2005), é uma expressão genérica que diz respeito a vários procedimentos educativos de formação, capacitação e qualificação profissional.

O art. 40 da Lei o 9394 de 1996 estabelece que a "educação profissional será desenvolvida em articulação com o ensino regular ou por diferentes estratégias de educação continuada, em instituições especializadas ou no ambiente de trabalho" (BRASIL, 1996). No entanto, o Decreto № 2.208 de 17 abril de 1997, estabeleceu uma especificação para os níveis da educação profissional, conforme se observa em eu art. $3^{\circ}$ :

Art. 3․ A educação profissional compreende os seguintes níveis:

I - Básico: Destinado à qualificação e reprofissionalização de trabalhadores, independente de escolaridade prévia;

II - Técnico: Destinado a proporcionar habilitação profissional a alunos matriculados ou egressos do ensino médio, devendo ser ministrado na forma estabelecida por este Decreto;

III - Tecnológico: corresponde a cursos de nível superior na área tecnológica, destinados a egressos do ensino médio e técnico.

Art. 10을 Os cursos de Nível Superior, correspondentes à educação profissional de nível tecnológico, deverão ser estruturados para atender aos diversos setores da economia, abrangendo áreas especializadas, e conferirão diploma de tecnólogo (BRASIL, 1997).

O inciso terceiro do art. 6 da Lei ํㅜ 11892 de 2008 defende que a educação básica seja verticalizada e integrada à educação profissional e superior, o que 
corresponderia um processo de otimização da infraestrutura física, pessoal e recursos (BRASIL, 2008). Já no inciso quarto da mesma lei estabelece que os IFs devem orientar sua oferta de modo a beneficiar a consolidação e o fortalecimento dos arranjos produtivos, sociais e culturais locais.

A verticalização do ensino é uma característica imposta aos institutos, que os possibilita ofertar níveis educacionais diferenciados: o Ensino Médio, última etapa da Educação Básica, deverá ser integrado à formação técnica, cujas habilidades e competências poderão ser aprofundadas mediante o ingresso em cursos dentro da mesma área de nível superior e de pós-graduação. O Decreto no 5.154 de 2004, também especifica que o Ensino Técnico poderá ser cursado de forma Concomitante, ou seja, o aluno que já tenha concluído o Ensino Fundamental ou cursando o Ensino Médio, mesmo em outra instituição, pode obter a formação técnica dentro de um Instituto Federal, ocupando turnos e matrículas diferentes. Outro percurso formativo possível é a formação técnica obtida de modo Subsequente. Tal a formação técnica é ofertada aos alunos que já concluíram o Ensino Médio. Sobre o Ensino Superior, os Institutos devem ofertar, preferencialmente, cursos de tipo Tecnológicos, Licenciaturas, Engenharias; podendo ainda atuar até a Pós-Graduação (Latu Sensu, Stricto Sensu), nas modalidades presencial e à distância, por meio de programas e plataformas como exemplifica o moodle ${ }^{7}$, além de poder ofertar a EJA (Educação de Jovens e Adultos), e ainda cursos FIC (Formação Inicial e Continuada). A verticalização do ensino, ligando o ensino médio - Educação Básica ao técnico e ao ensino Superior e ainda à pós-graduação, deve ocorrer respeitando os eixos tecnológicos de atuação de cada Campus. Por Eixos Tecnológicos, compreendemos que tratam de

(...) matrizes tecnológicas, que perpassa transversalmente e sustenta a organização curricular e a identidade dos cursos, imprimindo a direção dos seus projetos pedagógicos". As matrizes tecnológicas podem ser compreendidas como os arranjos lógicos constituídos pelas bases tecnológicas de um curso, que, por sua vez, são os ingredientes tecnológicos básicos de uma formação. Cada eixo tecnológico acolhe vários tipos de técnicas, mas não se restringe a suas aplicações, relacionando-se também a outras dimensões socioeconômicas (PACHECO, 2010, p.16).

\footnotetext{
${ }^{7}$ Moodle é o acrónimo de "modular object-oriented dynamic learning environment", um software livre, de apoio à aprendizagem, executado num ambiente virtual. Fonte: Wikipédia, a enciclopédia livre.
} 
Ainda os IFs tem como objetivos constituírem-se em centro de excelência na oferta do ensino de ciências, em geral, e de ciências aplicadas, em particular, estimulando o desenvolvimento de espírito crítico, voltado à investigação empírica, bem como qualificar-se como centro de referência no apoio à oferta do ensino de ciências nas instituições públicas de ensino, oferecendo capacitação técnica e atualização pedagógica aos docentes das redes públicas de ensino, desenvolver programas de extensão e de divulgação científica e tecnológica, realizar e estimular a pesquisa aplicada, a produção cultural, o empreendedorismo, o cooperativismo e o desenvolvimento científico e tecnológico e ainda, promover a produção, o desenvolvimento e a transferência de tecnologias sociais, notadamente as voltadas à preservação do meio ambiente (Pacheco, 2010).

É imperativo aos IFs aliar todos os cursos que ofertam às demandas regionais, às quais são atendidas graças a sua capilaridade, por meio de sua estrutura multicampi, cuja penetração pelo interior do país é hoje uma realidade. Desse modo, é possível aos Institutos dialogar com as necessidades das comunidades, na busca de uma construção de projeto institucional que coaduna com a formação e desenvolvimento local. Dowbor (2002) afirma que a ideia de educação para o desenvolvimento local está diretamente vinculada à necessidade de se formar pessoas que possam, no futuro, participar de forma ativa das iniciativas capazes de transformar o seu entorno, criando e recriando caminhos para o bem-estar coletivo. De acordo com o documento da SETEC (Brasil, 2010), essa especificidade dos Institutos se traduz na possibilidade de:

Atuar no sentido do desenvolvimento local e regional na perspectiva da
construção da cidadania, sem perder a dimensão do universal (...). O diálogo
vivo e próximo dos Institutos Federais com a realidade local e regional
objetiva provocar um olhar mais criterioso em busca de soluções para a
realidade de exclusão que ainda neste século castiga a sociedade brasileira
no que se refere ao direito aos bens sociais e, em especial, à educação. No
local e no regional, concentra-se o universal, pois nada no mundo seria em
essência puramente local ou global (CONCEPÇÕES E DIRETRIZES, SETEC
2010, p.20).

A atuação no contexto local não compreende somente o ensino, a pesquisa e a extensão. Também fazem parte do bojo de atribuições e especificidades dos IFs, de modo que esta atuação 
[...] está associada à conduta articulada ao contexto em que está instalada; ao relacionamento do trabalho desenvolvido; à vocação produtiva de seu lócus; à busca de maior inserção da mão de obra qualificada neste mesmo espaço; à elevação do padrão do fazer de matriz local com o incremento de novos saberes, aspectos que deverão estar consubstanciados no monitoramento permanente do perfil socioeconômico-político-cultural de sua região de abrangência (CONCEPÇÕES E DIRETRIZES, SETEC 2010, p.22).

Segundo Dowbor (2002), é necessário redescobrir o manancial de conhecimentos que existem em cada região, valorizá-los, e transmiti-los de forma organizada para as gerações futuras. Conhecimentos técnicos são importantes, mas têm de ser ancorados na realidade em que as pessoas vivem, de maneira a serem apreendidos na sua dimensão mais ampla.

Para Dowbor (2002):

[...] o que visamos é uma escola um pouco menos lecionadora, e um pouco mais articuladora dos diversos espaços do conhecimento que existem em cada localidade, em cada região. E educar os alunos de forma a que se sintam familiarizados e inseridos nesta realidade. Isso significa promover a valorização do território e dos recursos locais (naturais, econômicos, humanos, institucionais e culturais), que constituem o potencial local de melhoria da qualidade de vida para todos. É preciso conhecer melhor este potencial, para chegar à modalidade de desenvolvimento sustentável adequada à situação local, regional e planetária (DOWBOR, 2002, p.22.).

Na análise de Otranto (2010) da Lei no 11.892 de 2008, onde se estabelece que os Institutos de Educação Profissional, além de vários outros níveis, devem também ofertar o ensino superior, esta legislação se traduz mais em uma tentativa de implantar um modelo alternativo à "universidade de pesquisa" que já vem sendo implantada nos últimos anos na América Latina, por incentivo do Banco Mundial.

Na proposta político-educacional-financeira do Banco Mundial de criação de instituições de educação superior que tenham custos inferiores aos das universidades, no que se refere aos cursos superiores técnicos, ganha especial destaque a alegação de que estes cursos seriam mais flexíveis, portanto mais integrados ao sistema produtivo, e de menor custo que o universitário tradicional. São ideias que, no Brasil, contam com o incentivo e a anuência dos planejadores da educação, que vêm consolidando esse modelo através de instrumentos legais (OTRANTO, 2010, p.14).

Nesse sentido, o pensamento de Otranto (2010) permite-nos afirmar que a estratégia neoliberal a qual o Banco Mundial representa consiste na criação de postos de educação mais baratos, que ofereçam uma formação mais aligeirada, menos sólida e com conteúdos mais rasos, caso de cursos superiores tecnológicos encontrados em 
inúmeras instituições que se parecem uma versão menor de outras formações do tipo bacharelado. Há de se destacar, no entanto, que graças aos IFs, ofertar o ensino superior no Brasil, hoje, não é mais exclusividade das universidades. Sendo os Institutos instituições multicampi, sua atuação é múltipla e leva o ensino superior a lugares longínquos das capitais, antes desprovidos de qualquer tipo de investimentos por parte do governo federal. Outrora focados na formação profissional técnica, sucumbiram à sua missão precípua, agregando demandas educacionais que não representam o seu perfil institucional histórico e assim, perderam parte de sua identidade, passando a responder as imposições mercadológicas.

\begin{abstract}
A forma como está estruturado o IFET prevê otimização dos custos, e total controle da nova instituição, o que pode acarretar uma fiscalização e um direcionamento mais eficaz na subordinação da educação por ela ministrada aos interesses do mercado, que deve ser fiscalizado desde já pelos docentes, discentes e técnicos dos Institutos Federais. A observação deve ser feita nos vários níveis de ensino, uma vez que a disseminação ideológica, de que a educação deve subordinar-se à lógica do mercado, pode começar bem cedo, na educação básica, principalmente no ensino médio (OTRANTO, 2010, p.15).
\end{abstract}

Tendo como norte a economia e a política do Brasil, nas constatações de Souza (2006), percebe que o neoliberalismo, tem impregnado o discurso de qualidade na educação, alegando haver uma falência no sistema público de ensino. Neste sentido, pessoas alinhadas ao discurso neoliberal vêm fazendo muita pressão no meio acadêmico, tentando impor uma agenda cujo conteúdo se encontra impregnado de conceitos empresariais tais como qualidade total, eficiência, eficácia, desenvolvimento de habilidades, competências.

[...] educação é concebida apenas como uma instituição que qualifica pessoas para a ação na esfera econômica, sendo esta ação restrita ao mercado de trabalho. Desse modo, os trabalhadores buscam na sua qualificação saídas para ingressarem nesse mercado de trabalho cada vez mais competitivo e são estimulados a procurar a educação como forma de valorizar sua empregabilidade (SOUZA, 2006, p.45).

De acordo com a LDB, Lei no 9394 de 1996, em seu art. 39 se estabelece que: "A educação profissional, integrada às diferentes formas de educação, ao trabalho, à ciência e à tecnologia, conduz ao permanente desenvolvimento de aptidões para a vida produtiva" (BRASIL, 1996). Fica, pois, evidenciado neste trecho a ideologia de que a formação que deve ser ofertada nos IFs é para o trabalho, 
capacitar para executar uma tarefa, visão que atende ás necessidades do capitalismo ou seja, formação de mão-de-obra, travestido do apelo ao atendimento das demandas tecnológicas e sociais, que, por sua vez respondem à globalização. Na concepção de Soares (2014), "a educação profissional desvia-se do sistema educacional e cada vez mais se aproxima do sistema produtivo, adequando-se totalmente a ele".

A educação pode ser vista como o caminho para autonomia pensante do indivíduo, visto que o instrumentaliza para que tenha uma visão real do mundo que o cerca e assim, poder agir pelo bem-estar social na perspectiva da cidadania, mas ao mesmo tempo, a educação pode ser instrumento de manobra para reforçar hegemonia de poder do Estado e ou manter e ainda fortalecer estruturas mercadológicas. A educação profissional, que é vista como mero mecanismo de qualificação do trabalhador, necessita dialogar com o conhecimento teórico crítico, para haver uma certa emancipação no processo de formação do indivíduo. Buscar uma forma inovadora, criativa de trabalhar a teoria, sendo crítica e autônoma, aliada a uma prática diferenciada, que agregar os conhecimentos científicos às peculiaridades regionais é um desafio para o ensino profissional. Para tanto, há que se pensar no modelo de gestão e no seu papel, como o elo de ligação entre o ideal e real na formação profissional.

\subsubsection{Gestão de Ensino}

O ensino é uma dimensão que centraliza esforços institucionais, por ser a que mais está relacionada ao objetivo principal das instituições educacionais e também a que sofre a maior cobrança objetiva nas avalições que se realizam, tanto as de âmbito externo, bem como as de foro interno. Ensinar, poderíamos afirmar, sem esgotar as inúmeras possibilidades de definição do termo, é um processo que objetiva promover a aprendizagem dos mais variados assuntos, conceitos, ciências, ajustando-se a contextos diferenciados de tempo, espaço, cultura, de modo que se delimite o que, o como e o porquê ensinar.

No contexto educacional, ensinar implica sistematizar ações, planejar estratégias, definir procedimentos e avaliar resultados compondo assim a política de 
ensino. Sborgia (2012) afirma que "o ensino traduz atividade-meio para se levar a efeito um determinado processo educacional".

A reflexão e análise estarão sempre no arcabouço das políticas de ensino, em busca de alcançar horizontes que indicam a promoção do ensino que atenda às demandas da sociedade atual, considerando os avanços da ciência e dos processos de ensino-aprendizagem, com base na relação teoria-prática e na articulação das áreas do saber. As políticas de ensino caracterizam a identidade das instituições educacionais, independentemente do seu nível de atuação.

A instituição escolar necessita oferecer aos agentes envolvidos no processo de ensino às condições necessárias para seu desenvolvimento, emergindo a gestão como mecanismo de articulação entre o ensino e suas possibilidades de desenvolvê-lo. Para Lück (2008):

Gestão educacional corresponde ao processo de gerir a dinâmica do sistema de ensino com um todo e de coordenação das escolas em específico, afinado com as diretrizes e políticas educacionais públicas, para a implementação das políticas educacionais e projetos pedagógicos das escolas compromissados com os princípios da democracia e com métodos que organizem e criem condições para um ambiente educacional autônomo (...) ( LÜCK, 2008, p. 35).

Para Sborgia (2012), gestão é uma forma de administrar que prima pela eficiência e eficácia, podendo assumir novas atribuições, competências, responsabilidades e novos modelos.

Atualmente, nas discussões sobre gestão educacional no cenário nacional, dentro do novo modelo de gestão gerencial, observa-se muito o uso da expressão gestão democrática e participativa. Segundo Veiga (2001), gestão democrática implica em primeiro lugar pensar a estrutura de poder da escola. Distribuir e socializar o poder propicia à prática da participação coletiva na gestão institucional. Com o compartilhamento do poder, as tomadas de decisão irão influenciar no cotidiano da escola e assim, é

[...] necessário que os gestores assumam os rumos da democracia e ponham em prática os mecanismos democráticos que facilitem a construção da autonomia no interior da escola, porque a participação tutelada, sob a direção do Estado, não condiz com a democracia. O gerencialismo se utiliza dos conselhos de controle social, da gestão participativa e da descentralização, como estratégia, para possibilitar o aumento da capacidade de pais e alunos de intervirem nas políticas internas da escola, reduzindo a interferência de professores e burocratas de suas práticas corporativas, permitindo que a 
comunidade escolar se responsabilize pelos resultados alcançados (ARAÚJO E CASTRO, 2011, p.94).

A gestão participativa também visa à construção coletiva de projetos a serem desenvolvidos na escola e pela escola, quando há um envolvimento coletivo em torno de um objetivo comum. Neste caso, ela fortalece os vínculos e há um engajamento mútuo para realizar as ações, de maneira que o ambiente escolar é fortalecido, influenciando positivamente as práticas de ensino. O ensino não ocorre só ambiente de sala de aula e nem pela instrumentalização de um único indivíduo. Antes, ocorre pela troca e compartilhamento de experiências, sendo assim o envolvimento da gestão é preponderante para seu êxito.

Paro (1997) defende uma visão mais crítica da administração escolar, sendo necessário um conhecimento da estrutura socioeconômica da sociedade capitalista em que vivemos, para que a gestão escolar se comprometa com a transformação social. Nesse interim, a figura do gestor é de fundamental importância, pois necessita que não só conheça as bases da função, bem a dimensão do conjunto organizacional e ser capaz de ajustar a realidade escolar em consonância com tudo aquilo que está à sua volta.

\subsection{ASPECTOS CENTRAIS}

\subsubsection{Modelo de Gestão dos IFs}

Com a criação dos IFs, a Lei no 11.892 de 2008 determinou também um modelo específico de gestão que em muito se assemelha ao modelo administrativo das universidades brasileiras. Tal semelhança se faz mais visível na estrutura administrativa central e principal. De acordo com o artigo 11 da referida lei "Os Institutos Federais terão como órgão executivo a reitoria, composta por 1 (um) Reitor e 5 (cinco) Pró-Reitores" (BRASIL, 2008, art.11).

Claramente, o modelo de gestão dos IFs definido por esta legislação é uma cópia da estrutura organizacional das universidades públicas, tendo uma figura central, que é o Reitor, ligado a um conselho, e em uma escala inferior tem-se os cinco 
pró-reitores (Ensino, Extensão, Pesquisa, Administração, Institucional), seguidos dos diretores de faculdade ou no caso dos institutos, diretor de campus.

É interessante observar, que em ambos os modelos de gestão o órgão máximo das instituições é o conselho ou colegiado, especificamente os institutos possuem dois órgãos colegiados:

Art. 10. A administração dos Institutos Federais terá como órgãos superiores o Colégio de Dirigentes e o Conselho Superior.

$\S 1$ 을 As presidências do Colégio de Dirigentes e do Conselho Superior serão exercidas pelo Reitor do Instituto Federal.

$\S 2$ ㅇ O Colégio de Dirigentes, de caráter consultivo, será composto pelo Reitor, pelos Pró-Reitores e pelo Diretor-Geral de cada um dos campi que integram o Instituto Federal.

§ 3o O Conselho Superior, de caráter consultivo e deliberativo, será composto por representantes dos docentes, dos estudantes, dos servidores técnicoadministrativos, dos egressos da instituição, da sociedade civil, do Ministério da Educação e do Colégio de Dirigentes do Instituto Federal, assegurandose a representação paritária dos segmentos que compõem a comunidade acadêmica (BRASIL, 2009).

Os colegiados representam o órgão superior da gestão, com poder máximo de decisão sobre os assuntos relacionados ao ensino, pesquisa, extensão, questões administrativas e financeiras. Como é um órgão representativo de vários segmentos da instituição e atende ao que é definido pela LDB no artigo $3^{\circ}$, que estabelece a gestão democrática do ensino público, como princípio. Conceitualmente, podemos entender a gestão democrática

[...] como processo de aprendizado e de luta política que não se circunscreve aos limites da prática educativa, mas vislumbra, nas especificidades dessa prática social e de sua relativa autonomia, a possibilidade de criação de canais de efetiva participação e de aprendizado do 'jogo' democrático e, consequentemente, do repensar das estruturas de poder autoritário que permeiam as relações sociais e, no seio dessas, as práticas educativas (DOURADO, 2000, p.79).

Outra evidência do princípio democrático da gestão das universidade e Institutos Federais é o processo de escolha dos representantes, por meio de eleição, que escolhe desde o reitor aos diretores de campus e ainda, a presença de órgãos colegiados, com eleições para escolha de representantes dos vários segmentos institucionais. Tais órgãos têm caráter consultivo e deliberativo.

$\mathrm{Na}$ escala hierárquica, em um segundo escalão tem-se a distribuição das pró-reitorias, para desenvolver ensino, pesquisa e extensão em múltiplas áreas de 
conhecimento e nos diversos campos das atividades humanas. Quanto aos IFs, que são instituições de educação superior, básica e profissional, pluricurriculares e multicampi, especializados na oferta de educação profissional e tecnológica nas diferentes modalidades de ensino, com base na conjugação de conhecimentos técnicos e tecnológicos com as suas práticas pedagógicas. (BRASIL, 2008). Pela Lei nº 11.892 de 2008, estão aptos a aturem também nas três dimensões universitárias, que são a pesquisa, o ensino e a extensão. Neste sentido, este modo de administrar os Institutos Federais torna-se algo desafiador, por ser uma instituição sem tradição nessas dimensões e por incorporarem-nas repentinamente. Segundo Otranto (2010), as universidades que já possuem muitos e muitos anos de pesquisa e extensão e se dedicam, em sua maior parte, exclusivamente ao ensino superior, e são por isso mesmo objetos de análises, comparações e discussões sobre a capacidade de lidar com a indissociabilidade do ensino, pesquisa e extensão, princípio que orienta o fazer universitário, autônomo, competente e ético (Moita e Andrade, 2009). Para os IFs, criados recentemente, a coordenação de tais práticas sem falhas se torna quase impossível.

Pelo preceito legal, tanto as universidades, como os IFs gozam de autonomia didático-cientifica, administrativa e patrimonial. Porém, nas universidades públicas, a gestão é marcada por controle orçamentário centralizado e pelo alto grau de formalização das decisões superiores representadas através de leis, decretos e portarias. Em relação aos IFs, a autonomia, além de ser ratificada pela Lei n 11.892 de 2008, já era um atributo garantido à Educação Básica pela LDB, conforme se observa abaixo.

\footnotetext{
Art. $15^{\circ}$ Os sistemas de ensino assegurarão às unidades escolares públicas de educação básica que os integram progressivos graus de autonomia pedagógica e administrativa e de gestão financeira, observadas as normas gerais de direito financeiro público (BRASIL,1996, art. 15ํ).
}

Segundo o que fala a LDB, a autonomia escolar está dividida em: pedagógica, administrativa e financeira. Pedagógica, quando há descentralização de decisões, liberdade na seleção dos conteúdos e métodos de ensino. Quanto à questão administrativa, lida com as relações humanas de todo corpo coletivo orientando-Ihes 
e mostrando caminhos para soluções de problemas. No aspecto da autonomia financeira, trata-se de utilizar os recursos correlatamente aos propósitos educacionais.

Além da autonomia e do princípio democrático de gestão, as IES e IFs ainda têm que lidar com outros desafios como, por exemplo, avaliação externa e interna ou auto avaliação, estabelecida pela Lei $n^{\circ} 10.861$ de 2004, que criou 0 Sistema Nacional de Avaliação da Educação Superior (Sinaes). O novo sistema, que instituiu de forma integrada a avaliação das instituições, dos cursos e do desempenho dos estudantes, estabeleceu igualmente que a avaliação das instituições considerará necessariamente as dez dimensões definidas em lei e que terá dois momentos: a auto avaliação, a ser coordenada por Comissões Próprias de Avaliação (CPAs) e a avaliação externa, a ser realizada por comissões de docentes atuantes na educação superior, devidamente cadastrados e capacitados.

Quanto à avaliação das IES, se incluem os IFs por também atuarem no ensino superior. Segundo Stallivieri (2006), a avaliação institucional tem um caráter sistêmico, integrando os espaços, os momentos e os diferentes instrumentos de avaliação, com intuito de ter assegurando uma melhor integração da avaliação com as políticas públicas de Estado, fazendo o uso adequado dos resultados em busca de desempenho satisfatório do ensino superior brasileiro.

Enfim, como o modelo de gestão dos IFs, têm muitas similaridades em relação ao das universidades, cabe um aprofundamento maior, para identificar em que ponto eles são de fato são semelhantes. 


\section{METODOLOGIA DA PESQUISA}

\subsection{MODALIDADE DA PESQUISA}

A pesquisa desenvolvida, cujo tema é "O modelo de gestão aplicado ao ensino no IFPI frente às configurações dos IFs". Devido a pesquisa ser de caráter mais abrangente, optou-se pela pesquisa qualitativa. Uma das suas especificidades, destaca-se, que a pesquisa qualitativa não requer métodos e técnicas estatísticas, esclarece Silva (2001). "O ambiente natural é fonte direta para a coleta de dados e o pesquisador é o instrumento chave" (SILVA, 2001, p.20). As caraterísticas da pesquisa qualitativa, na percepção de Silva (2001), assemelham-se muito com as características básicas apontadas por Godoy (1995, p.62), a saber: "o ambiente natural como fonte direta dos dados e o pesquisador como instrumento fundamental", caráter descritivo da pesquisa, valorização pelo investigador do significado que as pessoas dão às coisas e à sua vida e o enfoque indutivo na análise dos dados.

A pesquisa qualitativa é alvo de muitas críticas, principalmente da corrente positivista, a qual atribui a incapacidade de prever e determinar a ação humana. É um "trabalho intersubjetivo, intensa e livremente comunicado, no qual os pesquisadores se controlam mutuamente, dentro de parâmetros naturalmente discutíveis" (DEMO, 2002, p.365).

Na literatura estudada, Demo (2002), Minayo (2001), Kerlinger (1980), não mencionam a pesquisa qualitativa de forma isolada. A caracterização da pesquisa qualitativa, na grande maioria dos textos, surge como um contraponto à pesquisa quantitativa, ou ainda tentando justificar que aquele tipo de investigação também pode fornecer resultados seguros.

Para Demo (2002), a pesquisa qualitativa se ocupa dos detalhes, os quais se traduzem por precisão, conforme se observa no excerto abaixo:

Mais que em qualquer outro paradigma, a pesquisa qualitativa se põe 0 desafio de captar com a maior precisão possível o impreciso. Há aí clara dissonância entre epistemologia e ontologia, mas pode ser relativamente contornada pela via da formalização flexível, discutível. Discutível" não significa aqui somente "frágil", mas sobretudo critério de demarcação científica (DEMO, 2002, p.365). 
Para Minayo (2001), é falsa a ideia de a pesquisa quantitativa seria um tipo de estudo pautado pela objetividade em oposição à subjetividade presente nos estudos qualitativos. A diferenciação constitui-se, antes, em natureza e profundidade, o que vem a corroborar com a visão explicitada por Demo (2002), apresentada logo acima. Neste sentido:

Não existe um "continuum" entre "qualitativo-quantitativo", em que o primeiro termo seria o lugar da "intuição", da "exploração" e do "subjetivismo"; e o segundo representaria o espaço do científico, porque traduzido "objetivamente" e em "dados matemáticos".

A diferença entre qualitativo-quantitativo é de natureza. Enquanto cientistas sociais que trabalham com estatística apreendem dos fenômenos apenas a região "visível, ecológica, morfológica e concreta", a abordagem qualitativa aprofunda-se no mundo dos significados das ações e relações humanas, um lado não perceptível e não captável em equações, médias e estatísticas (MINAYO, 2001, p.22).

Não se pode desconsiderar, porém, que a pesquisa qualitativa é objeto de inúmeras críticas a ela direcionadas, sob a acusação de falta de rigor e cientificidade. Desse modo:

Muitos cientistas sociais acusam a pesquisa qualitativa de não apresentar padrões de objetividade, rigor e controle científico, já que não possui testes adequados de validade e fidedignidade, assim como não produz generalizações que visem à construção de um conjunto de leis do comportamento humano (KERLINGER ,1980, p. 36).

Divergências e críticas à parte, afirmamos que a pesquisa qualitativa constitui-se em um percurso confiável de investigação e exploração de uma realidade social.

Por todas as características, a pesquisa qualitativa é a que melhor atende a proposta de investigação, visto que o problema a ser trabalhado está no cerne da especificidade da pesquisa qualitativa. 


\subsection{O QUE DIZEM OUTRAS PESQUISAS SOBRE MODELOS DE GESTÃO DO ENSINO}

$\mathrm{Na}$ tentativa de trazer a discussão atual sobre o modelo de gestão aplicado ao ensino, buscou-se observar a estrutura organizacional, os princípios teóricos e as características da gestão de ensino no processo educacional, em textos que faziam abordagens sobre gestão educacional.

Realizou-se uma pesquisa on-line em inúmeras bases de dados de periódicos, repositórios de dissertações e teses de várias universidades utilizando-se as palavras chaves, "gestão do ensino", "gestão aplicada ao ensino", "Direção de Ensino". Não foram encontradas muitas referências em relação à temática específica da gestão de ensino. Verificou-se a existência de inúmeros textos científicos, mas com os temas de gestão escolar ou gestão educacional. Assim, depois de selecionar alguns textos, fez-se uma triagem para estudar aqueles que tivesse mais relação com a gestão de ensino, em detrimento dos textos com abordagens de gestão no aspecto administrativo. Restaram cinco textos para análise e desses apenas um, especificamente, traz a discussão da gestão de ensino. Destaca-se ainda, que a terminologia utilizada - gestão de ensino - é de um texto que faz referência a um Instituto Federal, onde a expressão é muito utilizada.

Pela análise dos textos, em um primeiro momento, ficou evidente que os IFs não só se constituem como uma instituição sui generis no tocante à composição, às características, os objetivos, mas também, no que diz respeito ao modelo de gestão implantado.

O modelo de gestão dos IFs tem uma influência marcante do modelo universitário, com a divisão em pró-reitorias de ensino, pesquisa e extensão e tendo a figura do Reitor com gestor superior. Mas os IFs imprimiram um modelo de gestão ainda mais especifico, pois nos campi, a estrutura da rede, se repete, só que em diretorias e coordenações. A gestão de cada campus de um IF é composta da direção geral, de cunho mais administrativo, e que delibera e controla todas as ações, mas sem imersão especifica no ensino, a Direção de Ensino, voltada para as questões do processo ensino-aprendizagem e ainda o departamento de administração que gerencia a equipe técnica que fornece o suporte ao ensino, além de várias 
coordenações ligadas à direção geral, ou de ensino, ou do departamento de administração.

Para direcionar o estudo dos textos, foram analisados os seguintes pontos: terminologia empregada para gestão da área educacional e suas características. Assim, é possível visualizar as diferenciações dos aspectos de gestão em cada contexto educacional. Os textos estudados foram: Instituições de Ensino: Implantação de um Modelo de Gestão baseado em diretrizes (LEITE, 2010); Novo design para a Rede Federal de Educação Tecnológica (FERNANDES, 2008); a dissertação sobre o estudo da Gestão Democrática da Escola Agrotécnica Federal (SÁ, 2009); Gestão de Ensino, Direção de Ensino - Iffarroupilha Câmpus Santa Rosa (SOBRINHO, 2014) e, Gestão da escola, qualidade do ensino e avaliação externa: desafios na e da escola (GARCIA, 2010).

\subsubsection{Gestão da área educacional - terminologia empregada}

O artigo "Implantação de um Modelo de Gestão baseado em diretrizes", de autoria de Leite (2010), traz a discussão sobre os desafios das instituições de ensino no tocante à gestão educacional e apresenta uma proposta de gestão baseada em diretrizes.

O termo empregado para definir o trabalho de gerenciar as atividades de uma instituição escolar foi gestão educacional, que no texto analisado vem com ênfase na organização das funções e das pessoas, enfatizado o caráter administrativo, para maximizar resultados. Defende um modelo de gestão voltado para as instituições de ensino que direcione a uma gestão estratégica.

\footnotetext{
O grande desafio das instituições de ensino tem sido melhorar a sua performance e desempenho na gestão, tanto na administração dos recursos disponíveis, na melhoria de seus indicadores e no quadro de profissionais contratados. Este desafio tem se traduzido na busca de um modelo que consiga transformar a instituição numa referência administrativa e educacional, apoiada em indicadores que consigam expressar a padronização dos processos internos (LEITE, 2010, p. 02).
}

Foi estudada uma dissertação que enfatiza a gestão democrática de escola Agrotécnica Federal (Sá, 2009), onde foi analisado o modelo de gestão entre 2002 a 
2006. O autor faz referência à gestão da escola, enfatiza as especificidades da gestão, como autonomia e caráter democrático e retrata aspectos burocráticos e rotineiros. “Conceitos de descentralização e autonomia não são sinônimo de democratização ou garantia de participação. Os aspectos administrativos e burocráticos também podem prevalecer sobre os aspectos pedagógicos" (SÁ, 2009, p. 104).

No texto: Novo design para a Rede Federal de Educação Tecnológica, Fernandes (2008) traz análise do novo modelo da rede federal, destaca a estrutura administrativa e enfatiza uma das características dos IFs, que é de considerar os arranjos produtivos locais no momento de definir oferta dos cursos.

O termo utilizado foi gestão de ensino e está voltado para as questões relacionadas ao processo de ensino-aprendizagem e também aspectos administrativos. Enfoca a gestão com caráter mais institucional, e para isso usa o termo gestão institucional. "Objetiva para a organicidade dessas instituições, objetivando minimizar as dificuldades ou garantir a eficácia da gestão" (FERNANDES, 2008, p.10).

No artigo Gestão de Ensino, Direção de Ensino - IF Farroupilha Câmpus Santa Rosa, Sobrinho (2014), faz-se referência a um estudo sobre a Direção de Ensino de um campus do IF Farroupilha, onde o autor relata sua experiência como diretor de Ensino e enfoca as especificidades da gestão no contexto dos IFs.

[...] gestão de ensino do câmpus é o atendimento qualificado ao educando proporcionando todas as ações necessárias para concretização dos projetos pedagógicos dos cursos e a formação integral dos educandos através da integração entre a formação básica e a formação específica. Por esse motivo o planejamento, implementação, acompanhamento, avaliação.(SOBRINHO, 2014, p. 15)

Gestão de ensino é o termo utilizado para referir especificamente ao trabalho pedagógico, visto que os aspectos administrativos são de responsabilidade dos diretores administrativo e geral, aspecto comum aos IFs.

No texto: Gestão da escola, qualidade do ensino e avaliação externa: desafios na e da escola, Garcia (2010) retrata a política de avaliação externa e sua repercussão na qualidade do ensino, com base no trabalho de organização da gestão escolar. Gestão da escola é a nomenclatura usada, tendo a função de: 
mencionado anteriormente, optamos por não diferenciar os termos gestão e administração e utilizamos a expressão enquanto meio para viabilizar a organização da escola para o alcance de objetivos e metas definidos pela instituição (GARCIA, 2010, p. 62).

\subsubsection{Gestão da área educacional - características}

Leite (2010) defende o modelo de gestão estratégica baseado em diretrizes organizacionais e equipes auto gerenciais, fundamentado em dois pontos: gestão de equipe e gestão de diretrizes.

São as pessoas integrantes das equipes de trabalho, as responsáveis pelas mudanças através de diagnóstico interno, implantação e gestão das diretrizes para melhorias organizacionais, e somente sua cooperação e empreendedorismo, pode de fato lograr os resultados desejados (LEITE, 2010, p.9).

O autor Sá (2009), destaca a gestão democrática como referência para a gestão educacional e ressalta como características a participação da comunidade interna e externa no processo de escolha, os mecanismos de escola dos dirigentes, descentralização das decisões, autonomia da escola, implantação e funcionamento de colegiados.

Fernandes (2008) enfatiza que a gestão de ensino está baseada nos princípios da gestão democrática e participativa, sendo suas características a participação ativa dos membros da equipe de gestão nas tomadas de decisões, comunicação aberta para alinhamento das ações, transparência nas informações institucionais, utilização da preocupação com a qualidade.

Para Sobrinho (2014), a gestão de ensino é retratada como uma atividade meio que se articula com a atividade fim que é o ensino e cabe à gestão de ensino garantir espaços abertos, onde os atores possam trabalhar buscando despertar a criatividade e inovação. A gestão de ensino também está baseada no princípio de gestão democrática.

Para Leite (2010), a gestão democrática e autônoma é o modelo defendido pela autora. Como a gestão democrática é voltada para educação pública, a autora defende que a característica democrática é mais do que participação e sim o poder de decisão que o público passa a adquirir. 
Pelos textos analisados percebe-se que a terminologia empregada para gestão na área educacional vária muito de instituição para instituição e mais que uma questão de denominações diferentes, tem-se concepções diferentes, pois em algumas instituições escolares, gestão de ensino não existe separada da gestão administrativa, e que acaba sendo privilegiada em detrimento das questões do ensino, esse por sua vez, fica relegado aos aspectos burocráticos, como por exemplo cumprimento de carga-horária, preenchimento de diários, são algumas das cobranças clássicas da gestão de ensino de uma instituição escola.

Quanto as características, em todos os artigos há uma relação com os princípios de democracia e autonomia, considerando-os como pontos fundamentais para o êxito da gestão e com base nestes princípios são estabelecidas as relações de trabalho, buscando harmonizar os aspectos administrativos e pedagógicos. Enfim, o termo gestão de ensino é novo, restrito ao IFs, porém com a proposta única de lidar exclusivamente com o ensino.

\subsection{IDENTIFICAÇÃO DO CAMPO DA PESQUISA E SEUS SUJEITOS - AMOSTRA.}

A pesquisa de campo ocorreu no Instituto Federal de Educação, Ciências e Tecnologia do Piauí (IFPI) - Campus Corrente e na Reitoria do IFPI, localizada na cidade de Teresina - PI.

O Instituto Federal de Educação, Ciências e Tecnologia do Piauí (IFPI) Campus Corrente está localizado no município de Corrente no extremo sul do Piauí, no território Chapada das Mangabeiras e conta com uma população de 25.407 habitantes (2010), dados do IBGE (Instituto de Geografia e Estatística). Tem como principal atividade econômica a criação de gado e agricultura. O município de Corrente que fica a $940 \mathrm{Km}$ da capital Teresina é bastante isolado dos grandes centros urbanos. Em 29 de janeiro de 2010, por meio da Portaria no 125, o IFPI (na época CEFET) Campus Corrente foi oficialmente autorizado a funcionar e começou ofertando cursos técnicos de Agronegócio e Informática integrados ao ensino médio, também na modalidade concomitante/ subsequente e ainda o curso superior de Licenciatura em Matemática. 
Ao longo de cinco anos de funcionamento, o Campus Corrente conta, além dos cursos ofertados no início, com mais os cursos técnicos de Administração e Agronomia, o primeiro integrado ao ensino médio e também concomitante/subsequente e o último na forma concomitante e subsequente, e o curso Tecnólogo em Gestão Ambiental. A estrutura administrativa é composta pela Diretoria Geral, a Diretoria de Ensino, Chefia de Departamento Administrativo, com subdivisões hierárquicas e, ainda, Coordenações de Extensão e Pesquisa. Conta também com 38 técnicos administrativos e 48 docentes, sendo 2 temporários e os demais efetivos.

A Direção de Ensino do IFPI (DIREN) - Campus Corrente, constituiu-se também no nosso campo de pesquisa. Tendo por base a Resolução n²0/2011 do Conselho Superior (CONSUP), no Art. 548: A Diretoria de Ensino é a unidade organizacional responsável por planejar, desenvolver, orientar e monitorar as atividades de ensino para o Campus.

A Pró-Reitoria de Ensino (PROEN) do IFPI foi outro local onde a pesquisa foi realizada. A PROEN faz parte da estrutura administrativa do IFPI, que compõe a Reitoria, inclusive ocupando o mesmo espaço físico, localizado na cidade Teresina, que é a capital do Piauí, que conta com uma população de 767.559 habitantes, segundo o IBGE (2010). Está situada no Centro-Norte Piauiense, sendo, a única capital da Região Nordeste que não é banhada pelo Oceano Atlântico.

Com base no artigo 22 da Resolução n01, de 31 de agosto de 2009, a Pró-Reitoria de Ensino tem como atribuições planejar, superintender, coordenar, fomentar e acompanhar as políticas de ensino, articuladas à pesquisa e à extensão.

Delimitado o campo da pesquisa, na sequência buscou-se selecionar a amostra, ou seja, definir quem e quantos sujeitos poderiam participar da investigação. Segundo Gil (2014), na pesquisa social, a amostragem é dividida em dois grupos: amostragem probabilística e não probabilística. Na pesquisa em questão, optou-se pela amostragem não probabilística por tipicidade ou intencional que,

[...] consiste em selecionar um subgrupo da população que, com base nas informações disponíveis, possa ser considerado representativo de toda população. A principal vantagem da amostra por tipicidade está nos baixos custos de sua seleção. Entretanto, requer considerável conhecimento da população e do subgrupo selecionado (GIL, 2014, p.94).

$\mathrm{Na}$ amostragem não probabilística do tipo intencional, fez-se uso do princípio da amostragem representativa que tem como exigência básica o "referencial 
de amostragem que operacionaliza a população. Ele se compõe de uma lista específica de unidades que são levadas em conta na seleção". (BAUER et al., 2015, p.41) e que por sua vez essas unidades têm que apresentar na população e também na amostra, sendo uma representação do todo. No caso da pesquisa em questão para a escolha dos docentes do grupo focal foram consideradas as unidades: atuar em vários níveis de ensino dentro do IFPI e ter dedicação exclusiva. No caso, os coordenadores foram selecionados um de cada nível educacional ofertado pelo IFPICampus Corrente. No caso dos gestores de ensino, não houve seleção de amostra, visto que foram considerados as duas gestoras de ensino, tanto a nível geral - PróReitora, como a nível local - Diretora de Ensino. "A qualidade do referencial de amostragem é medida pelo quanto ela não consegue abranger todos os elementos que devem ser pesquisados" (BAUER et al., 2015, p.41).

...a definição de critérios segundo os quais serão selecionados os sujeitos
que vão compor o universo de investigação é algo primordial, pois interfere
diretamente na qualidade das informações a partir das quais será possível
construir a análise e chegar à compreensão mais ampla do problema
delineado (DUARTE, 2002, p.41).

Seguindo esses princípios metodológicos descritos, os sujeitos foram selecionados. A amostra ficou composta de 8 (oito) professores do IFPI - Campus Corrente, os quais foram selecionados tendo como referencial da amostragem a atuação em todos os níveis de ensino, desde da educação básica ao ensino superior, especificidade que tem relação direta com alguns objetivos da pesquisa; e pelos gestores de ensino - Pró-Reitora e Diretora de Ensino, por serem atores principais da estrutura de gestão do ensino. Ainda contamos com a participação de 3 (três) coordenadores de curso, que incialmente não tinham sido incluídos como sujeitos da pesquisa. No projeto de investigação, estava previsto a participação do Reitor do IFPI e do Diretor Geral do Campus Corrente, mas com o andamento da investigação, percebeu-se que os coordenadores estavam mais ligados diariamente com as especificidades do modelo de gestão do ensino, inclusive por fazerem parte do organograma da DIREN e vivenciarem o processo de ensino de forma endógena, mas do que o Reitor e Diretor Geral do Campus, por esse motivo se deu a substituição. 


\subsection{INSTRUMENTOS DE COLETA DE DADOS}

Para delimitar o modelo, foi considerada a estrutura organizacional, as funções da PROEN e DIREN e as principais ações de fato desenvolvidas em ambas as instâncias da gestão de ensino. A estrutura organizacional, as funções e ações, compreendem, para o estudo proposto à modelagem de gestão do ensino. E com relação a configuração dos IFs foram considerados os objetivos e características dos IFs definidos na Lei no 11.892 de 2008.

Os instrumentos de coleta de dados foram: análise documental, observação não participante, grupo focal, entrevistas semiestruturada e questionários abertos.

Em se tratando de pesquisa, os documentos não têm uma origem específica, podendo ser desde de documentos oficiais até imagens visuais, Bauer (2002). A opção pela análise documental se deu pela necessidade de buscar esclarecimentos sobre como ocorreu o processo de definição do modelo de gestão aplicado ao ensino do IFPI, além de ter uma visão de como é configurada a instituição, do papel dos gestores ligados ao ensino, suas atribuições a estrutura organizacional de que dispõem. Assim, dos documentos analisados do IFPI, que tratam do ensino foram: Organização Didática (OD), Regimento interno (RI) do IFPI - Campus Corrente.

O procedimento para análise foi o de "operação intelectual: o recorte de informação, divisão de categorias segundo critérios de analogia, representação sob forma condensada por indexação" (BARDIN, 2011, p.52).

Outro instrumento utilizado foi a observação não participante, que "é um processo em que o pesquisador deve ser cada vez mais um participante e obter acesso ao campo de atuação e às pessoas" (MARELIM, 2003, p.52) e cujo objetivo final é revelar verdades práticas e teóricas a respeito da cultura dos seres humanos na realidade do dia- a- dia. Uma vantagem que a definiu como instrumento de coleta foi que a observação permite verificar comportamentos, atitudes, opiniões, sentimentos, ou seja, uma visão real no momento que está ocorrendo.

A observação não participante é muito utilizada em pesquisa qualitativa e é uma atividade que permite a análise documental simultânea, aspecto que será usado nessa pesquisa na análise dos resultados. A observação depende muito do 
observador, pois é responsável pelo registro e depende das suas qualidades, tais como, sensibilidade, conhecimento, inteligência e imaginação, Mattos (2001).

Outra opção de coleta de dados adotada foi o grupo focal, que consiste em uma entrevista em grupos, onde os participantes, geralmente de 6 a 8 pessoas, debatem pontos focais de um assunto, sob o comando de um moderador, que controla o tempo e vai introduzindo os novos tópicos do assunto. "A coleta de dados através do grupo focal tem como uma de suas maiores riquezas basear-se na tendência humana de formar opiniões e atitudes na interação com outros indivíduos" (ERVOLINO, 2001, p. 116).

O público alvo do grupo focal, professores do IFPI - Campus Corrente e o critério de seleção dos participantes, atuação em níveis diferenciados de ensino. Uma peculiaridade: embora todos tenham o mesmo ambiente de trabalho, não apresentavam vínculos de amizade. Este esclarecimento se faz necessário, visto que um dos cuidados que o pesquisador necessita ter, é que no momento da seleção, não é recomendável escolher grupos de amigos e nem do mesmo do ambiente de trabalho, mas como no campus Corrente do IFPI tem uma rotatividade muito grande de professor, esse cuidado acaba não enquadrando no contexto. Segundo proposto nesta pesquisa, o grupo focal é um dos instrumentos que irá dialogar com outros instrumentos de pesquisa.

\begin{abstract}
A posição que o grupo focal vai ocupar na investigação varia de acordo com o objetivo do pesquisador: alguns trabalhos usam o grupo focal para ajudar na formulação de questionários para pesquisas quantitativas, outros utilizam em combinação com outros métodos qualitativos, como observação participante ou em entrevistas em profundidade (ERVOLINO, 2001, p. 117).
\end{abstract}

Os últimos instrumentos de coleta utilizado, foram entrevistas semiestruturadas e os questionários abertos. A entrevista é a técnica mais usual na pesquisa qualitativa, consiste em "o investigador se apresentar frente ao investigado e Ihe formular perguntas, com o objetivo de obtenção de dados que interessam a investigação" (GIL, 2014, p.109). Os dados coletados podem ser objetivos ou subjetivos, dependendo do tipo de entrevista.

Existem muitos tipos de entrevistas, classificados em diferentes grupos,

Em geral, as entrevistas podem ser estruturadas e não-estruturadas, correspondendo ao fato de serem mais ou menos dirigidas. Assim, toma-se possível trabalhar com a entrevista aberta ou não-estruturada, onde o 
informante aborda livremente o tema proposto; bem como com as estruturadas que pressupõem perguntas previamente formuladas. Há formas, no entanto, que articulam essas duas modalidades, caracterizando-se como entrevistas semi-estruturadas (MINAYO, 2001, p.55).

A opção, nessa pesquisa, foi a entrevista semiestruturada, pois como o número de entrevistados era relativamente pequeno, permitindo uma imersão maior no contexto do ensino, por meio das questões e assim colher dados suficientes para conclusão da pesquisa.

Dentre as vantagens da técnica de entrevista, destaca-se a que possibilita de coletar dados diversificados, além do procedimento de elaboração das questões ser bem familiar ao universo escolar. Já uma desvantagem pode ser a desmotivação do entrevistado em responder às questões, e ainda "a influência exercida pelo aspecto pessoal do entrevistador sobre o entrevistado" (GIL, 2014, p.110).

\subsection{ANÁLISE E INTERPRETAÇÃO DOS RESULTADOS}

Após coleta de dados e sua tabulação, o passo seguinte é a análise e interpretação dos resultados.

\footnotetext{
Estes dois processos, apesar de conceitualmente distintos, aparecem sempre estreitamente relacionados. A análise tem como objetivo organizar e sumariar dados de forma tal que possibilitem o fornecimento de respostas ao problema proposto para investigação. Já interpretação temo como objetivo a procura do sentido mais amplo das respostas, o que é feito mediante sua ligação a outros conhecimentos anteriormente obtidos (GIL, 2014, p.156).
}

Com os dados brutos, organizamos em grupos de análises, sendo a análise documental e observação não participante um grupo e no outro juntaram-se o grupo focal, as entrevistas e os questionários. Para análise dos dados, mais especificamente para as entrevistas semiestruturadas, questionários abertos e o grupo focal, adotouse o processo de categorização, para a tabulação dos dados e análise, também foi utilizado o software WELF QDA, que é uma ferramenta gratuita, para análise de dados textuais é de fácil utilização, embora seja todo em inglês, mas permite exportar textos em vários formatos digitais, também organizar as categorias em uma estrutura de 
árvore, possui estatísticas de codificação simples e ainda avalia padrões de codificação em vários documentos. Considerando que,

A categorização é uma operação de classificação de elementos constitutivos de um conjunto por diferenciação e, em seguida, por reagrupamento segundo o gênero (analogia), com critérios previamente definidos. O critério de categorização pode ser semântico (Categorias temáticas: por exemplo, todos os temas que significam ansiedade ficam agrupados na categoria "ansiedade", enquanto que os que significam descontração ficam agrupados sob o título conceitual "descontração) (BARDIN, 2011, p.147).

E também é um processo que isola os elementos criando um inventário, na primeira etapa e a segunda é a classificação, ou seja, dividir os elementos.

Para análise documental e observação não participante, foram estabelecidos indexadores, os quais são uma espécie de palavras-chaves, como se fosse um índice e assim buscar pontos de intercessão

Como a pesquisa foi realizada em dois contextos diferentes: um local IFPI, na DIREN do Campus Corrente, e no contexto macro da gestão de ensino do IFPI, na PROEN em Teresina, os dados foram analisados seguindo as mesmas categorias para identificar a influência da gestão de ensino geral no contexto específico.

Os resultados foram expostos de forma descritiva e também por meio de quadros, de modo a facilitar a compreensão dos resultados alcançados. 


\section{ETAPA DAS ANÁLISES}

Para a análise e discussão, os dados foram organizados em blocos, em que se destacam as perspectivas do ponto vista legal, do pondo de vista da gestão de ensino e do ponto de vista dos docentes, com o interesse de buscar respostas para o problema de pesquisa, o qual consiste em saber se o modelo de gestão aplicado ao ensino no IFPI contempla com êxito as finalidades e características dos IFs.

$\mathrm{Na}$ primeira perspectiva, buscou-se analisar os documentos institucionais Regimento Interno (RI), Organização Didática (OD), considerando os aspectos relacionados ao modelo de gestão, no que diz respeito à estrutura organizacional e as especificidades das funções desenvolvidas pela PROEN e DIREN. Ainda complementando essa primeira etapa, as informações coletadas na análise documental, somam-se às informações da observação não participante. Na segunda etapa, tem-se a análise das entrevistas com a Pró-Reitora de Ensino, lotada em Teresina, e a Diretora de Ensino, lotada no Campus Corrente, os questionários com três coordenadores e os dados obtidos mediante o grupo focal

$\mathrm{Na}$ fase da pesquisa que consiste na discussão dos dados coletados, na análise documental, onde foram focalizadas a estrutura organizacional e as funções da PROEN (Pró - Reitoria de Ensino) e DIREN (Direção de Ensino), nos vários documentos institucionais, RI (Regimento Interno), OD (Organização Didática), utilizou-se o procedimento de operação intelectual, defendido Bardin (2011), "são divisões por categorias tendo como critério a analogias, representada sobe forma condensada por indexação", (BARDIN, 2011, p.52). São estabelecidas as categorias mais abrangentes e ao extrair as explicações ou o conteúdo de cada categoria são definidas palavras-chaves que se liga a outra categoria.

\subsection{ANÁLISE DOCUMENTAL E OBSERVAÇÃO NÃO PARTICIPANTE}

Os dados obtidos por meio da análise documental vêm acompanhados daqueles produzidos por meio da observação não participante, realizada na PROEN, num total de $48 \mathrm{~h}$, divididas em duas semanas, sendo na primeira semana $8 \mathrm{~h}$ e na 
segunda 40h. Foi definido um roteiro, na intenção de vivenciar o dia-a-dia da gestão e assim perceber se a prática traduz literalmente o que definem os documentos institucionais.

Os documentos institucionais Regimento Interno, Organização Didática, são regulamentos, resoluções, normatizações que direcionam todas as ações do IFPI, bem como, estabelecem a forma de organização do trabalho na Reitoria e nos Campi. Cabe detalhar.

\footnotetext{
O Regimento Interno Geral do Instituto Federal do Piauí (IFPI) é um manual que descreve, de forma estruturada e sistemática, as descrições sumárias e as competências das unidades organizacionais pertencentes à estrutura organizacional, conforme estrutura organizacional aprovada pela Resolução no 019/CONSUP e Portaria da Reitoria № 1203, de 24/11/2011, publicadas no Boletim de Serviço Edição Extra no 04, de 24/11/2011. (Regimento Interno -IFPI, 2011, p.04)
}

De CEFET (Centro de Federal de Educação Tecnológica) a IFPI, pela Lei no 11.892 de 2008, foi um processo de transformação brusca pela quantidade de mudanças, a criação de uma nova instituição, com novo perfil, nova forma de administrar, nova identidade. Assim, foi necessário mudar também as normas, regulamentos internos e adaptar-se às mudanças, sendo que o Regimento Interno foi um dos documentos institucionais que sofreu alterações, uma vez que, era nova estrutura administrativa com novos cargos, funções e atribuições.

Para análise documental no Regimento Interno e na Organização Didática foram definidas algumas categorias. O Regimento Interno, mais detidamente a Subseção III, trata da PROEN (Pró-Reitoria de Ensino) - unidade gestora que responde pelo ensino em todos os Campi, possui uma ligação vertical com as DIREN - Direções de Ensino - unidade específica de cada Campus. Por meio do procedimento de operação intelectual, que consiste na seleção das categorias, aqui definidas, conforme o Quadro 2.

O Regimento Interno (RI) define que a PROEN é uma unidade organizacional, subordinada à Reitoria, que planeja, organiza, gerencia e avalia todas as políticas e diretrizes do processo de ensino. Subdividida em 01 (uma) assessoria pedagógica e educação especial, 01 (uma) diretoria, 03 (três) departamentos e 04 (quatro) coordenações. Pela normativa legal a PROEN é responsável pela condução geral, ou seja, nos 20 Campi do IFPI, de todas as ações relacionadas ao ensino. A princípio parece ser a solução ideal, contar com uma unidade para conduzir o 
processo de ensino. Porém, o ensino não é a uma atividade-meio, é uma atividadefim, que depende dos atores, acompanhando de perto para haver uma efetividade do processo ensino-aprendizagem. Paro (2002) esclarece que as atividade-fim,

[...] referem-se a tudo o que diz respeito à apropriação do saber pelos educandos. Nelas inclui-se a atividade ensino-aprendizagem propriamente dita, desenvolvida dentro e fora da sala de aula; mas não é impróprio incluírem-se também os serviços de coordenação pedagógica e de orientação educação, na medida em que estes também lidam diretamente com questões pedagógicas (Paro, 2002b, p. 75).

Quadro 2 - Categorias de Análise I

\begin{tabular}{|c|c|c|c|}
\hline RI (2011) & Categorias & Indexadores & Disposição Legal \\
\hline \multirow{6}{*}{ 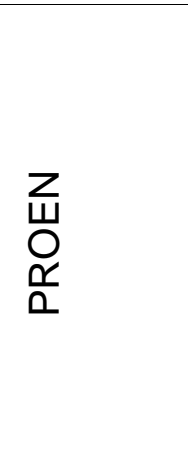 } & 1 - Definição; & Unidade & Art. 74 \\
\hline & 2 - Composição; & Subdivisão & Art. 74 \\
\hline & \multirow{4}{*}{3 - Competência; } & \multirow{4}{*}{$\begin{array}{l}\text { Planejamento, organização, } \\
\text { estabelecimento, } \\
\text { monitoramento; avaliação }\end{array}$} & Parágrafo único \\
\hline & & & Art. 74 \\
\hline & & & Parágrafo único \\
\hline & & & $\begin{array}{l}\text { Incisos: I, II, III } \\
\text { IV.V.VI,VII,VIII, IX. }\end{array}$ \\
\hline
\end{tabular}

Fonte: Elabora pela autora, 2015.

Partindo destas constatações legais e cientificas, é preciso observar se a estrutura organizacional, que a PROEN dispõe é suficiente para atender o ensino em todas as especificidades, mesmo considerando a pluralidade de oferta em vários níveis e modalidades.

Na observação não participante realizada na PROEN, o primeiro item do roteiro consistia em observar a organização da estrutura da PROEN, na prática.

No espaço físico destinado à PROEN encontram-se nove servidores sendo: a Pró-reitora, quatro departamentos, uma coordenação e um procurador institucional, uma assessora técnica e atendente. Foi verificado que a estrutura organizacional não era a mesma definida no Regimento Interno, havia tido alterações e um dos membros presentes informou que era uma nova configuração administrativa, definida pela Resolução 11/2014 do Conselho Superior (CONSUP), onde ficou estabelecido cinco departamentos, nove coordenações, uma procuradoria institucional, uma assessoria e um atendente, onde a maioria tem gratificações, como 
indicam as siglas CD (Cargo de Direção) e FG (Função Gratificada), conforme Quadro 3. Curiosamente nem todas as coordenações ficam no mesmo espaço físico, algumas tem seus espaços em outros prédios, como a coordenação da EAD (Educação à Distância), por ser mais estratégico para suas atividades. Mas os coordenadores têm trânsito livre na Pró-Reitoria e se reúnem esporadicamente com a Pró-Reitora ou quando tem demanda.

Quadro 3 - Estrutura organizacional da PROEN (IFPI)

\begin{tabular}{lccc}
\hline \multicolumn{1}{c}{$\begin{array}{c}\text { UNIDADE } \\
\text { ORGANIZACIONAL }\end{array}$} & $\begin{array}{c}\text { CARGO/ } \\
\text { FUNÇÃO }\end{array}$ & QUANT. & $\begin{array}{c}\text { CD/ } \\
\text { FG }\end{array}$ \\
\hline $\begin{array}{l}\text { 3.1.13 - Pró-Reitoria de } \\
\text { Ensino - PROEN }\end{array}$ & Pró-reitor & 01 & CD-2 \\
& Assessor da Pró-reitoria & 01 & - \\
\hline $\begin{array}{l}\text { A.1.13.1 - Departamento } \\
\text { Pedagógico }\end{array}$ & Chefe de Departamento & 01 & CD-4 \\
\hline $\begin{array}{l}\text { 3.1.13.2 - Departamento de } \\
\text { Ensino Superior }\end{array}$ & Chefe de Departamento & 01 & CD-4 \\
$\begin{array}{l}\text { 3.1.13.2.1 - Coordenação de } \\
\text { Ensino de Licenciaturas }\end{array}$ & Coordenação & 01 & - \\
$\begin{array}{l}\text { 3.1.13.3.2 - Coordenação de } \\
\text { Tecnologias }\end{array}$ & Coordenação & 01 & - \\
$\begin{array}{l}\text { 3.1.13.3.3 - Coordenação de } \\
\text { Registro e Diplomação }\end{array}$ & Coordenação & 01 & FG-2 \\
$\begin{array}{l}\text { 3.1.13.3.4 - Coordenação de } \\
\text { Redes da Biblioteca }\end{array}$ & Coordenação & 01 & - \\
\hline $\begin{array}{l}\text { 3.1.13.2.4 - Departamento } \\
\text { de Ensino Técnico }\end{array}$ & Chefe de Departamento & 01 & CD-4 \\
$\begin{array}{l}\text { 3.1.13.2.4.1 - Coordenação } \\
\text { de Ensino Técnico }\end{array}$ & Coordenação & 01 & - \\
\hline
\end{tabular}

3.1.13.2.5 - Departamento

Chefe de Departamento

01 de Projetos e Programas

Especiais 
3.1.13.2.5.2 PARFOR

3.1.13.2.5.3 PRODOCÊNCIA

3.1.13.2.6 Procurador Institucional

3.1.13.2.6.1 Coordenação de Estatística Institucional
Coordenador

01

Bolsa

Coordenador

Procurador

01

CD-4

Coordenador

01

FG-2

Fonte: Elaborada pela autora, a partir da Resolução 11/2014 do CONSUP (IFPI)

A estrutura organizacional do ensino, representado pelo órgão - PROEN, já foi alterada duas vezes deste da implantação do modelo geral de gestão dos IFs pela Lei 11.892/2008. O Regimento Interno de 2011, que trouxe a composição considerando as pró-reitorias, já foi alterado em 2014, evidenciando uma instabilidade no modelo de gestão adotado ou um ajuste às necessidades de uma instituição que possui múltiplas especificidades. Visto isso, cabe o questionamento: O modelo de gestão não está atendendo as demandas do IFPI, mais especificamente do ensino? Encontra-se aqui o ponto central da investigação. Mas já é evidente que é uma estrutura grande, vários níveis hierárquicos, o que reflete um modelo de gestão burocrático, com execução de tarefas pré-estabelecidas.

\begin{abstract}
A base estrutural é o modelo burocrático de concepção funcionalista, faiolista, com ênfase na produção, entendida aqui como acumulação de "conhecimentos" (entenda-se informações/ reproduções); fechada para o meio exterior, não estabelece troca com ele. A concepção e execução constituem atividades distintas, requerendo competências também diferentes; como decorrência alguns planejam decidem, enquanto outros executam, obedecem. Administrativo e pedagógico estão separados, independentes, constituindo níveis de ação e de autoridade diferentes (VIEIRA. et al, 2003,p.36).
\end{abstract}

A gestão de ensino, que poderia ser algo inovador, percebe-se que traz uma prática enraizada nos princípios da administração burocrática, a qual consiste na reprodução de modelos tradicionais, onde os gestores exaltam a função administrativa, centralizam as ações, dão ênfase no controle e na cobrança por resultados definidos muitas vezes por planejamentos rígidos e distantes do contexto real. 
A centralidade das ações é evidenciada nos verbos que designam as atribuições da PROEN utilizados no Regimento Interno do IFPI, os quais consistem em: analisar, promover, gerenciar, regulamentar, estabelecer, desenvolver, coordenar todo o funcionamento de ensino nos Campi, seja na estruturação dos cursos ofertados no que tange à implantação de projetos institucionais e de projetos pedagógicos dos cursos, reformulação e modernização das matrizes curriculares, na normas e procedimentos nas áreas de ensino, controle acadêmico, organização disciplinar e didática. Enfim, controlam tudo que se refere as ações que impactam o processo de ensino.

Na observação, foi evidenciado que há uma concentração muito grande das informações, na PROEN, o que acaba gerando desencontros de informações, principalmente entre os Campi. A PROEN está ligada a vinte diretorias de ensino, número de Campus do IFPI. Como a estrutura de gestão aplicada ao ensino é a mesma em todos os campi, fica tudo centralizado na PROEN. Até os editais de seleção dos alunos são elaborados nesta Pró-Reitoria, evidenciando uma administração por vezes rígida, um tanto quanto, controladora, em que nada se assemelha com a administração gerencial, modelo adotado na administração pública atual. Vieira. et al. (2010) elencam no modelo de administração técnico-científica as seguintes características:

Detalhamento das funções, reponsabilidades e tarefas a serem realizadas, enfatizando-se a divisão das atividades por cargos e departamentos. Foco nas ações de controle e normatização, favorecendo a perda da visão coletiva e do dirigente sobre os objetivos específicos da instituição. Comunicação linear e vertical, prevalecendo-se da estrutura hierárquica (VIEIRA. et al., 2010, p.46).

Ainda foi possível observar na Pró-Reitoria de Ensino que há uma cooperação muito grande entre os membros da equipe, um colega está disposto contribuir com a atividade de outro, há um cooperativismo evidente. Porém, deu para perceber que a PROEN ainda não dispõe de recursos que poderiam auxiliar muito no desenrolar de suas atividades. Como exemplo, destaca-se a ausência de banco de dados da Pró-Reitoria de Ensino, com as informações atualizadas de todas as Direções de Ensino do IFPI, sua composição, com número de servidores, formação e contato, algo simples, mas que auxiliaria muito o planejamento. 
Em se tratando de planejamento, uma das ações que estavam em andamento, no período da observação era a alteração dos Projetos Pedagógicos dos Cursos superiores, onde a proposta era unificar os projetos para todos os campi que ofertassem aquele curso. Formou-se uma comissão multicampi, ou seja, com uma representação de cada campus, para compor comissão e elaborar as propostas do planejamento unificado. A justificativa ficou por conta de procurar organizar a matriz curricular, visto que havia uma variação muito grande, criar uma identidade do curso no IFPI, facilitar o fluxo de alunos de campus para campus e alinhar os projetos às novas normatizações oriundas do Ministério da Educação. Os projetos de cursos unificados facilitam o acompanhamento da gestão, porém desconsidera as especificidades locais, seus aspectos históricos-sociais, contrariam os princípios do planejamento participativo e democrático, pois não existe a participação dos atores ligados ao curso em sua elaboração. Os vários níveis hierárquicos da POREN centralizam as ações de ensino, seria mais proveitoso se os Campi com base na sua realidade local tivessem capacitação para realizar suas atividades com mais autonomia, realizando seus processos de seleção de alunos, definido seu calendário escolar, caberia à PROEN disponibilizar as diretrizes e os direcionamentos gerais.

A Direção de Ensino (DIREN) é uma unidade organizacional responsável pelo ensino, desde a organização até o monitoramento, não se envolvendo diretamente com as questões administrativas, o que faz desse modelo de gestão supostamente único, pois geralmente as escolas tem gestores que administram todos os aspectos da escola. Aparentemente, é um modelo de gestão inovador, visto que não segue o modelo padrão, porém, a inovação se restringe às múltiplas subdivisões e atribuições, porque as ações e decisões continuam centralizadas e dependes da PROEN.

Para Vieira. et al. (2010), a tendência atual da gestão educacional é caminhar para descentralização, atribuindo à escola, o que no caso do IFPI pode ser considerado cada Campus, maior poder de decisão, conferindo-lhe ao mesmo tempo a responsabilidade pelos resultados finais, ou seja, pelo sucesso ou fracasso escolar.

Na DIREN do campus Corrente, são doze coordenações, relacionadas no Quadro 4, a maioria com gratificações indicadas pelos os códigos CD (Cargo de Direção), FCC (Função de Coordenação de Curso), FG (Função Gratificada), que dão suporte pedagógico, logístico às todas as atividades ligadas ao ensino. Embora haja no Regimento Interno e na Organização Didática do IFPI, princípios da administração 
gerencial, a saber o compromisso em atender com qualidade o cidadão, eficiência nos serviços, controle dos resultados, ainda existe normatizações que são o retrato da administração burocrática, muitos níveis hierárquicos, excesso de formalismo e cargos comissionados que permitem indicações muitas vezes sem critérios técnicos.

Quadro 4 - Estrutura Organizacional da DIREN (IFPI)

\begin{tabular}{|c|c|c|c|}
\hline UNIDADE ORGANIZACIONAL & CARGO/FUNÇÃO & QUANT. & CD/FG \\
\hline 3.3.2 - Diretoria de ensino - DIREN & Diretor & 01 & CD-3 \\
\hline $\begin{array}{l}\text { 3.3.2.1 - Coordenação do Curso de } \\
\text { Gestão Ambiental }\end{array}$ & Coordenador & 01 & FCC \\
\hline $\begin{array}{l}\text { 3.3.2.2 - Coordenação do Curso de } \\
\text { Licenciatura em Matemática }\end{array}$ & Coordenador & 01 & FCC \\
\hline \multicolumn{4}{|c|}{ 3.3.2.3 - Coordenação do Eixo Ambiente, Saúde e Segurança } \\
\hline $\begin{array}{l}\text { 3.3.2.3.1 - Curso Técnico em meio } \\
\text { Ambiente }\end{array}$ & Coordenador & 01 & FCC \\
\hline \multicolumn{4}{|c|}{ 3.3.2.4 - Coordenação do Eixo Informação e Comunicação } \\
\hline $\begin{array}{l}\text { 3.3.2.4.1 - Curso Técnico em } \\
\text { Informática }\end{array}$ & Coordenador & 01 & FCC \\
\hline \multicolumn{4}{|c|}{ 3.3.2.5 - Coordenação do Eixo de Recursos Naturais } \\
\hline $\begin{array}{l}\text { 3.3.2.5.1 - Curso Técnico em } \\
\text { Agroecologia }\end{array}$ & Coordenador & 01 & FCC \\
\hline $\begin{array}{l}\text { 3.3.2.6 - Coordenação das Áreas da } \\
\text { Natureza, Humanas e Letras }\end{array}$ & Coordenador & 01 & FG-1 \\
\hline $\begin{array}{l}\text { 3.3.2.7 - Coordenação de Educação } \\
\text { Física }\end{array}$ & Coordenador & 01 & - \\
\hline $\begin{array}{l}\text { 3.3.2.8 - Coordenação Geral de } \\
\text { Apoio ao Ensino }\end{array}$ & Coordenador & 01 & FG-1 \\
\hline 3.3.2.8.1- Coordenação Pedagógica & Coordenador & 01 & FG-1 \\
\hline $\begin{array}{l}\text { 3.3.2.8.2 - Coordenação da } \\
\text { Biblioteca }\end{array}$ & Coordenador & 01 & FG-2 \\
\hline
\end{tabular}




\subsubsection{3 - Coordenação de Controle Acadêmico \\ Coordenador \\ 01 \\ FG-2 \\ 3.3.2.8.4 - Coordenação de \\ Coordenador \\ 01 Disciplina}

Fonte: Elaborada pela autora, a partir da Resolução 11/2014 do CONSUP.

As atividades da PROEN se resumem na organização das políticas educacionais, propor e elaborar projetos de cursos, acompanhar docentes e discentes, monitorar as atividades acadêmicas, adequar os currículos às exigências do mundo do trabalho, articular e apoiar programas de pesquisa, extensão e promover diagnóstico para investimento na formação e qualificação docente. Pelas atribuições definidas no Regimento Interno, a DIREN não tem autonomia para ação, mas tem que seguir as finalidades e objetivos dos IFs, estabelecidos na Lei no 11.982 de 2011, e que foram traduzidos em programas e projetos controlados pela PROEN, é tão nítida o engessamento da PROEN, que não nenhum tipo de inovação no direcionamento das ações de ensino.

\subsubsection{OD - Organização Didática}

A Organização Didática é um documento norteador de todas as atividades do ensino, especificando desde a natureza da instituição, missão, função social, finalidades, caraterísticas e objetivos, organização curricular, planos e planejamentos, cursos oferecidos, especificação das modalidades dos cursos, bem como regime escolar e a especificidade de acesso, trancamento, reinício, avaliação da aprendizagem para todos e níveis e modalidades, colação de grau, orientações para estágio e trabalhos de conclusão de curso e ainda atribuições docentes, especificando direitos e deveres, bem como direitos e deveres dos discentes. Como é o documento que a PROEN usa para se fazer presente nos Campi, devendo ser seguidos por todos eles, a PROEN busca zelar pelo cumprimento das normas e regras estabelecidas nesta organização. Por se tratar de um documento extenso, elencou-se as categorias relacionadas com os objetivos da pesquisa, segundo o Quadro 5. 
Quadro 5 - Categorias de Análise II

Organização Didática (2015)

\begin{tabular}{llr}
\hline Categoria & Indexadores & Expressão Legal \\
$1-$ Instituição & Especificidade, Estrutura & Art. 2o \\
$2-$ Missão & Institucional & Art. 3o \\
3- Função & Educação, Competência, Social & Art. 5o \\
$4-$ Atribuições & Finalidades, Características & Art. 5o
\end{tabular}

Fonte: Elaborada pela autora, 2015.

Na concepção trazida pela Organização Didática, o Instituto Federal do Piauí é uma instituição de educação superior, básica e profissional ou seja, lida com diferentes níveis de ensino: Ensino Superior e Educação Básica, tendo cada um, sua especificidade. A missão institucional desta autarquia é promover uma educação de excelência direcionada às demandas sociais (IFPI, 2010, p. 3).

$\mathrm{Na}$ observação não participante realizada na PROEN, não ficou explicito em nenhum momento a pretensão de fazer um planejamento que levasse em consideração o que é o IFPI e como dar suporte a cada nível e a cada modalidade de ensino. Na ocasião da observação, duas servidoras a chefe do departamento pedagógico e pedagoga estavam elaborando uma capacitação para as equipes pedagógicas dos Campi, o foco da capacitação era educação inclusiva. O planejamento é feito por haver inquietações dos gestores sobre a temática, ou porque é uma exigência da SETEC e assim segue a PROEN, tentando constituir-se como suporte às demandas do ensino nos Campi.

A função social do IFPI é promover educação científica, tecnológica e humanística, com vistas à formação integral do aluno, com intuito de formar um cidadão crítico-reflexivo, com todas as condições para atuar no mundo trabalho.

As finalidades e características do IFPI são as mesmas estabelecidas na Lei ํㅜ 11.892 de 2008, ou seja, ofertar educação profissional tecnológica em todos os níveis e modalidades, garantindo a verticalização do ensino, com vistas à geração de adaptação de soluções técnicas e tecnológicas às demandas sociais, considerando os arranjos produtivos locais. Ainda, o IFPI tem de promover a capacitação técnica e atualização pedagógica dos servidores, além de desenvolver programas de extensão e pesquisa. 
$\mathrm{Na}$ observação, ficou evidenciado que a PROEN busca seguir os documentos institucionais. Nas conversas internas, os servidores que lá atuam sempre fazem menção aos documentos. Quando um campus vai lançar um edital para atender alguma das atribuições do IFPI, o mesmo tem de ser analisado pela PROEN e depois encaminhado para a publicação. Conclui-se que este é um órgão muito centralizador, haja vista que todas as ações que implicam no ensino passam pela PROEN, mas não é de todo ruim, pois resguardam os Campi de alguma ação que possa ter implicações jurídicas, visto que a PROEN conta com uma equipe bem preparada e com auxílio da Procuradoria do IFPI, que dá todo o suporte jurídico necessário.

\subsection{GESTÃO DE ENSINO NA PERCEPÇÃO DOS GESTORES E DOS DOCENTES}

Foram realizadas entrevistas com a Pró-Reitora de Ensino do IFPI, na Reitoria, sediada em Teresina -PI e com a Diretora de Ensino do IFPI - Campus Corrente, em Corrente - PI. Ambas as entrevistas foram gravadas em áudio e transcritas, para posterior análises. As análises foram realizadas com base em categorias, segundo Bardin (2011) e tabuladas com o auxílio do software Welf QDA, onde foi possível criar uma árvore de categorias e destacar os trechos das entrevistas relacionados com as categorias pré-definidas.

Como as entrevistas foram marcadas com antecedência, não houve nenhum impedimento, seguindo um roteiro elaborado com nove (9) questões norteadoras referentes ao modelo de gestão do ensino, no que diz respeito à estrutura organizacional, as funções e ações. As questões também foram direcionadas ás especificidades dos institutos e, por conseguinte do IFPI. Os aspectos abordados foram modalidades e verticalização do ensino, a relação da oferta com os arranjos produtivos locais, investimento nos docentes, e como o modelo de gestão garante a autonomia da gestão de ensino, como a gestão lida com a avaliação externa, como é feito o acompanhamento e o monitoramento das ações de ensino. Cada questionamento realizado compreendia uma categoria relacionada com os objetivos da pesquisa. As questões foram direcionadas para o âmbito geral que corresponde a PROEN e para o âmbito específico do Campus Corrente. 
A gestão do ensino se materializa em cada Campus, visto que é onde os cursos são ministrados, as aulas são desenvolvidas, enfim, onde atividades do ensino acontecem. Partindo dessa premissa, percebeu-se a necessidade de entrevistar alguns coordenadores de curso, visto que, representam a ponta final da gestão de ensino e também, devido as colocações dos professores no grupo focal, onde voltaram as observações para o contexto mais próximo das atividades da docência. Então, as entrevistas planejadas a priori com o Reitor do IFPI e com o Diretor Geral do IFPI - Campus Corrente, foram substituídas, por questionários abertos, com elaboração de novas questões (Roteiro dos questionários nos apêndices) aplicadas aos coordenadores de ensino.

Além da percepção da gestão de ensino segundo a concepção de seus gestores, buscou-se a percepção dos docentes, haja vista que eles são os responsáveis direto pelo ensino. Para levantar os dados junto aos docentes, optou-se pela realização de um grupo focal. Participaram do grupo focal 8 professores, que foram selecionados com base no critério de um mesmo professor atuar em vários níveis e modalidades educacionais dentro do IFPI - Campus Corrente. Esta parte da coleta de dados ocorreu no próprio campus, na sala de reuniões local que foi previamente organizada. O local dispunha de mesa grande de reuniões, oportunizando que todos ficassem de frente uns para os outros. Também foi instalada uma filmadora. Contou-se, ainda, com o apoio de dois auxiliares: um era o observador e o outro secretário que tomava nota de todas as falas.

\subsection{1 - Discussões}

Apresentamos no Quadro 6 a relação de categorias, oriundas das finalidades e características dos IFs estabelecidas em conformidade com a análise dos documentos apresentados e discutidos anteriormente, bem como a legislação vigente que normatiza estas instituições. 


\section{Quadro 6 - Resumo das finalidades e características do IFs}

Finalidades e Características dos IFs, segundo a

Lei 11.892

Ofertar educação profissional e tecnológica, em todos os seus níveis e modalidades

Verticalização da educação básica à educação profissional e educação superior

Oferecer capacitação técnica e atualização pedagógica aos docentes das redes públicas de ensino;

Processo educativo e investigativo de geração e adaptação de soluções técnicas e tecnológicas às demandas sociais e peculiaridades regionais;

Aspectos Institucionais

Gestão

PIBID, PRAEI

Avalições externas

Ações do ensino
Categorias

Autonomia

Categorias

Modalidades

Verticalização

Aperfeiçoamento docente

Arranjos Produtivos Locais

Ações articuladas ao
processo de ensino aprendizagem

Avaliação

Monitoramento

Fonte: Elaborada pela autora, 2015.

As entrevistas estruturadas foram realizadas com as gestoras da PROEN, a Pró-Reitora de Ensino e da DIREN, a Diretora de Ensino, com a intenção de coletar informações sobre a gestão do ensino, buscando identificar a visão de quem planeja e gerencia as ações nas duas unidades organizacionais do ensino no IFPI, tanto em nível geral, no caso a PROEN, como em nível local, Campus - DIREN.

A Pró-Reitora de Ensino (Nomenclatura que será usada para identificar a entrevistada), está no cargo desde 2013. A formação da Pró-Reitora é Pedagogia, concursada em cargo Técnico Administrativo para o Campus Teresina Central e atua no IFPI há mais de 15 anos.

A Diretora de Ensino (Nomenclatura que será usada para identificar a entrevistada), está também desde 2013 no cargo, passou por um processo de consulta perante à comunidade escolar em 2014, que a reconduziu ao cargo e lá está até o momento. É pedagoga, concursada no IFPI para docente de disciplinas pedagógicas desde 2010. 
Foram três coordenadores selecionados para responder os questionários. A escolha teve como critério a representatividade de cada nível de ensino e/ou modalidade ofertada no IFPI. Ficando um coordenador de Curso do Ensino Médio Integrado, no núcleo específico de Informática (CEMII - Sigla utilizada para identificar o coordenador), um coordenador de curso do Técnico Concomitante/ Subsequente de Agricultura (CTCS - Sigla utilizada para identificar o coordenador) e outro coordenador de curso do Ensino Superior em Licenciatura em Matemática (CES Sigla utilizada para identificar o coordenador).

Todos os coordenadores têm formação na área que coordena. $O$ coordenador de Ensino Médio Integrado é Tecnólogo em Informática / Especialista em Banco de Dados, ingressou no IFPI em novembro de 2014. O coordenador de curso do Técnico Concomitante/ Subsequente de Agricultura é Engenheiro Agrônomo / Mestre em Agronomia, ingressou no IFPI em abril de 2015. E o coordenador de curso do Ensino Superior Licenciatura em Matemática é Licenciado em Matemática / Mestre em Educação, ingressou no IFPI: em agosto de 2014. Pela formação dos coordenadores, tecnólogo, engenheiro, licenciado, percebe-se que a característica multidisciplinar e pluricurricular dos IFs se apresenta desde a seleção dos docentes.

As categorias elaboradas para análise do conteúdo levaram em consideração as características e finalidades dos IFs, segundo a Lei no 11.982 de 2008, pois estas configuram a instituição.

No artigo 6ํinciso primeiro da referida lei, os IFs têm que ofertar educação profissional e tecnológica, em todos os seus níveis e modalidades, então, tem as duas primeiras categorias: Modalidades e Verticalização, destacadas no depoimento dos gestores, conforme Quadro 7.

\section{Quadro 7 - I Depoimentos dos gestores de ensino}

\section{Gestores de Ensino $\quad$ Categoria - Modalidades}

Pró - Reitora Entre os onze mais antigos só Paulistana não tem, não trabalha com Educação Superior, nós só temos 7 Campi que não trabalham com Educação Superior - Paulistana e os seis que iniciaram ano passado, né Oeiras, Cocal, Valença, São João, Pedro II e Campo Maior e os Campi avançados Pio IX e José de Freitas que entraram em funcionamento porque não é a natureza deles trabalharem com Educação Superior. Qual é a finalidade deles? Apenas a educação profissional de nível Técnico e de formação inicial e continuada eles, não vão ofertar, não vão adentrar, nem no integrado, técnico integrado, nem na educação superior. 


\begin{tabular}{ll}
\hline Diretora de Ensino & \begin{tabular}{l} 
Ofato da instituição oferecer várias modalidades, de em uma só instituição \\
oferecer, é ensino médio, é técnico junto ao integrado e na outra \\
modalidade concomitante/subsequente, a educação de jovens e adultos, \\
que é o PROEJA que é um desafio.... \\
Há uma resistência muito grande dentro da instituição, e essa e aqui no \\
campus principalmente aqui no campus, vejo uma resistência muito \\
grande e o ensino superior e você articular todos esses, essas \\
modalidades de ensino. Não é fácil, num só, no só contexto. \\
\\
Vejo alguns professores, mas é com tantas modalidades, tantas etapas, é \\
muito complicado, a gente sabe que é um desafio. Eu cheguei em \\
momento de uma palestra a dizer assim: olha gente quando nós viemos \\
para o instituto nós já sabíamos desse desafio \\
\hline O maior desafio é atender de forma satisfatória a todas as modalidades \\
sem privilegiar uma em detrimento da outra. Percebi, nesta breve \\
experiência, que os cursos subsequentes não recebem a mesma atenção \\
que a direcionada aos cursos integrados, por exemplo. \\
\hline Principalmente manter as atividades de ensino pesquisas e extensão em \\
plena atividade entre docentes e discentes, com a necessidade da \\
contratação de novos servidores técnicos e docentes.
\end{tabular} \\
\hline $\begin{array}{l}\text { Penso que o campus dê prioridade apenas ao Ensino Médio, e se esquece } \\
\text { das outras modalidades. Diversos setores inteiros funcionam apenas em } \\
\text { atendimento às questões desse nível de ensino e se esquecem de que } \\
\text { eles trabalham para coordenar os trabalhos em todos os níveis de ensino. }\end{array}$
\end{tabular}

Fonte: Elaborada pela autora, com base nos depoimentos dos gestores de ensino, 2015.

A LDB destaca que as modalidades de ensino compreendem: educação especial, educação indígena, educação de jovens e adultos, educação a distância e a própria educação profissional e tecnológica. Os IFs têm pelo instrumento legal, que ofertar educação profissional tecnológica em diversas modalidades de ensino, o que representa para os gestores um desafio a ser superado. Segundo os relatos dos gestores de ensino é uma singularidade, difícil de ser contemplada, devido ao fato de conseguir atender ás diversas modalidades com a mesma qualidade e em dado momento uma modalidade será negligenciada. Segundo as colocações dos gestores, um dos motivos seria a falta de servidores necessários para dar o suporte a todas demandas, outra questão que também reside no quadro de pessoal, pois devido as formações serem bastante variadas é comum não haver envolvimento por parte de alguns docentes em algumas modalidades de ensino.

A oferta de múltiplas modalidades se configura num problema para a gestão de ensino. Na visão geral a Pró-reitora, destaca-se que para um Campus 
funcionar é necessário a infraestrutura e os servidores, para tanto é feito um planejamento prévio, com a previsão de cursos a serem ofertados e o quantitativo de professores e técnicos administrativos. Para a gestora, alguns Campi do IFPI, começam com uma oferta de cursos mínimos, só mesmo para garantir o início das atividades. De fato, nota-se a preocupação em dar apenas as condições de funcionamento dos Campi. Mas para os coordenadores, que estão atuando diretamente no processo de ensino, só ofertar as modalidades não garante eficiência do Campus, se faz necessário uma atenção igualitária a todas as modalidades ofertadas. Na opinião de um dos coordenadores participantes da pesquisa, existe nitidamente uma estrutura de funcionários montada preferencialmente para atender o Ensino Médio Integrado, fato que tem gerado um atendimento menos eficiente ás demais modalidades e níveis.

O IFPI atende além do Ensino Médio Integrado, o nível superior, com o Curso de Licenciatura em Matemática e o Tecnólogo em gestão Ambiental em 2016, passará a ofertar Pós-graduação Lato Sensu, nas áreas de Gestão Ambiental e Matemática, configurando a verticalização do ensino.

No grupo focal, do ponto de vista dos docentes, todos 8 acham que a verticalização é um problema a ser superado, pois sentem dificuldades na atuação em sala de aula, devido à necessidade de adequar a linguagem para cada nível de atuação. Um dos professores afirmou que seria necessário um suporte pedagógico maior para um professor que ministra aulas no ensino superior, possa também ministrar no PROEJA, com a mesma qualidade. Três professores veem essa multiplicidade de oferta como uma falta de identidade. De acordo com uma das falas registradas:

O IFPI - Não tem identidade, Instituto Federal é uma instituição ornitorrinco (Professora 1).

Outro problema levantado pelos professores é o fato de estarem ligados ás várias coordenações de cursos e não sabem a quem recorrer, além de causar problemas no momento da distribuição das disciplinas, pois aparentemente os coordenadores não discutem entre si a distribuição das disciplinas dos professores. Apontaram que falta um coordenador de área ou que as coordenações deveriam ser por áreas e não por cursos. 
Assim, é tratada a multioferta no IFPI, como algo desafiador e que precisa de adaptações por parte dos gestores e docentes, Quadro 8.

Quadro 8 - II Depoimentos dos gestores de ensino

Gestores de Ensino Categoria - Verticalização

Pró - Reitora Esse público alvo do técnico integrado são adolescentes em média a idade entre 13 a 16 anos então, o trabalho com eles a abordagem com eles é outra e além do mais tem a questão de além da idade da clientela, tem a questão do curso que é né a parte da formação propedêutica e a parte da formação profissional, então já é uma dificuldade. E o técnico concomitante/ subsequente é um público também diferenciado porque já são mais jovens entre 18 e 24 anos ou mais velhos já outra abordagem por conta da maturidade que eles tem, muitos já trabalham, então já tem a experiência profissional, então temos essa dificuldades e quando tem o técnico e superior. O professor tem ainda maior dificuldade, porque são de naturezas diversas, temos essas dificuldades e a questão da verticalização, a nessa gestão estamos tentando fazer essa verticalização mesmo, desde o técnico, a graduação até a pós-graduação...

Diretora de Ensino $\quad$ A verticalização eu a vejo como positiva sim, porque existe aí um questionamento sobre especializar-se o não... Mas eu vejo isso, como positivo porque é ali que você se torna centro de excelência como está na missão naquela questão, então a gente busca sim essa verticalização, tanto é que já tem a proposta já aprovada de especialização em ensino de matemática, por que é um dos nossos cursos, dos cursos que ofertamos aqui. Então, você verticalizando, você tem a chance maior de manter seu aluno aqui fidelizado à instituição, chegar a ser professor da instituição $e$ nós já temos esse caso. Onde você começa no curso técnico se envereda pelo curso superior e logo, logo você está sendo profissional da casa, então acho que isso é bom é positivo sim, eu vejo a verticalização como muito positiva ou que a gente, não... essa questão do foco é importante, eu vejo alguns, meio perdidos e a gente verifica prejuízos a coisa fica meio solta e verifica prejuízo.

\begin{tabular}{ll}
\hline CEMII & $\begin{array}{l}\text { E bastante difícil para os gestores acompanharem o desenvolvimento de } \\
\text { cursos tão diversos... }\end{array}$ \\
\hline CTCS & $\begin{array}{l}\text { Os Institutos fundamentam-se na verticalização do ensino, onde os } \\
\text { docentes atuam nos diferentes níveis com os discentes, compartilhando } \\
\text { os espaços pedagógicos e laboratórios, também assumem um } \\
\text { compromisso de intervenção em suas respectivas regiões. }\end{array}$
\end{tabular}

CES

A verticalização possibilita ao professor ter acesso a várias modalidades de ensino, podendo transitar entre elas. Permite também a socialização do saber entre diferentes atores, alunos, o que acho muito útil.

Fonte: Elaborada pela autora, com base nos depoimentos dos gestores de ensino, 2015. 
A verticalização é uma das características dos Ifs, que consiste em ofertar cursos do nível da educação básica até a pós-graduação, a oferta se baseia nos eixos tecnológicos, que é uma espécie de linha de formação dentro de uma mesma área de conhecimento científico. Os eixos são definidos por Campus, com ênfase no desenvolvimento local e global.

Ao definir a expertise econômica da região onde o instituto é instalado, estabelece-se os eixos tecnológicos e são definidos os cursos que serão ofertados e em seguida o recrutamento de professores e técnicos administrativos para atenderem a aqueles eixos com os respectivos cursos.

A verticalização do ensino no sentido da sequência dos estudos por nível cada vez superiores é comum à rede privada de ensino, que por meio de grupos empresariais, oferta educação desde a infantil ao ensino superior e ainda com seu próprio livro didático, e também é comum em instituições escolares confessionais, onde existe um segmento religioso que controla o ensino até a universidade.

No caso dos IFs, a proposta de verticalização vai além de uma evolução hierárquica nos níveis de ensino.

\begin{abstract}
Para efeito de compreender o avanço no sentido da verticalização, é importante destacar a proposta curricular que integra o ensino médio à formação técnica (entendendo-se essa integração em novos moldes). Essa proposta, além de estabelecer o diálogo entre os conhecimentos científicos, tecnológicos, sociais e humanísticos e conhecimentos e habilidades relacionadas ao trabalho, além de superar o conceito da escola dual e fragmentada, pode representar, em essência, a quebra da hierarquização de saberes e colaborar, de forma efetiva, para a educação brasileira como um todo, no desafio de construir uma nova identidade para essa última etapa da educação básica (PACHECO, 2010, p.19).
\end{abstract}

No inciso III do artigo 6ํ da Lei nº 11.892 de 2008, para integrar a educação básica à educação profissional e superior faz-se necessário otimizar a infraestrutura física, os quadros de pessoal e os recursos de gestão.

Dos quatro gestores abordados na pesquisa, todos são unânimes em afirmar que a verticalização é positiva, por razões diferentes: por permitir ao professor contato com alunos de diferentes faixas etárias, com troca de experiências, vivências; por possibilitar uma rica de troca de saberes e utilização comum dos espaços educativos. Quanto à infraestrutura física, há consenso de que ela favorece a verticalização, embora em alguns momentos haja disputas de laboratórios, auditórios, mas nada que comprometa o andamento das atividades. Outro aspecto positivo 
levantado foi a possiblidade de o aluno também verticalizar sua carreira dentro da instituição, finalizar sua formação básica e poder chegar à pós-graduação, ou em alguns casos até segui uma carreira profissional dentro do próprio instituto, como já houve um caso no Campus Corrente.

Na visão dos docentes, a verticalização é algo positivo, pois possibilita ao aluno crescer na instituição. Os alunos do ensino médio podem se beneficiar com a divisão dos espaços com alunos de outros níveis e faixa etárias diferentes. Percebese, aqui, uma contradição, pois em relação a ofertar várias modalidades todos os professores pesquisados são contra. Mas quanto à ideia de verticalização, não só consideram a ideia positiva, como a defendem, com a ressalva de que os gestores precisam articular a relação do ensino superior com o ensino médio.

Mas a verticalização, na prática, apresenta problemas que estão relacionados ao quadro de pessoal. Segundo os gestores pesquisados, destacam o fato de a clientela apresentar diferentes faixas etárias, com expectativas de vida diferentes de um nível para outro, o que prejudica a atuação do professor, pois esse não consegue se adequar plenamente, na linguagem, na didática, aos diferentes contextos dos níveis de ensino. Já outra dificuldade levantada se relaciona à gestão, no que diz respeito ao acompanhamento do trabalho docente. A gestão de ensino entende que deve haver um acompanhamento mais criterioso da atuação docente, para não ficar um trabalho muito "solto", mas não sabe bem como isso deve acontecer no dia-a-dia. Outra dificuldade para a gestão reside no acompanhamento de todos os cursos ofertados e como responder às demandas específicas, já que cada curso tem suas próprias especificidades.

A categoria Arranjos Produtivos Locais está ligada a outra característica dos IFs, que é articulação dos cursos com o potencial econômico e desenvolvimento da região, no Quadro 9, retrata a opinião dos gestores sobre o assunto.

\section{Quadro 9 - III Depoimentos dos Gestores de ensino}

\begin{tabular}{ll}
\hline Gestores de Ensino & \multicolumn{1}{c}{ Categoria - Arranjos Produtivos Locais } \\
\hline Pró -Reitora & $\begin{array}{l}\text { A instituição já tem um direcionamento e dá outro direcionamento a partir } \\
\text { dos outros campi, então a gente tem que ter muito cuidado com isso há } \\
\text { uma tendência muito grande de fugir dos arranjos produtivos locais e a } \\
\text { gente tem ter muita fidelidade a essa questão dos arranjos produtivos } \\
\text { locais para que a gente possa realmente ouvindo a comunidade local a } \\
\text { comunidade regional perceber o que de fato necessita. }\end{array}$
\end{tabular}




\begin{tabular}{ll}
\hline Diretora de Ensino & $\begin{array}{l}\text { Você chegar nos arranjos produtivos locais essa uma questão muito, eu } \\
\text { diria um pouco fragilizada né a questão dos arranjos produtivos locais e } \\
\text { que a gente precisa está mais em interação com a comunidade para } \\
\text { descobrir de fato o que ela quer. }\end{array}$
\end{tabular}

Fonte: Elaborada pela autora, com base nos depoimentos dos gestores de ensino, 2015.

Na busca de alinhar sua oferta de curso ás necessidades do contexto, onde está inserido, os Ifs consideram os arranjos produtivos locais.

\begin{abstract}
Arranjos Produtivos Locais (APLs) são caracterizados por aglomerações de empresas localizadas em um mesmo território, que apresentam especialização produtiva e mantêm vínculos de articulação, interação, cooperação e aprendizagem entre si e com outros atores locais, tais como governo, associações empresariais, instituições de crédito e ensino e pesquisa (VIEIRA, 2010, p.10).
\end{abstract}

Na percepção das gestoras de ensino, o planejamento da oferta de cursos deve realmente estar alinhado aos arranjos produtivos locais, como estabelece a lei de criação dos IFs, pois ao considerar os anseios da comunidade, seu potencial, não só haverá procura pelos cursos ofertados sejam técnico integrado ao médio, concomitante/subsequente e ou ensino superior, como também haverá uma instituição de ensino que contribuirá para o desenvolvimento social, econômico e comunidade. Para a diretora de ensino, a relação do IFPI - Campus Corrente com os arranjos produtivos locais é ainda frágil. Na opinião da mesma, é necessária uma aproximação maior com a comunidade local, estreitar o diálogo para saber de fato o que a comunidade espera do Instituto.

Nas discussões no grupo focal, um professor externou que o IFPI é plural e por isso deve estar bem alinhado com as demandas locais, para fazer mais sentido de existir naquele local.

É comum no planejamento de cursos a serem ofertados, considerar relatórios técnicos da região, estudos que sinalizam o potencial produtivo, porém pode não significar o anseio da comunidade. Já houve casos no IFPI em que houve a oferta de um curso em que a demanda por trabalhadores com aquelas competências e habilidades específicas era muito grande na região, porém havia pouca procura por parte dos alunos e também um índice muito elevado de evasão ou de abandono. Uma reflexão sobre a falta de diálogo com a comunidade para justificar o porquê de a 
procura pelo curso ser baixa, talvez porque a comunidade desconhecia o potencial do curso para a região.

Para os Ifs, não basta estarem na comunidade. É necessário fazer parte dela, com trocas de informações que beneficiam a todos, em um projeto de educação que faça sentido real, que não seja só teórica, com excessos de informações, mas que respeite o potencial produtivo, estimule-o a ponto de desenvolver o protagonismo da população local. Dowbor (2003) defende que,

\begin{abstract}
A educação não pode se limitar a constituir para cada aluno um tipo de estoque básico de conhecimentos. As pessoas que convivem num território têm de passar a conhecer os problemas comuns, as alternativas, os potenciais. A escola passa assim a ser uma articuladora entre as necessidades do desenvolvimento local, e os conhecimentos correspondentes. Não se trata de uma diferenciação discriminadora, do tipo "escola pobre para pobres": trata-se de uma educação mais emancipadora na medida em que assegura ao jovem os instrumentos de intervenção sobre a realidade que é a sua (DOWBOR, 2003, p.5).
\end{abstract}

Com a política de expansão, os IFs se espalharam pelo Brasil, chegando aos interiores de todos os estados, facilitando realmente o diálogo com as comunidades locais. No entanto, considera-se que só se consolida esse estreitamento se os gestores tiverem um direcionamento planejado das suas ações e intervenções, caso contrário essas intuições com prédios suntuosos se tornarão "elefantes brancos", sem sentido, pouco funcional e muito oneroso.

O termo autonomia é muito recorrente, quando se trata de gestão de uma instituição educacional. No caso IFPI, a autonomia é evidenciada pela gestão de ensino, conforme se observa o que se aponta no Quadro 10.

\title{
Quadro 10 - IV Depoimentos dos gestores de ensino
}

\section{Gestores de Ensino Categoria - Autonomia}

$\begin{array}{ll}\text { Pró - Reitora } & \text {...nós somos Multicampi e os campi tem autonomia, autonomia não é } \\ & \text { independência, autonomia é essa corresponsabilidade e se não, não } \\ \text { temos uma identidade, porque nós somos o Instituto Federal, antes de } \\ \text { qualquer coisa, Instituto Federal do Piauí, Campus Corrente, mas é } \\ \text { Instituto. }\end{array}$

Diretora de Ensino Não fez menção sobre o assunto. 


\begin{tabular}{ll}
\hline CEMII & $\begin{array}{l}\text { Sim, a Diretoria de Ensino incentiva projetos e ações da coordenação, } \\
\text { apenas monitora e apoia os projetos para que ocorram de acordo com as } \\
\text { diretrizes da Instituição. }\end{array}$ \\
\hline CES & Não elabora nenhum projeto para nenhum dos campi, que ficam por isso, \\
& impossibilitados de realizarem qualquer tipo de intervenção ou mudança \\
& estrutural em seu espaço físico. Do mesmo modo, os campi não têm \\
& autonomia de decidirem que cursos vão abrir, com que carga horária, qual \\
& o formato de sua grade etc. Não, penso que temos atribuições impostas \\
& pelas DIREN, as quais dá como desculpa as demandas da PROEN e os \\
& coordenadores devem apenas executá-las.
\end{tabular}

Fonte: Elaborada pela autora, com base nos depoimentos dos gestores de ensino, 2015.

A Pró-Reitora afirma que os Campi são autônomos, porém destaca que não são independentes, haja vista fazerem parte da mesma instituição - IFPI. Destacou na entrevista que os Campi participam por meio de comissões quando existem mudanças a serem feitas, nos PPC (Projetos Pedagógicos dos Cursos), na Organização Didática ou quando da necessidade de elaboração de projetos que impactam o ensino. Um detalhe importante, que cabe destacar, é que na maioria das vezes quem faz parte das comissões é o próprio Diretor de Ensino. Quando é formada uma comissão para reformulação de documento, a PROEN a priori elabora uma minuta que é encaminhada aos Campi para as discussões e alterações ou propostas. A autonomia aqui reside no fato de oportunizar as discussões nos Campi, mas depois é feito um resumo de tudo que foi discutido nos campi, por comissão multicampi, ou seja com representações de alguns Campi.

A Diretora de Ensino não fez menção sobre a autonomia do Campus. Já os coordenadores, dois fizeram referência à autonomia enquanto coordenador e sua relação com a Direção de Ensino, sendo que ambos afirmaram ter espaço para elaborarem projetos e ações que são relevantes para o curso. Um dos coordenadores foi mais enfático, destacou a autonomia enquanto campus, em relação à PROEN e em relação a sua própria coordenação. Segundo o coordenador, o Campus não pode escolher o curso a ser ofertado, nem definir currículo, horário de funcionamento. Até na estrutura física há limitações quanto às mudanças. No contexto local, afirma que algumas atribuições são "impostas" pela Direção de Ensino, e esta por sua vez alega ser demanda da Pró-Reitoria de Ensino e os coordenadores devem "executar" as determinações. Então a autonomia fica mais no campo das ideias do que na prática. 
Existem posicionamentos sobre autonomia que estão mais ligados à uma concepção de controle sobre os recursos financeiros, ou seja, o gestor administrar as finanças. O que não ocorre na gestão de ensino do IFPI, a nível de PROEN, a PróReitora afirma:

\begin{abstract}
Eu não tenho recurso, eu administrando, eu gerenciando, mas a gente tem essa articulação com a PROAD, todos os recursos ficam na PROAD, PROEX e a $P R O P I$ ainda tem em recursos específicos, para os projetos de extensão $e$ os projetos de pesquisa. O da Pró-Reitoria de Ensino vem como funcionamento do ensino.
\end{abstract}

Percebe-se que os recursos do ensino não são descentralizados, mas segundo a Pró-Reitora, existem planejamentos no início de cada ano comercial, onde são definidos os projetos, o orçamento das atividades e a PROAD (Pró-Reitoria de Administração) empenha os recursos e vai liberando de acordo com as demandas. $\mathrm{Na}$ avaliação da gestora de ensino, não há nenhum tipo de percalços e não faltam recursos para as atividades do ensino.

A nível de DIREN, a gestora de ensino também não administra nenhum tipo de recurso financeiro. A mesma não fez referência sobre o assunto na entrevista.

Em outra concepção, a autonomia é entendida como agir fora do sistema, criar suas próprias regras. Então, como pode ser entendida a autonomia?

\begin{abstract}
Por certo, trata-se a autonomia de um conceito complexo, com múltiplas nuances e significados, tantos quantos esforços existem para expressá-la na realidade escolar. Algumas vezes, porém, ela é muito mais uma prática de discurso do que uma expressão concreta em ações objetivas: em outras, representa o discurso utilizado para justificar práticas individualistas e dissociadas do contexto. Mas é fundamental que se desenvolva um entendimento comum sobre o mesmo, uma vez que, a partir dele, são organizados programas de ação que influenciam, explicam e legitimam ações de repercussão social muito grande (LÜCK, 2000, p.20).
\end{abstract}

No campo educacional, a autonomia é fundamental no modelo de gestão gerencial. Onde as decisões são compartilhadas, há todo um investimento nas relações de poder para fortalecer a escola, que por sua vez deve estar comprometida com a sociedade " tendo como objetivo a melhoria da qualidade do ensino" (LÜCK, 2000, p.21).

Autonomia é a característica de um processo de gestão participativa que se expressa, quando se assume com competência a responsabilidade social de promover a formação de jovens adequada às demandas de uma sociedade 
democrática em desenvolvimento, mediante aprendizagens significativas (LÜCK, 2000, p.20).

A autonomia de uma instituição escolar é algo complexo, que não se estabelece por atos administrativos. Trata-se de um processo lento, gradual, implica uma politização dos atores escolares. Tal politização deve acontecer no tocante às concepções filosóficas e ideológicas quanto do papel social da escola.

A legislação da educação brasileira estabelece a autonomia como um princípio institucional, embora não haja uma regulamentação mais detalhada, mas afirma que a autonomia reside na abertura de espaços de decisões colegiadas, pelos órgãos deliberativos e consultivos, como conselhos representativos e também no processo de escolha dos diretores, por meio de eleições. Para a autonomia se consolidar enquanto ato administrativo recorrente, faz-se necessário lançar mão de mecanismos que a materializem enquanto ação e prática institucionais.

Para a prática da autonomia escolar, alguns mecanismos são explicitados: existência de estrutura de gestão colegiada, que garante a gestão compartilhada; a eleição de diretores e a ação em torno de um projeto políticopedagógico (LÜCK, 2000, p.22).

A atuação dos gestores no processo de construção da autonomia da escola é preponderante, pois através de suas ações, possibilitam o compartilhamento das decisões, ouvem todos segmentos administrativos, além de se mostrarem acessíveis às críticas e às sugestões de servidores, alunos, enfim, o seu público alvo. Trata-se, além disso, de lidar com o projeto político pedagógico como uma ferramenta de gestão e não como um documento burocrático. No contexto atual, se o gestor não articular sua atuação com vista a autonomia institucional, poderá vivenciar situações conflituosas, inviabilizando a administração.

A gestão de ensino desenvolve suas ações também por meio de projetos e programas que visam impactar positivamente o processo de ensino-aprendizagem. Com destaque, no Quadro 11, algumas ações desenvolvidas pela gestão de ensino do IFPI.

Quadro 21 - V Depoimentos dos gestores de ensino 


\begin{tabular}{ll}
\hline Pró - Reitora & Por exemplo uma política para o ensino que a gente institucionalizou \\
desde do ano passado que é o PRAEI. o que é o PRAEI? Como a gente \\
observou que a maior taxa de retenção e evasão, retenção é na 1 série, \\
fomos identificar porque é na 1 série? Porque eles têm dificuldades de \\
acompanhar, eles veem com a fragilidade na formação, eles têm \\
dificuldade de acompanhar física, química e matemática, porque no \\
ensino fundamental eles não tem separado, quem é de escola pública e \\
nosso maior público é de escola pública. \\
\\
PIBID está relacionado com a Pró-Reitoria de ensino. Um dos programas \\
nossos, além do PIBID de fortalecimento das licenciaturas nós temoso \\
\\
PIBID, nós temos aproximadamente 600 bolsistas no IFPI como um todo. \\
\\
O Pró-docência é um programa da Capes, que visa à elevação da \\
qualidade dos cursos de formação para o magistério da Educação Básica, \\
e a valorização docente, por meio de capacitação.
\end{tabular}

Diretora de Ensino Não menciona nada a respeito.

CEMII Não menciona nada a respeito.

CTCS Não menciona nada a respeito.

CES Não vejo ações efetivas que conduzam a tais iniciativas de melhoria.

Fonte: Elaborada pela autora, com base nos depoimentos dos gestores de ensino, 2015.

Este ponto da pesquisa foi bastante curioso, por se tratar da gestão do ensino e cuja abordagem foi a respeito das ações articuladas ao processo de ensino aprendizagem, pensava-se que teria uma lista enorme com muitas e muitas ações elencadas. Ao contrário dessa expectativa inicial, somente a pró-reitora elencou alguns poucos projetos institucionais voltados para melhoria do processo de ensinoaprendizagem. Os projetos geralmente são únicos para todo o instituto, os campi reproduzem-nos com adequações para suas realidades. Embora os Campi tenham autonomia para desenvolver os seus projetos de intervenção no ensino, o Campus Corrente não apresentou nenhum, fora os institucionais, oriundos da Pró- Reitoria de Ensino. Isso ficou ainda mais evidenciado na constatação do coordenador de ensino superior, que afirmou não ver ações que conduzem a iniciativas de melhorias.

É consenso entre os educadores e cientistas da educação que a qualidade do ensino perpassa pelo investimento na qualificação docente.

Uma escola de qualidade se efetiva mediante um quadro de profissionais qualificados e compromissados com a aprendizagem dos alunos. A definição 
do que seja um ensino de boa ou de má qualidade passa pela relação direta entre a boa formação dos profissionais (BIASI,2009, p.40).

A qualidade do trabalho docente, perpassa pela sua formação e seja a formação inicial ou continuada há de considerar sua prática, visto que, os docentes estabelecem relações com vários saberes, como afirma Tardif (2014)

Pode-se definir o saber docente como um saber plural, formado pelo amálgama, mais ou menos coerente, de saberes oriundos da formação profissional e de saberes disciplinares, curriculares experienciais (TARDIF, 2014, p.36)

No IFPI, a qualidade do professor é alvo de muitos investimentos, conforme

Quadro 12.

Quadro 12 - VI Depoimentos dos gestores de ensino

Gestores de Ensino Investimento no Docente

Pró - Reitora Vejo que positiva que a gente pensa que o mestrado e o doutorado é suficiente, mas esses cursos de formação continuada, bem pontuais ajudam demais na prática, abordagem dos conteúdos, a questão da metodologia. Aperfeiçoamento de professores, capacitação: existem muito investimento como pró-docência capacitação, a gente está fazendo

Diretora de Ensino Eu vejo um investimento na capacitação, na qualificação docente , capacitação, na qualificação dos técnicos né, vejo essa preocupação dos institutos, aí, aí existe até uma crítica atual do próprio institutos , que nas qualificações mestrados e doutorados, está se priorizando técnicos e não professores do ensino superior e as vezes os professores do ensino básico mesmo e a gente tem essa preocupação e a gente tem essa preocupação, por que percebe-se pelas avaliações externas principalmente do ensino superior e são mais rigorosas embora no técnico, também esteja próximo a acontecer que deveria existir essa preocupação, e eu não vejo o instituto com essa preocupação é ofertado de igual para igual, não desacreditando, não tirando o mérito dos técnicos, mas vejo que uma, não existe uma preocupação voltada para o ensino superior, que nesse momento deveria existir em relação a isso e muitos professores estão deixando de ser capacitados, qualificados alias e alguns técnicos estão sendo qualificados e que não vão utilizar aquela qualificação dentro do instituto, então, eu vejo que eles não estão preocupados com isso e eu vejo que devem se preocupar urgentemente né, mas que a qualificação, a capacitação ela gera resultados positivos sim.

CEMII As principais ações desenvolvidas atualmente são os encontros pedagógicos e o incentivo a participação em cursos de aperfeiçoamento.

CTCS

Por enquanto só conheço os cursos oferecidos em parceria de algumas universidades como o UFPI em parceria com o IFPI para que professores possam fazer especialização, mestrado e doutorado, mas este não é um processo fácil na verdade percebo que é dispendioso e desgastante e 
muitas vezes até desestimulante para o professor levando esse muitas vezes a desistir.

Fonte: Elaborada pela autora, com base nos depoimentos dos gestores de ensino, 2015.

Quando se trata de intervenções para melhoria do processo ensinoaprendizagem, a qualificação do trabalho docente deve ser priorizada,com investimentos na formação inicial e continuada.. O IFPI tem como política institucional de investir na formação docente. Para a Pró-Reitora, a formação continuada é um elemento motivacional importante, mas acredita que o mestrado e doutorado não são suficientes, defende que as capacitações dos docentes têm um aspecto mais prático de aplicação rápida e objetiva. Como exemplo citou a questão da metodologia de ensino, que na sua concepção ajuda demais na prática. Destacou um programa de capacitação denominado Pró-docência, que se trata de Programa de Consolidação das Licenciaturas, em parceria com a CAPES, com a finalidade de elevação da qualidade dos cursos de formação para o magistério da Educação Básica e também fomentar à inovação, na perspectiva de valorização da carreira docente.

A Pró-Reitora ainda deixou claro que a Pró-Reitoria de Ensino não conta com recursos para formação a nível de mestrado e doutorado. Estes são programas que estão vinculados à Pró-Reitoria de Pesquisa. Porém a Diretora de Ensino ressalta, que o IFPI não tem priorizado a melhoria da formação docente. Segundo a mesma, os técnicos administrativos estão sendo priorizados nos programas de mestrados e doutorados e que muitas vezes não irão aplicar as competências essa formação diretamente para melhoria das suas ações desenvolvidas no IFPI. Também externou que não existe por parte do IFPI uma preocupação em qualificação que gere resultados para a instituição. Em destaque, a educação superior é tratada pela gestão como qualquer outro nível de ensino e não prioriza a formação dos professores que atuam nesse nível de ensino, porém quando o ensino superior é avaliado, uma das questões pontuadas é exatamente a formação e qualificação docente.

Numa visão mais restrita ao Campus Corrente, segundo um dos coordenadores, as principais ações desenvolvidas com vistas à qualificação docente são os encontros pedagógicos e o incentivo à participação em cursos de 
aperfeiçoamento. Outro coordenador enfatizou que desconhece os programas de qualificação docente, sabe de algumas parcerias com instituições de educação superior para especialização de professores, mas destaca que o processo de seleção é desgastante e desestimulante. O CES destaca que a Equipe Pedagógica até envia por e-mail textos, com ênfase na qualidade do ensino, mas em sua avaliação, estes são de caráter duvidoso.

Em relação a essa discussão da relevância e adequação de formação docente para prática profissional, Tardif (2014) defende a prática profissional, como um espaço original e autônomo de aprendizagem e de formação para os futuros profissionais e para os professores experientes um espaço de produção de saberes e práticas inovadoras. "Esta concepção exige, portanto, que a formação profissional seja redirecionada para a prática e por conseguinte, para a escola enquanto lugar de trabalho dos professores" (TARDIF, 2014, p.286). As instituições de formação de professores devem manter um diálogo constante entres os saberes da profissão docente com a prática profissional.

Concretamente, esse modelo comporta a implantação de novos dispositivos
de formação profissional que proporcionam um vaivém constante entre a
prática profissional a formação teórica, entre os professores e os formadores
universitários. Na maioria dos países que seguiram esse modelo, esses
novos dispositivos de formação tomam ou tentaram tomar forma em novas
organizações (escolas profissionais da Inglaterra, escolas associadas no
Quebec, Professional Development Schools nos Estados Unidos, Mafpen na
França, etc) que proporcionaram uma junção orgânica entre a formação
universitária e o exercício da profissão (TARDIF, 2014, p.286).

Pelas considerações dos gestores pesquisados e pelo modelo de formação proposto por Tardif (2014), os IFs poderiam abarcar bem esse modelo, uma vez que além da formação profissional tecnológica, também se configura como espaço de formação de professores, visto que oferta cursos de licenciaturas. Além disso, ainda pode ser o espaço de formação continuada de seus próprios profissionais, pois já dispõe de estrutura física e de pessoal para tanto. "A formação dos professores supõe um continuum no qual, durante toda a carreira docente, fases de trabalho devem alternar com fases de formação contínua" (TARDIF, 2014, p. 287).

No Quadro 13, a exposição de como ocorre esse processo de monitoramento e acompanhamento por parte dos gestores do ensino do IFPI.

\section{Quadro 13 - VII Depoimentos dos gestores de ensino}




\begin{tabular}{ll}
\hline \multicolumn{1}{c}{$\begin{array}{c}\text { Gestores de } \\
\text { Ensino }\end{array}$} & \multicolumn{1}{c}{ Categoria - Acompanhamento das ações } \\
& \\
\hline Pró - Reitora & $\begin{array}{l}\text { Esse é o nosso grande problema por conta da distância então é difícil a } \\
\text { gente fazer a visita in locus, mas está no plano de ação da PROEN o } \\
\text { acompanhamento das ações. }\end{array}$ \\
\hline Diretora de Ensino & $\begin{array}{l}\text { Anteriormente ouvindo todos os campi em articulação eu acredito que há } \\
\text { como melhorar esse trabalho, mas ele ainda não é bom, nós ainda temos } \\
\text { desencontro de comunicação, nós ainda temos desencontro de ações, }\end{array}$ \\
& $\begin{array}{l}\text { nós ainda temos resquícios de açóes anteriores que prejudicam em } \\
\text { relação aos documentos já elaborados que amarram questões que, não } \\
\text { mais atuais, não respondem a necessidade mais, assim, está sendo um } \\
\text { processo de construção. }\end{array}$ \\
\hline CEMII & $\begin{array}{l}\text { O monitoramento acontece através do envio de relatórios e reuniões } \\
\text { periódicas, geralmente ao final de cada bimestre. }\end{array}$ \\
\hline CTCS & $\begin{array}{l}\text { Não vejo parâmetros institucionais para a verificação da qualidade do que } \\
\text { vem sendo executado em relação a cada campus e se cada um deles } \\
\text { atende a requisitos mínimos de ensino }\end{array}$ \\
\hline CES & $\begin{array}{l}\text { Não vejo tais ações serem monitoradas nem avaliadas. Vejo às vezes } \\
\text { críticas nem sempre bem fundamentadas sobre o trabalho que se } \\
\text { desenvolve. }\end{array}$ \\
\hline
\end{tabular}

Fonte: Elaborada pela autora, com base nos depoimentos dos gestores de ensino, 2015.

Uma das atribuições de qualquer gestor, independe da área de atuação é monitorar e avaliar o processo pelo qual é o responsável. Para a Pró-reitora, aqui está o ponto muito sensível, um problema mesmo. Como o IFPI é muito grande, o monitoramento das ações in lócuo se torna impraticável. A pró-reitora admite que acompanhar as ações nos Campi é uma das metas do Termo de Acordos e Metas ${ }^{8}$ dos IFs.

O Termo de Acordo e Metas estabelece que os IFs assumam 0 compromisso de priorizar esforços e investimentos para cumprir ações que comtemplem na área do ensino a verticalização, a oferta de várias modalidades, com redução das taxas de evasão e repetência, para isso é condição imperativa o monitoramento e acompanhamento das ações.

\footnotetext{
${ }^{8}$ Termo de Metas e Compromissos significa um acordo celebrado que entre si celebram a União, representada pelo Ministério da Educação, por intermédio da Secretaria de Educação Profissional e Tecnológica, e o Instituto Federal de Educação, Ciência e Tecnologia do Piauí, para os fins de estruturação, organização e atuação dos Institutos Federais criados pela Lei no 11.892 de 29 de dezembro de 2008.
} 
A Diretora de Ensino admite que o monitoramento e acompanhamento das ações por parte da Pró-Reitoria é prejudicado devido a falhas na comunicação. Também destaca que muitos servidores da Pró-Reitoria não assimilaram os novos conceitos e concepções de ensino e aprendizagem e que estão acomodados em procedimentos oriundos do antigo CEFET, como por exemplo adequar sua linguagem às várias modalidades de ensino e não conseguiram incorporar nas suas práticas as novas configurações do IFPI.

Para os docentes, o acompanhamento é mecânico e incipiente, pois em relação ao trabalho docente se restringe à análise de diários. Projetos e ações não são avaliados.

As avalições externas a que o IFPI é submetido podem evidenciar alguns pontos fortes do ensino ou algumas fragilidades. O essencial é refletir e discutir os resultados para implementar as ações de ensino. No Quadro 14, expõe-se como as gestoras de ensino lidam com as avalições externas.

\section{Quadro 14 - VIII Depoimentos dos gestores de ensino}

\begin{tabular}{ll}
\hline Gestores de Ensino & \multicolumn{1}{c}{ Categoria - Avaliações Externas } \\
\hline Pró - Reitora & $\begin{array}{l}\text { Avaliação externa que identifica qualidade - sim no caso da educação } \\
\text { básica é o ENEM, no caso da educação superior nós temos os } \\
\text { reconhecimentos de curso, no início desse ano por exemplo nós tivemos } \\
\text { oito ou foram nove reconhecidos pelo MEC. }\end{array}$ \\
\hline Diretora de Ensino & $\begin{array}{l}\text { Eu vejo a avaliação externa como positiva a gente tem que ter algo que } \\
\text { balize nossas ações e as avalições é esse nosso balizador das nossas } \\
\text { ações a gente percebe se está acetando se está se não está. Então o } \\
\text { ENADE a gente ainda tem resultados bastante promissões a gente } \\
\text { poderia ter resultados melhores, mas a gente sabe que também foi um } \\
\text { início }\end{array}$
\end{tabular}

Fonte: Elaborada pela autora, com base nos depoimentos dos gestores de ensino, 2015.

Toda instituição educacional está sujeita às avaliações externas. No caso do IFPI, ela acontece no ensino médio integrado, cujo instrumento de avaliação é o ENEM, e no ensino superior por meio do ENADE. Uma característica comum entre ambas é que são direcionadas aos alunos e estas atestam a qualidade do ensino, por meio de seu desempenho. Também há avaliação dos cursos superiores para o reconhecimento junto ao MEC, uma vez que a instituição oferta educação superior a 
pouco tempo. Neste caso, a avaliação se restringe à instituição nos aspectos estruturais, organizacionais e didáticos. A gestão de ensino percebe a avaliação externa como positiva, pois identifica a qualidade das ações, oportuniza reflexões, sugere mudanças, enfim, ratifica os acertos, expõe as fragilidades e fornece matéria para o planejamento institucional.

Na lógica da política neoliberal, que tem deixado suas marcas no contexto educacional, a avaliação é um instrumento usado para verificação da qualidade do serviço. Não é à toa que as organizações mundiais de educação defendem e sugerem a implantação de uma política de avaliação. No Brasil, todos os níveis da educação, desde o ensino fundamental, até o ensino superior são submetidos a uma avaliação externa.

\begin{abstract}
A hegemonia das políticas neoliberais provocou a contínua provocando forte impacto sobre a educação, a universidade e a avaliação institucional. Os grandes organismos internacionais de suporte dessa doutrina, notadamente - Banco Mundial, elaboraram propostas para a educação no marco da globalização, compreendendo a avaliação institucional como parte ativa das estratégias a serem desenvolvidas (SOBRINHO, 1998 p.3).
\end{abstract}

É mister não observar as avaliações externas só como uma resposta a todo um trabalho realizado. Há que se considerar que a avaliação não é neutra, é um "instrumento de medida e controle, ou seja, é usada para responder às expectativas de eficiência e produtividade" (Sobrinho, 1998). Nesse contexto, a avaliação tem como objetivos:

[...] promover o ajuste do sistema, hierarquizar instituições, cursos ou grupos, instrumentalizar os diversos tipos de financiamentos, apoios e processos de credenciamento e descredenciamento, com base em critérios de eficiência, utilidade, rentabilidade e competitividade e tendo em vista metas preestabelecidas. (SOBRINHO, 1998 p.4)

Cabe refletir até que ponto uma avaliação de "cima para baixo, de fora para dentro" (Sobrinho, 1998), é suficiente para atestar a eficiência de um nível de ensino ou de uma instituição.

Considerando todas as categorias e alinhando-as com dados levantados na pesquisa, alguns obstáculos e desafios para a gestão de ensino do IFPI foram evidenciados. Em se tratando da oferta de várias modalidades, para a PROEN o desafio é organizar a oferta em todos os Campi, de forma que atenda ao planejamento 
estratégico do IFPI e alcance as metas estabelecidas no Termo de Metas e Compromissos firmado entre o IFPI e a SETEC/MEC. Para a DIREN, um dos obstáculos na oferta de várias modalidades é o professorado, pois existe uma resistência de trabalhar com algumas modalidades de ensino. No Campus Corrente a Diretora de Ensino, expressou que o PROEJA (Programa Nacional de Integração da Educação Profissional com a Educação Básica na Modalidade de Educação de Jovens e Adultos) deixou de ser ofertado por não haver nenhum professor disponível para trabalhar com essa modalidade e a alegação era porque não se sentiam preparados para tal modalidade.

O desafio da verticalização do Ensino para PROEN é implementar em todos os Campi, visto que tem alguns que só estão ofertando cursos de formação inicial e continuada de trabalhadores, são cursos de curda duração. Para a DIREN do Campus Corrente foram evidenciados dois desafios, um é em relação aos docentes, alguns até aceitam a verticalização com algo inovador e estratégico, no depoimento de professara no grupo focal afirma:

Professor 5 ( C):

\begin{abstract}
Eu acho que um dos objetivos dos institutos ao verticalizar é garantir a permanência do aluno e consequentemente o aprimoramento dele nesses conhecimentos, você tem alunos que ele entra no ensino médio, ele entra na graduação, ele passa graduação e entra na especialização então ele dar continuidade ao ensino dentro do próprio instituto.
\end{abstract}

Mas por outro lado, alegam que não sabem como agir na prática, conforme relato do grupo focal.

Professora $3(\mathrm{~J})$ :

(...) nós precisaríamos talvez de suporte pedagógico, de orientações. Porque você entra no Instituto Federal, sabe que é educação técnica chega aqui vai do PROEJA da alfabetização quase à especialização, a gente fica com esses entraves e fica sofrendo sozinha, porque não tem ninguém que oriente quanto a isso, você vai dá aula dessa disciplina pronto, sua disciplina é essa.

Assim o desafio é instrumentalizar os professores da instituição para atuarem em todos os níveis de ensino. O outro desafio é adequação dos serviços, como por exemplo a biblioteca funcionar em todos os turnos, por que devido a verticalização o IPFI Campus Corrente funciona em três turnos, e os serviços não contemplam todos os cursos em todos os turnos. 
Para a PROEN, e para DIREN, o desafio na questão dos arranjos produtivos locais, não só considerá-los no momento de planejamento das ofertas de curso, como também estar mais perto das comunidades para de fato atender os anseios da população e não cair no erro de só considerar os arranjos produtivos locais e oferta um curso onde a procura seja mínima ou inexistente.

$\mathrm{Na}$ questão das ações que contemplam o ensino em busca da qualidade, aqui compreendida como levar o aluno realmente a aprender e permanecer da instituição, tanto a PROEN e a DIREN são bem articuladas, pois os programas são de fato efetivados no Campus, cabe ressaltar, no entanto, que falta ainda por parte da DIREN, sair da condição de mera executora das ações da PROEN e elaborar suas ações em busca da melhoria do ensino.

Em se tratando do investimento nos docentes, quanto a qualificação, é grande, o que necessita é um olhar mais específico para as necessidades dos Campi. Talvez uma solução interessante seria a oferta de Mestrados Profissionais para os docentes.

Enfim, a pesquisa evidenciou que algumas das características e objetivos aqui tratados como: modalidades e verticalização do ensino, os arranjos produtivos locais e ações que visem o ensino de excelência, o modelo de gestão do IFPI atende, porém, a gestão de ensino precisa ter mais autonomia, para evitar que a cada semestre mude o quadro docente, devido às transferências. A PROEN deve se posicionar de forma menos centralizadora e PROEN e DIREN devem desenvolver instrumentos que possibilitem o acompanhamento e o monitoramento de suas ações. 


\section{PRODUTO TÉCNICO}

TíTULO: AVGE - Ambiente Virtual de Gestão do Ensino

\subsection{INTRODUÇÃO}

Uma instituição de ensino, para obter êxito em suas atividades, depende da ação coordenada de vários atores que atuam dentro de si, que são professores, equipe técnica, equipe pedagógica, alunos, e também de atores externos, que estão diretamente a ela ligados, como os pais. Além da ação humana direta, a instituição de ensino está vinculada a uma legislação própria que precisa atender e considerar para direcionar sua prática educativa. A instituição de ensino ainda necessita se conectar com o mundo, com as demandas de formação, lidando com as pressões econômicas, políticas e sociais. Enfim, são inúmeros os aspectos a serem considerados em todo o processo educacional formal, que, por conseguinte, necessita que as ações sejam coordenadas, planejadas, monitoradas e avaliadas, papel que cabe ao gestor institucional. O gestor, por sua vez, só age seguindo a padronização do modelo de gestão. No caso do IFPI, a gestão de ensino, embora seja um dos segmentos da gestão institucional, apresenta o seu modelo específico fundamentado nos princípios, leis e regras da instituição.

Ao estudar o modelo de gestão aplicado ao ensino no IFPI, a análise dos resultados evidenciou que a Pró-Reitoria de Ensino, unidade organizacional central, tem como um dos grandes limitadores, a falta de mecanismos para acompanhar, gerencial e avaliar as ações concernentes ao ensino em cada campus do IFPI, visto que são muitas unidades, atualmente são 20 espalhadas (17 campi e 3 campi avançados) pelo Piauí, com distâncias muitas vezes superior a $800 \mathrm{~km}$, o que inviabiliza vistas in lócuo com regularidade.

No Campus Corrente, os docentes afirmaram que seria produtivo estarem mais ligados aos docentes de outros campi, para trocar experiências, compartilhar situações de aprendizagem e fortalecer a ideia de rede, porém a distância também é uma barreira. 
Considerando as necessidades evidenciadas, que consiste na dificuldade de acompanhamento das ações de ensino nos campi, do isolamento da atividade docente ao seu próprio campus, propõe-se um produto técnico que venha atender essas demandas e subsidiar a atuação dos gestores de ensino do IFPI, podendo ser aplicado em qualquer unidade da Rede Federal de Educação Profissional Tecnológica

\subsection{DESCRIÇÃO DO PRODUTO TÉCNICO}

Produto técnico é a materialização de uma ideia. Muito embora o termo sugira finalização de um trabalho, porém, é o meio pelo qual se constrói, se aperfeiçoa ou se cria algo. Na educação, produto técnico representa uma reposta prática para uma situação desafiadora. A CAPES classifica o produto técnico por meio de cinco eixos: produção de material bibliográfico ou documental, produção passível de proteção pela propriedade intelectual, produção não passível de propriedade intelectual, produção técnica para disseminação de conhecimento e serviço técnico especializado. Nos eixos, os produtos técnicos são identificados por tipo e subtipo. 0 produto proposto AVGE - Ambiente Virtual de Gestão do Ensino - está enquadrado no eixo produção técnica para disseminação do conhecimento, identificado no tipo atividade de comunicação e difusão do conhecimento, subtipo produção de mídia.

O ambiente virtual é um espaço eletrônico, ligado à internet, que faz uso de plataformas planejadas para o desenvolvimento de determinada atividade, que permite uma interação muito grande em tempo real com várias pessoas e além do mais não se prende a um espaço físico, pode ser acessado de qualquer lugar que tenha conexão com internet e de qualquer aparelho eletrônico que conecta à rede mundial de computadores.

Os IFs têm na sua concepção o alinhamento de suas práticas ao aspecto tecnológico e também tem aptidão através do seu quadro de servidores, dos cursos ofertados e das pesquisas que desenvolvem. Por isso, a ideia é ligar um conhecimento institucional à sua necessidade, para isso tem-se o AVGE.- Ambiente Virtual de Gestão do Ensino.

O Ambiente Virtual de Gestão do Ensino consiste em plataforma on-line, com espaços de participação destinados a equipe de ensino da PROEN e DIREN e 
de docentes e alunos, os programas e projetos e todo o planejamento da PROEN e DIREN serão expostos, bem como todas as metas relacionadas ao ensino do IFPI, que foram estabelecidas pelo Termo de Metas e Compromisso. Haverá campos, ou seja, espaços, onde os documentos institucionais ligados ao ensino, estarão dispostos. O ambiente também será destinado para a capacitação do gestor de ensino nos fundamentos da gestação da pública, espaços de comunicação entre docentes-docentes (mesmo campus ou de campus diferente) docentes-alunos, docentes-gestores, gestores-alunos, gestores- gestores, alunos-alunos, além de um espaço para expor conquistas, avanços no ensino e sugestões.

O AVGE tem como objetivos:

1) Auxiliar a PROEN E DIREN, no monitoramento das ações e projetos de ensino em tempo real;

2) Facilitar a comunicação e a interação com todos os membros da equipe gestora, tanto a nível de estado, como de Campus;

3) Armazenar dados sobre carga-horária e formação docente;

4) Capacitar os gestores de ensino nos fundamentos da gestão pública;

5) Possibilitar os docentes de acompanhar todas ações de ensino e alimentar as informações no dia-a-dia;

6) Promover interação entre docentes de campi diferentes;

7) Propiciar a participação de alunos, com espaço reservado para suas opiniões e críticas sobre o planejamento de ensino executado pela PROEN;

8) Oportunizar à equipe gestora de reflexão sobre suas ações, planejandoas ou reforçando a sua utilidade.

\subsubsection{Aspectos técnicos}

AVGE é um ambiente virtual que utilizará uma plataforma e-learning, que significa um, 
síncronos e assíncronos, que dão suporte ao processo de aprendizagem, permitindo seu planejamento, implementação e avaliação (WIKIPÉDIA, 2015).

A plataforma pode ser uma já utilizada pelo IFPI, como exemplo a plataforma Moodle, que permite a extensão com a instalação e o desenvolvimento de novas funcionalidades. Os recursos que serão inseridos na plataforma, e-learning, para montar o ambiente virtual de gestão do ensino. - AVGE. - referem-se às atividades definidas para o acompanhamento e monitoramento da gestão de ensino, especificadas em:

Ficheiros: Campo que será utilizado para incluir documentos institucionais com destaque para as questões do ensino, os textos serão em formato PDF. Na Figura 3, o layout do Ficheiro, no ambiente virtual.

\section{Figura 3 - Layout do Ficheiro}

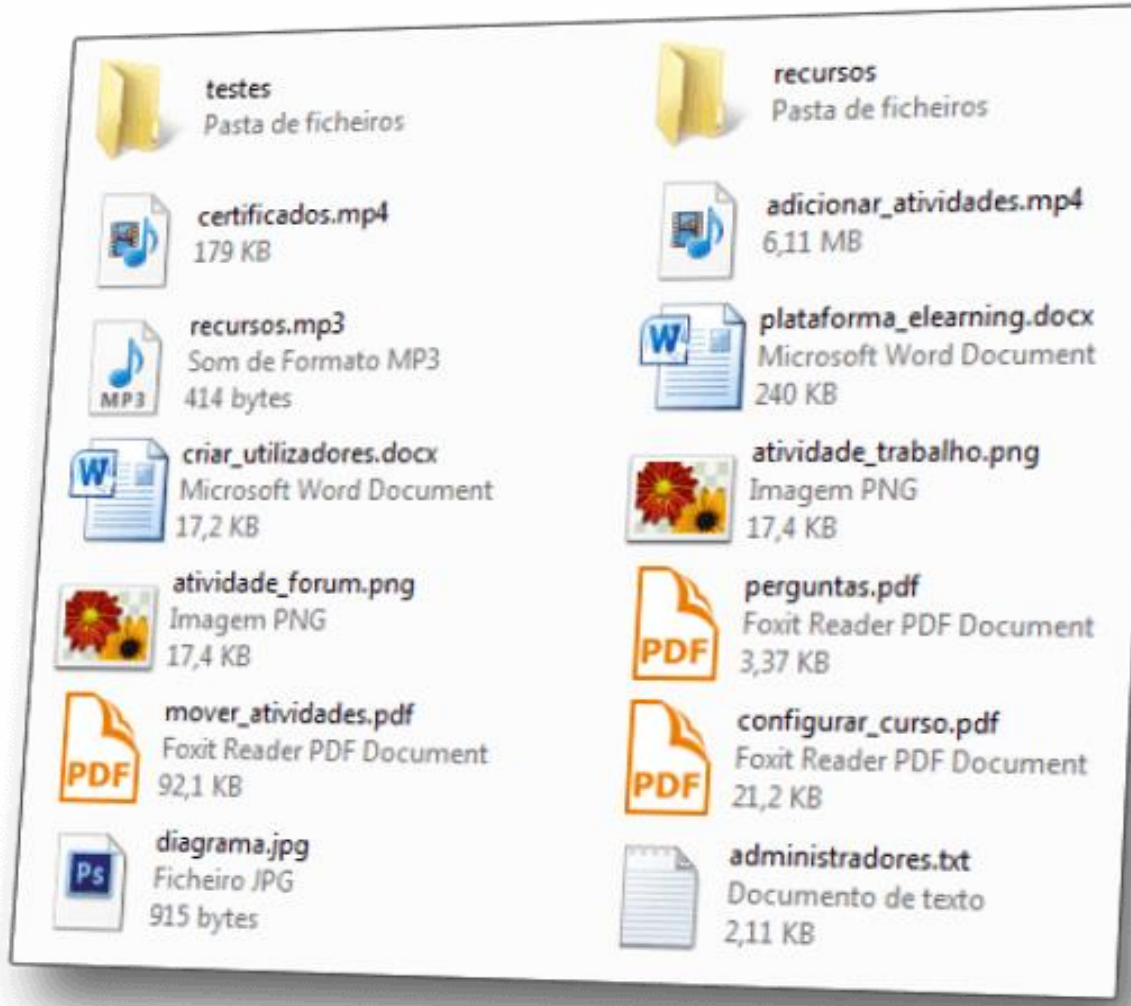

Fonte: Site - http://www.sfm.pt/e-learning/plataforma-elearning 
Página em $\mathrm{HTML}^{9}$ : Espaço onde será incluído o curso de capacitação dos gestores de ensino. O curso de capacitação, com ênfase na administração pública, tem como objetivo preparar os gestores com os fundamentos da gestão pública, proporcionando informações que subsidiam o processo de gerenciamento. A gestão educacional ainda é desenvolvida de forma amadora, haja vista que os gestores não são preparados para à função, pois muitas vezes não tem nenhuma formação na área, e as escolhas ou indicações se fundamentam nas experiências adquiridas na vivência da realidade escolar, mas atualmente a gestão no campo da escola tem exigido uma atenção especial.

A gestão no contexto educacional tem assumido um papel protagonista, devido à influência do novo modelo de gestão pública gerencial, que tem enfatizado a qualidade considerando a eficiência e a eficácia institucional, contempladas por meio do alcance de metas, que exige um planejamento sistematizado. Devido as exigências no campo da gestão escolar, aqui tratada como, gestão de ensino e é inevitável não pensar na formação e qualificação dos gestores.

\begin{abstract}
Não se pode esperar mais que os dirigentes escolares aprendam em serviço, pelo ensaio e erro, sobre como resolver conflitos e atuar convenientemente em situações de tensão, como desenvolver trabalho em equipe, como monitorar resultados, como planejar e implementar o projeto político pedagógico da escola, como promover a integração escola-comunidade, como criar novas alternativas de gestão, como realizar negociações, como mobilizar e manter mobilizados atores na realização das ações educacionais, como manter um processo de comunicação e diálogo abertos, como estabelecer unidade na diversidade, como planejar e coordenar reuniões eficazes, como articular interesses diferentes, etc (LUCK, 2000,p.29).
\end{abstract}

Os gestores são desafiados a serem profissionais qualificados, com formação especifica, pois, o trabalho de gestão exige diversas habilidades e competências, fazendo repensar as formas de seleção e escolha daqueles que irão dirigir as ações da escola. No caso do IFPI, a gestão do ensino é desenvolvida por servidores efetivos. Para o cargo de Pró-Reitor, é feita uma indicação pelo Reitor, ou seja, não há uma seleção ou processo de escolha. Já no caso da Direção de Ensino, quando o Campus tem menos de 5 anos de funcionamento, é feita a indicação pelo Reitor ou a critério do mesmo estabelece-se a consulta pública para ratificar a

\footnotetext{
${ }^{9}$ HTML (abreviação para a expressão inglesa HyperText Markup Language, que significa Linguagem de Marcação de Hipertexto) é uma linguagem de marcação utilizada na construção de páginas na Web. Fonte: Wikipédia, a enciclopédia livre.
} 
indicação. Para escolha dos gestores de ensino, não há nenhuma referência na legislação, ao contrário de Reitor e Diretor do Campus, caso em que ambos, por exigência da Lei 11892/2008 devem ter dois anos de experiência em gestão, serem doutores ou estarem no último nível da carreira ou terem feito curso na área de gestão por alguma escola de governo. Não faz nenhuma deferência sobre formação inicial ou continuada, podendo qualquer servidor, com exceção dos técnicos administrativos, cujo o concurso tenha sido para o nível médio ou fundamental.

Pela especificidade do processo de escolha dos gestores de ensino, 0 curso on-line poderá ser uma ferramenta importante na consolidação da qualidade, subsidiando as tomadas decisões e as estratégias de ação. O curso fará parte do ambiente virtual de gestão, a matriz curricular e os aspectos os pedagógicos, serão definidos por uma equipe multicampi, com membros que tenham relação com a temática. A Figura 4 traz uma visão de como será a organização do curso.

\section{Figura 4 - Layout do Ambiente do curso}

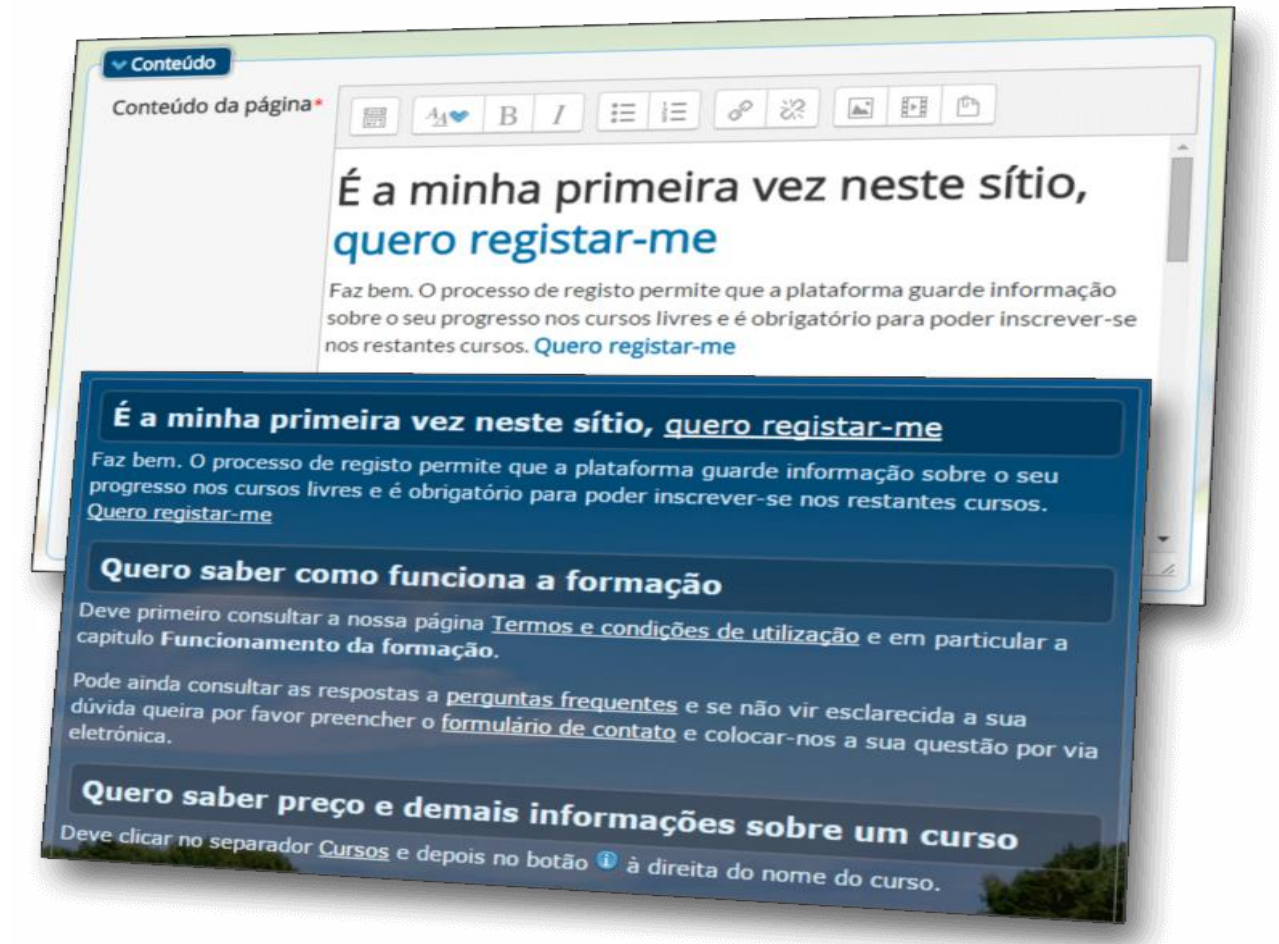

Fonte: Site - http://www.sfm.pt/e-learning/plataforma-elearning

Feedback: "É uma ferramenta essencial para avaliar a satisfação dos" usuários "e obter opiniões que poderão melhorar as ações" expostas online. (SFM SISTEMA DE FORMAÇÃO MULTIMÍDIA, 2015). Nesse campo as ações e programas 
da PROEN serão detalhados e relacionados às metas do Termo de Metas e Compromissos, para que diretores de ensino, docentes e alunos possam expor sua opinião e apresentar um detalhamento de como o programa ou ação está realmente acontecendo. A Figura 5 faz a exposição visual do ambiente, que será por meio de questionários e onde será possível um resumo das opiniões, gerando gráficos, que podem ser utilizados nas avalições e planejamento da gestão de ensino.

\section{Figura 5 - Layout do Ambiente do Feedback}

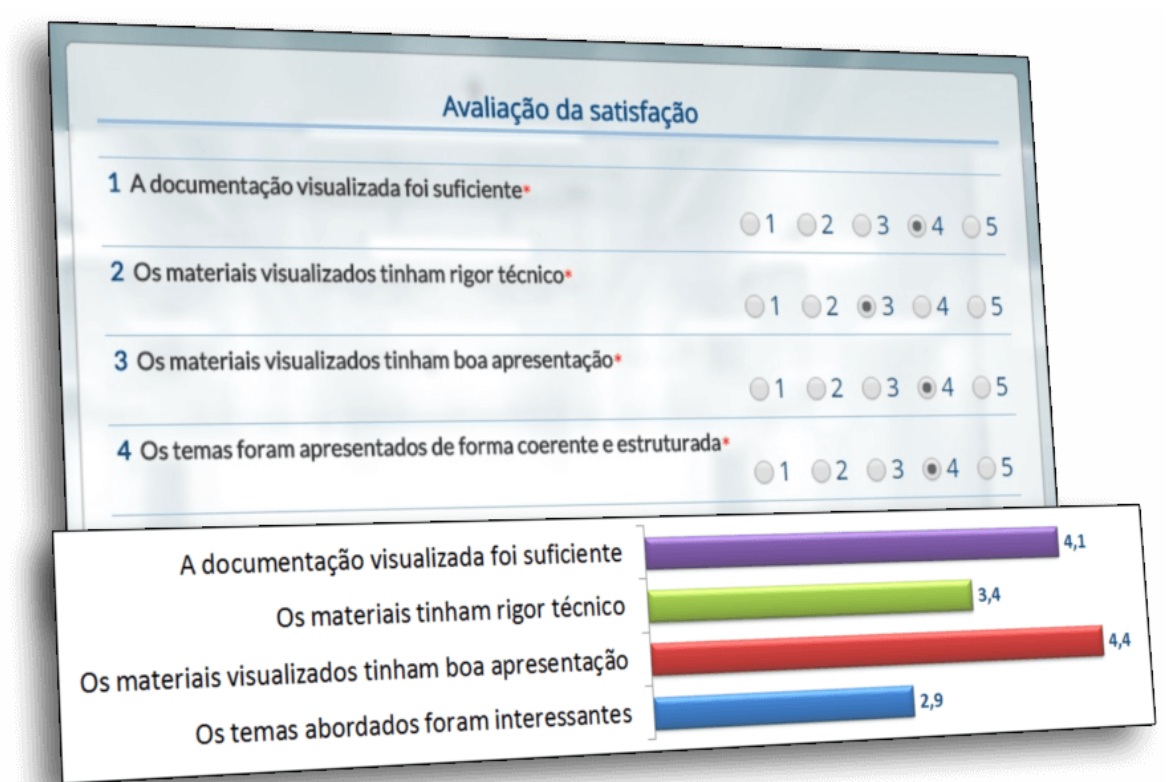

Fonte: Site - $\underline{\text { http://www.sfm.pt/e-learning/plataforma-elearning }}$

Fórum: Espaço para discutir, compartilhar experiências, sugerir atividades, enfim facilitar a comunicação entre os docentes-docentes (mesmo campus ou de campus diferente) docentes-alunos, docentes-gestores, gestores-alunos, gestores- gestores, alunos-alunos, além de um espaço para expor conquistas e avanços no ensino, além de sugestões.

As discussões nos fóruns não serão aleatórias, mas cada segmento poderá propor uma discussão a partir de uma situação vivenciada e, por um determinado período, todos que entrarem no fórum irão discutir aquele assunto já levantado. Nos ambientes virtuais comuns, os fóruns geralmente são usados para tirar dúvidas, mas na proposta do AVGE, será um espaço de desabafo mesmo, sugestões, onde os professores podem se relacionar com todos os atores internos do processo ensino aprendizagem 
Na Figura 6, pode-se observar a representação do ambiente do fórum.

\section{Figura 6 - Layout do Fórum}

\section{Fórum de dívidas}

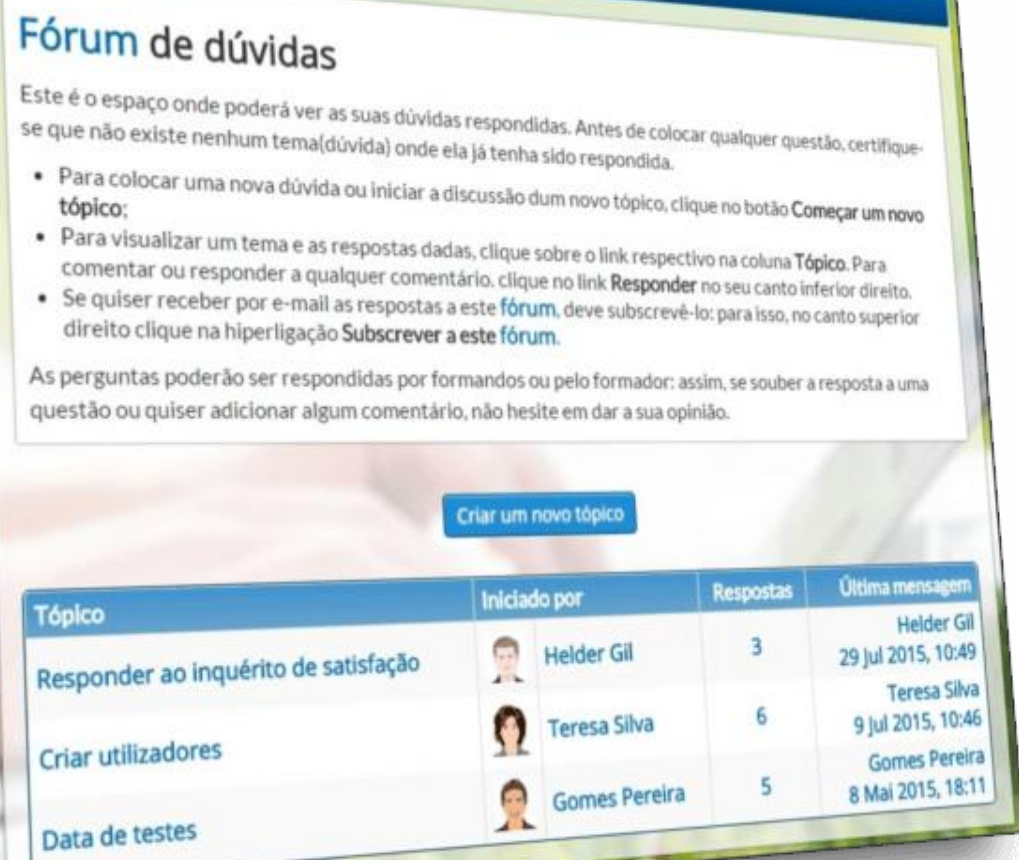

Fonte: Site - http://www.sfm.pt/e-learning/plataforma-elearning

\subsubsection{Procedimentos de uso}

Os usuários do AVGE, que são todos os membros da equipe da PROEN e DIREN, docentes e alunos serão cadastrados criando login e senha para acessar esta plataforma virtual. Nem todos os usuários terão acesso a todos os campos do ambiente virtual. Por exemplo, o curso de capacitação será destinado somente a PróReitora de Ensino e Diretora de Ensino, além de outros. Cada usuário terá uma obrigatoriedade de acessar o ambiente de tempos em tempos, variando de tempo de acordo a função, caso contrário será emitido sinais de alerta para os celulares e ou email eletrônico. 


\subsection{VANTAGENS DO AVGE}

É um produto técnico totalmente viável, pois não há um investimento financeiro alto. O IFPI já dispõe de licença para a utilização da plataforma Moodle e para criar o ambiente virtual de gestão do ensino, tem-se a equipe de TI (Tecnologia da Informação), que são analistas e desenvolvedores de software, capazes de estruturar, organizar e implantar o AVGE no plataforma e-learning. Outra vantagem é que não necessita de infraestrutura, espaço físico especifico, já que computadores com acesso à internet todos os campi tem. Por ser algo ligado à internet, pode representar um atrativo diferenciado, facilitando à participação de todos os entes envolvidos.

Enfim, além das vantagens na ordem financeira, outro aspecto positivo é proporcionar aos gestores de ensino a possibilidade de gerenciamento das ações. É um produto técnico que se relaciona com o tipo de gestão gerencial, modelo que tem inspirado as instituições públicas. 


\section{CONSIDERAÇÕES FINAIS}

Com base no objeto de estudo, o modelo de gestão aplicado ao ensino no IFPI frente às configurações dos IFs, no contexto da Pró-Reitoria de Ensino e da Direção de Ensino do Campus Corrente, considerou vários pontos analisados na pesquisa, como sendo inerentes à gestão do ensino. Os pontos fazem referência à política pública de criação dos IFs, à gestão pública e sua influência na gestão de ensino dos IFs, concepção de modelo, o modelo de gestão similar ao das universidades públicas federais, a gestão de ensino no Campus, as especificidades dos institutos, no tocante a verticalização, os arranjos produtivos locais, o investimento nos docentes, a importância da avaliação externa, a comunicação e o acompanhamento das ações.

$\mathrm{Na}$ primeira década dos anos 2000, o Brasil passou por um desenvolvimento em todas as áreas econômica, política e social, incluído a educação. Com o cenário favorável ao emprego, a demanda por mão de obra qualificada era quase um imperativo. Neste sentido, foi preciso investir mais na educação profissional, que houvera sido negligenciada nos últimos anos. Como resposta as demandas, o governo Lula (2003-2010) instituiu a política pública de expansão da Rede Federal de Educação Profissional Tecnológica. Como fruto dessa política pública, surgiram os IFs, com o incremento da Lei $\mathrm{n} \cong 11892$ de 2008, a qual estabeleceu entres outras coisas as configurações dos Institutos, no tocante as características, os objetivos e também definiu o novo modelo de gestão da instituição.

Pode-se afirmar que a expansão dos IFs foi uma política pública adotada não considerando os anseios das comunidades, mas sim à exigência do mercado, com interesses financeiros no desenvolvimento das regiões. Independente dos motivos que levaram à expansão da Rede, foi algo que produziu um efeito positivo, do ponto de vista de propiciar às cidadezinhas pequenas e pobres do interior do Nordeste, por exemplo, uma intervenção federal, por meio dos IFs, buscando o desenvolvimento local por meio da educação para o trabalho. Os IFs propiciam um diálogo com as comunidades locais para ofertar cursos que façam sentido para a região levando em consideração o seu potencial produtivo, além de buscar respeitar todas as especificidades locais no sentido da estruturação dos cursos. 
Além de buscar adequar-se à comunidade na qual está inserido, os IFs introduzem uma maneira diferente de gestão educacional. Cada Instituto Federal é parte de uma rede nacional de educação profissional e se subdivide internamente em várias unidades, denominadas de Campus. Para atender essas especificidades, temse uma gestão central, denominada de Reitoria, que é composta pelo reitor e as próreitorias, assemelhando-se com o modelo de gestão universitário. Nos Campi, a gestão é dividida em geral, administrativa e de ensino. A nova gestão dos IFs já surge dentro das novas concepções de gestão pública gerencial, que visa superar o modelo burocrático de administração. Na gestão pública gerencial, uma das características é a diminuição dos níveis hierárquicos, voltar as ações para servir bem os cidadãos, o zelo pela eficiência e eficácia das ações, enfim, a busca para atender os interesses coletivos. Para ter uma visão mesmo que superficial da nova gestão pública e como se deu esse processo, o diálogo com Bresser (2006) e Junquilho (2012) foi fundamental para criar possibilidades de comparação entre o modelo de gestão de ensino do IFPI e o novo modelo gerencial de administração.

A primeira consideração que a pesquisa evidenciou em relação ao modelo de gestão de ensino é que apresenta alguns princípios da gestão gerencial, no que tange as distribuições das funções e a existência de colegiados com representações de vários seguimentos institucionais. Porém, no geral o modelo é burocrático, o que é claramente observado nos documentos institucionais, como Regimento Interno, Organização Didática e a Resolução 011/ 2014 do Conselho Superior, a qual define a Estrutura Organizacional do IFPI, instituindo-a com muitos níveis hierárquicos, com muitas funções gratificadas, tornando uma estrutura organizacional complexa, contribuindo para o aumento da burocracia e dificultando a comunicação interna. Um aspecto que foi evidenciado na observação não participante é que as funções gratificadas são preenchidas por servidores sem que o critério principal seja a qualificação técnica específica, uma vez que são de livre nomeação e exoneração do Reitor. Não existe um procedimento técnico ou normatização para definir a ocupação das vagas.

Cabe ressaltar que a estrutura organizacional não define por completo o modelo de gestão. É necessário considerar as atribuições de cada cargo, a definição e a sistematização das ações e há de se considerar também as relações existentes entre os cargos e funções. Ao considerar esse aspecto do modelo em si, percebeu-se que as funções não se fecham nos cargos e que muitos ocupantes de cargos 
negligenciam algumas ações ou extrapolam as suas funções e assumem responsabilidades de outros. Nesse sentido, o modelo de gestão aplicado ao ensino poderia ser mais eficiente se as atribuições não estivessem arroladas numa folha de papel, mas que fossem definidas em conjunto no dia-a-dia de acordo com as demandas.

Uma consideração importante é que no Campus o modelo de gestão se torna bem diferenciado, principalmente no ensino, onde tem uma estrutura de pessoal, formada por várias coordenações voltadas só para atender ás necessidades do processo ensino, ou seja atentando para o que ocorre na sala de aula mesmo. A figura do Diretor de Ensino é uma peculiaridade, pois é um gestor que não atua diretamente nas questões administrativas. Sua ocupação é tornar o ensino eficaz e eficiente, ou seja, cuidar do acesso e permanência com êxito dos alunos, zelando pelos processos avaliativos, de acompanhamento dos alunos com rendimento escolar ruim, buscando soluções viáveis para a recuperação dos alunos, criando estratégias para melhorar os índices de evasão e repetência em todos os níveis e modalidades. Pelos dados levantados junto aos professores, coordenadores e até mesmo a gestora de ensino do Campus Corrente, a DIREN não desempenha seu papel na totalidade, porque as demandas da PROEN são constantes no sentido de fornecer informações, de participar de comissões para reformulação de documentos institucionais, visto que é comum à Direção de Ensino fazer parte de quase, se não todas, as comissões de reformulação e elaboração de projetos. Ao que parece é muito trabalho desenvolvido que não se traduz na prática em intervenções direta no processo de ensinoaprendizagem.

A Pró-Reitoria de Ensino faz articulação com as direções de ensino de todo IFPI, também implanta projetos, programas e tenta controlar as ações. A Direção de Ensino fica na ponta onde são materializados todos os planejamentos do ensino, é a primeira que sofre os impactos das decisões superiores. Uma decisão que a Direção de Ensino não tem nenhuma participação, mas que sofre diretamente seus efeitos é a remoção e redistribuição de professores e técnicos administrativos ligados ao ensino. Nas colocações da própria Diretora de Ensino

...nosso caso chegou acontecer $70 \%$ de remoção do quadro o que não foi fácil, foi bastante desafiador e isso tem prejudicado as ações porque você não consegue fechar um trabalho, uma metodologia, quando de repente já se 
muda todo o pessoal e chega um pessoal novo sem experiência que não conhecer a metodologia dos IFs e vai num reaprender e isso vem atrasando algumas conquistas, eu diria assim.

Imaginar que em um único ano, uma turma contou mais de quatro professores de língua portuguesa, é um fato que no mínimo compromete a aprendizagem, mesmo que sejam professores bem qualificados, mas cada profissional tem seu jeito especifico de trabalhar, o que exige dos alunos, uma readaptação constante, a falta de continuidade é prejudicial para a aprendizagem. Uma conquista recente é que o professor só é removido, quando chega outro para ocupar o lugar. De certa forma, os alunos não ficam com déficit de aulas. Segundo relatos da Direção de Ensino, em outras épocas os professores eram removidos e não havia nenhuma expectativa de outro para suprir a vaga ociosa.

Será que se o Campus realmente fosse autônomo para definir seu quadro de docentes, estaria vivenciando essa situação de constantes mudanças em seus quadros de servidores? Se o Campus fosse autônomo para gerir os recursos destinados aos programas de ensino, para definir sua oferta de cursos considerando sim os arranjos produtivos locais, mais indo além, considerando os anseios da comunidade local, o IFPI Campus Corrente teria mais êxito em suas atividades de ensino? Autonomia é um grande desafio para a gestão geral e de ensino do IFPI.

Aliados à autonomia existem outros desafios institucionais para PróReitoria de Ensino e a Direção de Ensino no Campus Corrente, que são a verticalização do ensino, oferta de ensino em várias modalidades, a própria relação PROEN - DIREN que necessita ser otimizada, no sentido de garantir mais celeridade das ações e uma comunicação mais eficiente e o acompanhamento e monitoramento das ações de ensino.

Por fim, mesmo com tantas fragilidades no modelo de gestão do ensino no IFPI, pelas avaliações externas, que a instituição é submetida, testificam que há um rendimento satisfatório, percebe-se então que o modelo de gestão aplicado ao ensino funciona no IFPI e atende algumas das especificidades dos IFs, porém necessita ser aprimorado, mas talvez o IFPI, ainda esteja passando por um período de adaptação ao novo modelo, uma vez que foi instituindo em 2008, em uma instituição que tinha uma outra forma de atuar, baseada em princípios cristalizados ao longo de décadas. 


\section{REFERÊNCIAS BIBLIOGRÁFICAS}

ÁBACO. In: Dicionário Michaelis. Disponível em: <www.uol.com.br/michaelis>. Acesso em: 20 agosto. 2015.

ALMEIDA NETO, Antônio Clodoaldo. Modelagens sobre gestão organizacional em uma perspectiva multidisciplinar e sistêmica: proposições para a Rede Federal de Educação Profissional, Científica e Tecnológica - RFEPCT. Tese (Doutorado Multi-institucional e Multidisciplinar em Difusão do Conhecimento) - Programa de PósGraduação, Universidade Federal da Bahia, Salvador, 2013.

ARAÚJO, Suêldes de e CASTRO Alda Maria Duarte. Gestão educativa gerencial: superação do modelo burocrático? Ensaio: aval. pol. públ. Educ., Rio de Janeiro, v. 19, n. 70, p. 81-106, jan./mar. 2011.

BARDIN, L. Análise de conteúdo. 70 ed. São Paulo: Almedina Brasil, 2011.

BAUER, M. W.; GASKELL, G. Pesquisa qualitativa com texto, imagem e som: um manual prático. Petrópolis, RJ: Vozes, 2002.

BIASI, Simoni Vilant. O professor e qualidade de ensino: uma análise a partir dos resultados do Saeb na escola pública do Paraná. Dissertação de Mestrado. NUPE - Núcleo de Políticas, Gestão e Financiamento da Educação da Universidade Federal do Paraná. UFPR, 2009.

BRASIL. Ministério da Educação: Centenário da rede federal de educação profissional e tecnológica. [Documento eletrônico]. Disponível: Acesso em: 21 abr. 2015.

BRASIL. Tribunal de Contas da União. Manual para produção e análise de indicadores da rede federal de educação profissional, científica e tecnológica EPCT. 2012.

BRASIL. Ministério do Planejamento, Orçamento e Gestão. Instituto Brasileiro de Geografia e Estatística. Censo 2010. Disponível em: www.censo2010.ibge.gov.br/sinopse/index.php?uf=22\&dados.... Acesso em: 12 abr. 2014.

BRASIL. Ministério da Educação. Secretária de Educação Profissional Tecnológica. Concepções e Diretrizes, SETEC 2010, p.20.

BRASIL. Lei o 11.892, de 29 de dezembro de 2008. Institui a Rede Federal de Educação Profissional, Científica e Tecnológica, cria os Institutos Federais de Educação Ciências e Tecnologia e dá outras providências. http://www.planalto.gov.br > Acesso em: 20 out. 2014.

BRASIL. Lei $n^{\circ} 11.195$, de 18 de novembro de 2005. Dá nova redação ao $\$ 50$ do art. 3 o da Lei no.948, 08 de dezembro de 1994. http://www.planalto.gov.br > Acesso em: 20 out. 2015. 
BRASIL. Decreto $n^{\circ} 5.224$, de $1^{\circ}$ de outubro de 2004. Dispõe sobre a organização dos Centros Federais de Educação Tecnológica e dá outras providências. [Documento eletrônico]. Disponível em: Acesso em: 05 jul. 2014.

BRASIL. Decreto $n^{\circ} 5.225$, de 1 de outubro de 2004. Altera dispositivos do Decreto no 3.860, de 9 de julho de 2001, que dispõe sobre a organização do ensino superior e a avaliação de cursos e instituições, e dá outras providências. [Documento eletrônico]. Disponível em: Acesso em: 05 jul. 2014.

BRASIL. Decreto 5.154, de 23 de julho de 2004. Regulamenta o § 2 o do art. 36 e os arts. 39 a 41 da Lei $n=9.394$, de 20 de dezembro de 1996, que estabelece as diretrizes e bases da educação nacional, e dá outras providências. http://www.planalto.gov.br > Acesso em: 20 out. 2015.

BRASIL. Lei no. 10.861, de 14 de abril de 2004. Institui o Sistema Nacional de Avaliação da Educação Superior - SINAES e dá outras providências. Disponível em: <http://www.planalto.gov.br >. Acesso em: 19 set. 2015.

BRASIL. Constituição da República Federativa do Brasil. 10.ed. Brasília, DF: Câmara dos Deputados, Coordenação de Publicações, 1998.

BRASIL, Lei 9394, de 20 de dezembro de 1996. Estabelece Diretrizes e Bases para a educação nacional. Diário Oficial da República Federativa do Brasil, Brasília, DF, 23 dez. 1996.

BRASIL. Lei $n^{\circ} 8.948$, de 8 de dezembro de 1994. Dispõe sobre a instituição do Sistema Nacional de Educação Tecnológica e dá outras providências. http://www.planalto.gov.br > Acesso em: 20 out. 2015.

BRASIL. Lei $n^{\circ} 6.545$, de 30 de junho de 1978. Dispõe sobre a transformação das Escolas Técnicas Federais de Minas Gerais, do Paraná e Celso Suckow da Fonseca em Centros Federais de Educação Tecnológica e dá outras providências. http://www.planalto.gov.br > Acesso em: 20 out. 2015.

BRASIL. Lei no 5.540 , de 28 de novembro de 1968. Fixa normas de organização e funcionamento do ensino superior e sua articulação com a escola média, e dá outras providências. Disponível em: < http://www.planalto.gov.br > Acesso em: 19 set. 2015.

BRASIL. Decreto - lei o 4.127, de 25 de fevereiro de 1942. Estabelece as bases de organização da rede federal de estabelecimentos de ensino industrial. http://www.planalto.gov.br > Acesso em: 20 out. 2015.

BRASIL. Lei n. 378 de 13 de janeiro de 1937. Dá nova, organização ao ministério da educação e saúde pública. <http://www.planalto.gov.br > Acesso em: 10 out. 2015.

BRASIL. Decreto o 7.566, de 23 de setembro de 1909.Créa nas capitaes dos Estados da Escolas de Aprendizes Artífices, para o ensino profissional primario e gratuito. <http://www.planalto.gov.br > Acesso em: 19 set. 2015. 
BNDES, Banco Nacional de Desenvolvimento Econômico e Social. BNDES e Banco do Brasil vão apoiar pequenas empresas integrantes de Arranjos Produtivos Locais. Disponível em: <http://wwwbndes.gov.br/notícias/not620asp> Acesso em: 16 de outubro de 2014.

BRESSER-PEREIRA, Luiz Carlos (1996). Da Administração Pública Burocrática à Gerencial. Revista do Serviço Público, 47(1) janeiro-abril. Disponível em $<$ http://academico.direitorio.fgv.br/ccmw/images/1/1d/Bresser.pdf> Acesso em 10 de julho de 2015.

. Da administração pública burocrática à gerencial. Revista do Serviço Público, 47(1) janeiro-abril 1996. Trabalho apresentado ao seminário sobre Reforma do Estado na América Latina organizado pelo Ministério da Administração Federal e Reforma do Estado e patrocinado pelo Banco Interamericano de Desenvolvimento. Brasília, maio de 1996.

Gestão do Setor público: estratégia e estrutura para um novo Estado, em Reforma do Estado e administração pública gerencial, organizadores. SPINK, Peter, 7ª̣. edição, Rio de Janeiro, Editora Fundação Getúlio Vargas, 2006, 316 p.

Reflexões sobre a reforma gerencial brasileira de 1995. Revista do Serviço Público. Ano 50 Número 4 Out-Dez, 1999.

CAMPOS, Vicente Falconi. O Verdadeiro Poder - Práticas de Gestão que Conduzem a Resultados Revolucionários. INDG, 2009.

CARDOSO, Marcos Milani. Análise de política públicas: conceitos básicos. In: RUA, M . G.; CARVALHO, M. (Orgs.). O estudo da política: tópicos Selecionados. Brasília: Paralelo 15, 2010.

Ideação à inovação disruptiva: um estudo de caso sobre seus condicionantes. São Carlos. UFSCar. 2004.

CARVALHO, Olgamir Francisco de. Educação e Formação profissional - Trabalho e tempo livre. Brasília: Plano Editora, 2003.

CASTRO, A. M. D. A. Accountability: uma nova estratégia de controle da gestão escolar. In: CONFERÊNCIA INTERNACIONAL EDUCAÇÃO, GLOBALIZAÇÃO E CIDADANIA, 2006. Novas perspectivas da sociologia da educação: trabalhos apresentados. João Pessoa: UFPB, 2006.

CHRISTOPHE, Micheline. A legislação sobre a educação tecnológica no quadro da educação profissional brasileira. IETS: Rio de Janeiro. [on-line]. 2005. CUNHA, Célio da. et.al. Política Governamental na América Latina: lições aprendidas e desafios. Campinas - SP: Autores Associados, 2011.

DEMO, Pedro. CUIDADO METODOLÓGICO: signo crucial da qualidade. Sociedade e Estado, Brasília, v. 17, n. 2, p. 349-373, jul./dez. 2002. 
DOURADO, Luiz Fernandes. A Escolha de Dirigentes Escolares: políticas e gestão da educação no Brasil. In: FERREIRA, Naura Syria Carapeto. Gestão Democrática da Educação: atuais tendências novos desafios. $2^{\underline{a}}$ ed. São Paulo: Cortez, 2000.

DOWBOR, Ladislau. EDUCAÇÃO E DESENVOLVIMENTO LOCAL. Disponível em: $<$ http://dowbor.org > Acesso em 11 de maio de 2014.

DUARTE, Rosália. Pesquisa qualitativa: reflexões sobre o trabalho de campo. In Cadernos de Pesquisa Fundação Carlos Chagas. Rio de Janeiro: FCC, n.115, 2002.

ELPO, Mirian E. H. Collares. Avaliação da Gestão Universitária - Velhos Problemas e Novas Perspectivas. 2004.

FRANCISCO, Wagner De Cerqueria E. "Taylorismo e Fordismo"; Brasil Escola. Disponível em http://www.brasilescola.com/geografia/taylorismo-fordismo.htm>. Acesso em 10 de setembro de 2015.

FERNANDES, Francisco das Chagas de Mariz. Novo design para a rede federal de educação tecnológica. Holos, Ano 24, Vol. 3 56, 2008.

FERREIRA, Victor Cláudio Paradela et al. Modelos de gestão. Série Gestão de Pessoas . Rio de Janeiro: FGV, 2005.

FRANÇA, Júnia Lessa. et. al. Manual para normatização de publicações técnicoscientíficas.ed.8‥ Belo Horizonte. Editora Belo Horizonte. UFMG, 2009.

GARCIA, Ana Lúcia. GESTÃO DA ESCOLA, QUALIDADE DO ENSINO E AVALIAÇÃO EXTERNA: Desafios na escola. Dissertação (Mestrado em Educação), Universidade Estadual Paulista Júlio de Mesquita Filho. Marília, 2010.

GARCIA, Maurício. Estruturas organizacionais em instituições privadas de ensino superior, 2005. Disponível em: <http://buiatria.com.br/mgPdf/2005 > Acesso em 12 de agosto de 2015.

GIL, Antônio Carlos. Métodos e técnicas de pesquisa social. 6 ed. São Paulo: Atlas, 2014.

GODOY, Arilda S. Introdução à pesquisa qualitativa e suas possibilidades, In Revista de Administração de Empresas, v.35, n.2, Mar./Abr. 1995a, p. 57 - 63. Pdf <http://www.cidades.ibge.gov.br/cartograma/mapa>. Acesso em 27/09/2015.

GOLDENBERG, Mirian. A arte de pesquisar. Rio de Janeiro: Record,1999.

HEIDEMANN, Francisco G e SALM, José Francisco. (orgs). Políticas públicas e desenvolvimento: bases epistemológicas e modelos de análise. Brasília: Editora Universidade de Brasília, 3ª edição, 2014. 
HENGEMÜHLE, Adelar. Gestão de ensino e práticas pedagógicas. Petrópolis RG: Vozes, $7^{\mathrm{a}} \mathrm{Ed}, 2004$.

HOFLING, Eloísa de Mattos. Estado e políticas (públicas) sociais. Seminário. Cadernos Cedes, Campinas, ano XXI, n. 55, novembro, 2001. Disponível em $<$ http://www.scielo.br/pdf/ccedes/v21n55/5539.pdf > Acesso em 10 de julho de 2015.

IERVOLINO, SA.; PELICIONI, MCF. A utilização do grupo focal como metodologia qualitativa na promoção da saúde. Rev Esc Enf USP, v. 35, n.2, p.115-21, jun, 2001.

IFPI. Organização didática. 2010. Disponível em: < www.ifpi.edu.br > Acesso em: 20 out. 2015.

IFPI. Portaria no 1.203, IFPI. Boletim de Serviço Edição Extra no 04, 2011.

IFPI. Resolução 20 / 2011 de 06 de dezembro de 2011. Disponível em:

< www.ifpi.edu.br > Acesso em: 20 out. 2015.

JANUZZI, Paulo de Martino. Indicadores de Gestão de Políticas Públicas. 2005. Disponível

http://www.abep.nepo.unicamp.br/site eventos abep/PDF/ABEP2004 296.pdf>

Acesso em 20 maio de 2014.

, Indicadores Sintéticos no processo de formulação e avaliação

de Políticas Públicas: Limites e Legitimidades. XIV Encontro de Estudos Populacionais. Caxambú - MG - Brasil. 2004.

JUNQUILHO, Gelson Silva. Teorias da administração pública / Gelson Silva Junquilho. - 2. ed. Reimp. - Florianópolis: Departamento de Ciências da Administração / UFSC; [Brasília]: CAPES: UAB, 2012.

JUNQUILHO, Gelson Silva. Ação gerencial na Administração Pública: a re/produção de "raízes" brasileiras. 2000. 334 f. Tese (Doutorado em Administração) - Universidade Federal de Minas Gerais - Faculdade de Ciências Econômicas, Belo Horizonte - MG, 2000.

KERLINGER, F. N. Metodologia da pesquisa em ciências sociais: um tratamento conceitual. São Paulo: EPU/EDUSP, 1980.

LEITÃO, Sérgio Proença. A questão organizacional na universidade: as contribuições de Etzioni e Rice. Revista de Administração Pública da FGV, Rio de Janeiro, v.4, n.19, p. 3-26, out./dez. 1985.

LEITE, Giancarlo de Cristo. Instituições de ensino: Implantação de um modelo de gestão baseado em diretrizes. Faculdade de Pinhais (FAPI) - Pinhais - Brasil, 2010.

LIMA FILHO, Domingos Leite. Dimensões e limites da globalização. Petrópolis, Vozes, 2005. 
LIMA FILHO, Domingos Leite; QUELUZ, Gilson Leandro. A Tecnologia e a Educação Tecnológica: elementos para uma sistematização conceitual. Revista Educação tecnológica. Belo Horizonte. V.10. n-1, p 18 - 28, jan-jun/2005. Disponível em: < www.seer.dppg.cefetmg.br > acesso em 03 de setembro de 2015.

LOPES, Luiz Antônio Coelho. Et. Al. Estruturas Administrativas Das Universidades Brasileiras. VIII SEMEAD Seminários em Administração FEA USP, agosto de 2005.

LOPES, Coelho; BERNARDES, Ribeiro. Estruturas Administrativas das Universidades Brasileiras. Disponível em: <www.fran@finep.gov.br> Acesso em 20 abril, 2014.

LOTTA, Gabriela. Agentes de Implementação: um olhar para as políticas públicas. In: ABCP - Associação Brasileira de Ciência Política, Campinas. ABCP, 2008. Disponível em <http://gabrielaslotta.files.wordpress.com/2012/09/artigoabcp.pdf > Acesso em 20 maio de 2014.

LÜCK, Heloísa. Perspectivas da Gestão Escolar e Implicações quanto à Formação de seus Gestores. Em Aberto, Brasília, v. 17, n. 72, p. 11-33, fev./jun. 2000.

MATTOS, Carmen Lúcia Guimarães de. A abordagem etnográfica na investigação científica. UERJ, 2001.

MAURICE, Tardif. Saberes Docentes e Formação Profissional. Petrópolis: Vozes, 2011.

MENEZES, Estera Muszkat. Metodologia da Pesquisa e Elaboração de Dissertação. 3a edição Edna Lúcia da Silva. Florianópolis.2001.

MINAYO, Maria Cecília de Souza (org.). Pesquisa Social. Teoria, método e criatividade. 18 ed. Petrópolis: Vozes, 2001.

MINISTÉRIO DA EDUCAÇÃO. Expansão da Rede Federal. Disponível em. <www.mec.gov.br/setec > Acesso em: 18 de setembro de 2015.

MINTZBERG, H. Criando organizações eficazes. São Paulo: Atlas, 1995.

MORAN, José Manuel. Gestão Inovadora da Escola com Tecnologias. In: VIEIRA, A. T.; ALMEIDA, M. E. B. de; ALONSO, M. (Org.). Gestão Educacional e Tecnologia. São Paulo, Avercamp, 2003.

MOODLE. In: Wikipédia: a enciclopédia livre. Disponível em: < https://pt.wikipedia.org/wiki/Moodle> Acesso em: 8 out 2015.

MOITA, Filomena Maria Gonçalves da Silva Cordeiro; ANDRADE, Fernando Cézar Bezerra. Ensino-pesquisa-extensão: um exercício de indissociabilidade na pósgraduação. In: Revista Brasileira de Educação, v.14 n.41 maio/ago 2009, p 269-280. 
NAJAN, A. Learnin from the Literature on Policy Implementation: A Synthesis Perspective. (Working Papers). Inertnational Institute for Appli ed. Systems Analysis IIASA. A-2361 Luxwnburg. Austria. 1995.

NEVES, José Luis. Pesquisa qualitativa: características, usos e possibilidades. Caderno de pesquisas em administração, São Paulo, v. 1, nํㅜ 3, 2 Sem./1996.

OTRANTO, C. R. Criação e Implantação dos Institutos Federais de Educação, Ciência e Tecnologia - IFETs. Revista Retta. UFRRJ/PPGEA, Seropédica, RJ: EDUR, Vol. I, no 01, jan./jun. 2010, p. 89-108.

PACHECO, Eliezer. OS INSTITUTOS FEDERAIS Uma Revolução na Educação Profissional e Tecnológica. Ministério da Educação Secretaria de Educação Profissional e Tecnológica Esplanada dos Ministérios. Edifício Sede, bloco L, $4^{\circ}$ andar, 2010.

. Perspectivas da educação profissional técnico de nível médio: propostas de diretrizes curriculares. São Paulo: Moderna, 2012.

. Uma revolução na educação profissional e tecnológica. Brasília, São Paulo: Moderna, 2011.

PARO, Vitor Henrique. Gestão democrática da escola pública. 3. ed. Série: educação em ação São Paulo: Ática, 1997.

PEREIRA, Luiz Augusto Caldas. A rede federal de educação tecnológica e o desenvolvimento local.Mestrado em Planejamento Regional e Gestão de Cidades Universidade Candido Mendes- Campos dos Goytacazes, 2003.

PLATAFORMA - ELEARNING. Plataforma moodle. <http://www.sfm.pt/elearning/plataforma-elearning > Acesso em: 18 de setembro de 2015.

REVISTA NOVA ESCOLA. Uma boa aula. <http://revistaescola.abril.com.br Acesso em: 18 de setembro de 2015.

ROSENTHAL, E. A propósito da qualidade do ensino superior no Brasil: anais de dois encontros. Brasília, DF: Conselho Federal de Educação, 1982.

SÁ, Jean Magno Moura de. Gestão na educação profissional e tecnológica:

a escola agrotécnica federal de São Luiz entre 2002 e 2006 . Dissertação de Mestrado. Programa de Pós-Graduação em Educação Faculdade de Educação Universidade de Brasília, Brasília, 2009.

SBORGIA, Renata Carone. Responsabilidade Acadêmica do Gestor Educacional. Editora: Madras, 2012.

SOARES, ANA MARIA DANTAS. Graduação em desenvolvimento, agricultura e sociedade política educacional e configurações dos currículos de formação de técnicos em agropecuária, nos anos 90: regulação ou emancipação? Tese de Doutorado. Área de Concentração em Sociedade e Agricultura Seropédica, RJ, 2003. 
SOBRINHO, Jd. Avaliação institucional da educação superior: fontes externas e internas . Avaliação, Campinas, 1998.

SOBRINHO, Sidinei Cruz. GESTÃO DE ENSINO DIREÇÃO DE ENSINO IFFARROUPILHA CÂMPUS SANTA ROSA. 2014.

SOUZA. Celina. Políticas Públicas: Uma revisão da literatura. Sociologias, Porto Alegre, ano 8, no 16, jul/dez 2006, p. 20-45.

SOUZA, Eda Castro Lucas de; CASTIONI Remi. Institutos Federais: os desafios da institucionalização. Brasília: Editora Universidade de Brasília, 2012.

STALLIVIERI, Luciane. O Sistema De Ensino Superior do Brasil Características, Tendências e Perspectivas. Caxias do Sul - SC. 2006.

TARDIF, Maurice. Saberes docentes e formação profissional. $17^{a}$ edição. Petrópolis, RJ: Vozes, 2014.

TAVARES, Moacir Gubert. Evolução da Rede Federal de Educação Profissional e Tecnológica: as etapas históricas da Educação Profissional no Brasil. In: IX Seminário de Pesquisa em Educação da Região Sul ANPED SUL, 2012, Caxias do Sul. Anais eletrônicos... Caxias do Sul: UCS, 2012. Disponível em: <http://www.ucs.br/etc/conferencias/index.php/anpedsul/9anpedsul/paper/viewFile/17 7/103>. Acesso em: 29 out. 2015.

VEIGA, A Ilma Passos. (Org.). Projeto político-pedagógico da escola: Uma construção possível. 12ª edição. Campinas, SP: Papirus, 2001.

VERASZTO, Estéfano Vizconde. Tecnologia: Buscando uma definição para o conceito. Dissertação de Mestrado. Universidade Estadual de Campinas São Paulo, São Paulo, 2008.

VIANNA, Heraldo Marelim. Pesquisa em Educação: a observação. Brasília: Plano Editora, 2013.

VIEIRA, Alexandre Thomaz. et al. Gestão Educacional e Tecnologia. São Paulo: Avercamp, 2003.

VIEIRA, Euripedes Falcão. et al. Funcionalidade Burocrática nas Universidades Federais: Conflito em Tempos de Mudança. RAC, V. 8, N. 2, Abr./Jun. 2004: 181200.

VIEIRA, Euripedes; VIEIRA, Marcelo. Estrutura organizacional e gestão do desempenho nas universidades federais brasileiras. RAC, Rio de Janeiro, 37, Julho, 2003.

VIEIRA, Sebastião Gândara. Educação profissional e os APLS: uma ação efetiva na promoção do desenvolvimento regional. Disponível em 
www.universia.com.br/docente/materia.jsp?materia=9032 Disc Ed. Profissional e Tecnológica/ Prof. Dr. Paulo Gomes Lima - FAED/UFGD - 1 Sem. de 2010. 


\section{APÊNDICE A - TERMO DE CONSENTIMENTO DOS SUJEITOS I TERMO DE CONSENTIMENTO LIVRE E ESCLARECIDO}

Prezado(a) participante:

Sou estudante do curso de Pós - Graduação na Faculdade de Educação da Universidade de Brasília - UnB. Estou realizando uma pesquisa sob orientação do professor PhD. Bernardo Kipnis, cujo objetivo geral é: Analisar o modelo de gestão aplicado ao ensino do IFPI, quanto às finalidades e características dos IFs, segundo a Lei 11.892/2008.

Sua participação envolve entrevista, que será gravada em áudio, para posterior transcrição, se assim você permitir, e que tem a duração aproximada de 20 min.

A participação nesse estudo é voluntária e se você decidir não participar ou quiser desistir de continuar em qualquer momento, tem absoluta liberdade de fazê-lo.

Na publicação dos resultados desta pesquisa, sua identidade será mantida no mais rigoroso sigilo e serão omitidas todas as informações que permitam identificá-lo.

Mesmo não tendo benefícios diretos em participar, indiretamente você estará contribuindo a para a compreensão do fenômeno estudado e para a produção de conhecimento científico.

Quaisquer dúvidas relativas à pesquisa poderão ser esclarecidas pela pesquisadora, fone/ whatsapp (89) 9909-9975, ou pela entidade responsável - Comitê de Ética em Pesquisa da UnB, fone (61) 3107 - 6243.

\section{Atenciosamente,}

Joedna Lobato do Amaral Hubner Mestranda - Matrícula:13/0178667

PhD. Bernardo Kipnis Orientador

Corrente - PI, maio de 2015

\section{Consinto em participar deste estudo e declaro ter recebido uma cópia deste termo de consentimento.}




\title{
APÊNDICE B - CONVITE
}

\section{O MODELO DE GESTÃO APLICADO AO ENSINO DO IFPI, FRENTE ÀS CONFIGURAÇÕES DOS IFs.}

\author{
Prezado (a) Docente
}

Convidamos Vossa Senhoria para participar do GRUPO FOCAL- um dos instrumentos de coleta de dados da pesquisa científica do Mestrado em Políticas Públicas e Gestão da EPT - UnB, cujo objetivo principal é analisar o modelo de gestão aplicado ao ensino do IFPI, quanto às finalidades e características dos Ifs. Ocorrerá na Sala de Reuniões da Direção Geral, no dia 14 de maio de 2015 às 14:30h. Sua contribuição será útil para o enriquecimento da nossa instituição.

Obrigada!

Joedna Hubner

Mestranda 


\section{APÊNDICE C TERMO DE CONSENTIMENTO DOS SUJEITOS II}

\section{TERMO DE CONSENTIMENTO LIVRE E ESCLARECIDO}

\section{Prezado(a) participante:}

Sou estudante do curso de Mestrado em Políticas Públicas e Gestão da Educação Profissional Tecnológica na Faculdade de Educação da Universidade de Brasília - UnB. Estou realizando uma pesquisa sob orientação do professor PhD. Bernardo Kipnis, cujo objetivo geral é: Analisar o modelo de gestão aplicado ao ensino do IFPI, quanto às finalidades e características dos IFs.

Sua participação envolve um grupo focal, que será filmado e terá duração aproximada de 2 horas.

A participação nesse estudo é voluntária e se você decidir não participar ou quiser desistir de continuar em qualquer momento, tem absoluta liberdade de fazê-lo.

Na publicação dos resultados desta pesquisa, sua identidade será mantida no mais rigoroso sigilo. Serão omitidas todas as informações que permitam identificá-lo.

Mesmo não tendo benefícios diretos em participar, indiretamente você estará contribuindo a para a compreensão do fenômeno estudado e para a produção de conhecimento científico.

Quaisquer dúvidas relativas à pesquisa poderão ser esclarecidas pela pesquisadora, fone/ whatsapp (89) 9909-9975, ou pela entidade responsável - Comitê de Ética em Pesquisa da UnB, fone (61) 3107 - 6243.

Atenciosamente,

Joedna Lobato do Amaral Hubner Mestranda - Matrícula:13/0178667
PhD. Bernardo Kipnis

Orientado

Corrente - PI, maio de 2015

Consinto em participar deste estudo e declaro ter recebido uma cópia deste termo de consentimento. 


\section{APÊNDICE D - TERMO DE CONSENTIMENTO DOS SUJEITOS III}

\section{TERMO DE CONSENTIMENTO LIVRE E ESCLARECIDO}

\section{Prezado(a) participante:}

Sou estudante do curso de Pós - Graduação na Faculdade de Educação da Universidade de Brasília - UnB. Estou realizando uma pesquisa sob orientação do professor PhD. Bernardo Kipnis, cujo objetivo geral é: Analisar o modelo de gestão aplicado ao ensino do IFPI, quanto às finalidades e características dos IFs, segundo a Lei 11.892/2008.

Sua participação envolve responder um questionário aberto. A participação nesse estudo é voluntária e se você decidir não participar ou quiser desistir de continuar em qualquer momento, tem absoluta liberdade de fazê-lo.

Na publicação dos resultados desta pesquisa, sua identidade será mantida no mais rigoroso sigilo e serão omitidas todas as informações que permitam identificá-lo.

Mesmo não tendo benefícios diretos em participar, indiretamente você estará contribuindo a para a compreensão do fenômeno estudado e para a produção de conhecimento científico.

Quaisquer dúvidas relativas à pesquisa poderão ser esclarecidas pela pesquisadora, fone/ whatsapp (89) 9909-9975, ou pela entidade responsável - Comitê de Ética em Pesquisa da UnB, fone (61) 3107 - 6243.

\section{Atenciosamente,}

Joedna Lobato do Amaral Hubner Mestranda - Matrícula:13/0178667
PhD. Bernardo Kipnis

Orientador

$$
\text { Corrente - PI, maio de } 2015
$$

Consinto em participar deste estudo e declaro ter recebido uma cópia deste termo de consentimento. 


\section{APÊNDICE E - QUESTIONÁRIO ABERTO}

\section{QUESTIONÁRIO ABERTO COM OS COORDENADORES DE ENSINO}

Nome

Formação

Ingresso no IFPI

1. Qual o papel de sua coordenação?

2. Quais são os desafios da gestão do IFPI, no atendimento às diversas modalidades de ensino?

3. Como o modelo de gestão dos IFs favorece o atendimento às demandas sociais e as peculiaridades regionais?

4. A verticalização do ensino, uma das características dos IFs, constitui um problema para a gestão de ensino do IFPI?

5. Como o senhor percebe a relação da DIREN coam a PROEN?

6. Coordenação dentro da estrutura organizacional da DIREN IFPI, tem sua autonomia garantida?

7. Na sua opinião, qual o principal papel da DIREN ?

8. Na prática qual é o papel mais relevante no andamento das ações do IFPI?

9. Como é verificada a qualidade do ensino na questão da associação entre teoria e prática tendo em vista o desenvolvimento local?

10. Quais as ações desenvolvidas pela gestão de ensino, que contemplam a atuação docente em busca da qualidade do ensino no IPFI?

11. Existe alguma parceria com a Secretaria estadual de Educação?

12. Como as ações da Coordenação são monitoradas e avaliadas?

13. Na sua percepção o que falta na estrutura da DIREN, para melhor desenvolver suas atividades? 


\section{APÊNDICE F - ROTEIRO DA OBSERVAÇÃO}

\section{ROTEIRO DA OBSERVAÇÃO NÃO PARTICIPANTE}

> Observar a organização da estrutura da PROEN, na prática

> Observar com ocorre a articulação com as DIREN;

> Planejamento das ações de ensino;

> Identificar os principais programas desenvolvidos pela PROEN

$>$ Identificar as dificuldades de implantar as ações planejadas 


\section{APÊNDICE G - ROTEIRO DE ENTREVISTA PRÓ-REITORA DE ENSINO}

\section{ENTREVISTA ABERTA COM A PRÓ-REITORA DE ENSINO}

1. O modelo de gestão aplicado ao ensino no IFPI, atende com êxito às finalidades e características dos IFs?

2. Quais são os desafios da gestão do IFPI, no atendimento às diversas modalidades de ensino?

3. Como o modelo de gestão dos IFs favorece o atendimento às demandas sociais e as peculiaridades regionais?

4. A verticalização do ensino, uma das características dos IFs, constitui um problema para a gestão de ensino do IFPI?

5. O que a organização didática representa pra PROEN?

6. A Pró-Reitoria de ensino dentro da estrutura organizacional do IFPI, tem sua autonomia de gestão garantida?

7. Na sua opinião, qual o principal papel da Pró- Reitoria de Ensino?

8. Na prática a Pró-Reitoria de ensino tem um papel mais relevante no andamento das ações do IFPI?

9. Como é verificada a qualidade do ensino na questão da associação entre teoria e prática tendo em vista o desenvolvimento local?

10. Quais as ações desenvolvidas pela gestão de ensino, que contemplam a atuação docente em busca da qualidade do ensino no IPFI?

11. Como as ações da DIREN são monitoradas e avaliadas?

12. Na sua percepção o que falta na estrutura da PROEN, para melhor desenvolver suas atividades? 


\title{
APÊNDICE H - ROTEIRO DE ENTREVISTA DIRETORA DE ENSINO
}

\author{
ENTREVISTA ABERTA COM A DIRETORA DE ENSINO
}

1. Relacione algumas limitações da estrutura organizacional dos IFs, estabelecida na Lei 11.892.

2. Quais são os desafios da gestão dos IFs, no atendimento às diversas modalidades de ensino?

3. Como o modelo de gestão dos IFs favorece 0 atendimento às demandas sociais e as peculiaridades regionais?

4. A verticalização do ensino, uma das características dos IFs, constitui em um problema para a gestão de ensino?

5. A DIREN dentro da estrutura organizacional dos IFs, tem sua autonomia de gestão garantida?

6. Na prática a DIREN de ensino tem um papel mais relevante no andamento das ações dos IFs?

7. Na sua opinião, qual o principal papel da DIREN? 